\title{
Dynamic musculoplasty, a new perspective for treatment of faecal incontinence
}

Citation for published version (APA):

Konsten, J. L. M. (1993). Dynamic musculoplasty, a new perspective for treatment of faecal incontinence. [Doctoral Thesis, Maastricht University]. Datawyse / Universitaire Pers Maastricht. https://doi.org/10.26481/dis.19931015jk

Document status and date:

Published: 01/01/1993

DOI:

10.26481/dis.19931015jk

Document Version:

Publisher's PDF, also known as Version of record

\section{Please check the document version of this publication:}

- A submitted manuscript is the version of the article upon submission and before peer-review. There can be important differences between the submitted version and the official published version of record.

People interested in the research are advised to contact the author for the final version of the publication, or visit the DOI to the publisher's website.

- The final author version and the galley proof are versions of the publication after peer review.

- The final published version features the final layout of the paper including the volume, issue and page numbers.

Link to publication

\footnotetext{
General rights rights.

- You may freely distribute the URL identifying the publication in the public portal. please follow below link for the End User Agreement:

www.umlib.nl/taverne-license

Take down policy

If you believe that this document breaches copyright please contact us at:

repository@maastrichtuniversity.nl

providing details and we will investigate your claim.
}

Copyright and moral rights for the publications made accessible in the public portal are retained by the authors and/or other copyright owners and it is a condition of accessing publications that users recognise and abide by the legal requirements associated with these

- Users may download and print one copy of any publication from the public portal for the purpose of private study or research.

- You may not further distribute the material or use it for any profit-making activity or commercial gain

If the publication is distributed under the terms of Article $25 \mathrm{fa}$ of the Dutch Copyright Act, indicated by the "Taverne" license above, 


\section{DYNAMIC MUSCULOPLASTY,}

A NEW PERSPECTIVE FOR TREATMENT

OF FAECAL INCONTINENCE 
CIP GEGEVENS KONINKLIJKE BIBLIOTHEEK, DEN HAAG

Konsten, Joseph Leonardus Maria

Dynamic musculoplasty, a new perspective for treatment of faecal incontinence/ Joseph Leonardus Maria Konsten. -

Maastricht : Universitaire Pers Maastricht. - Ill

Proefschrift Maastricht. -Met lit. opg, - Met

samenvalting in het Nederlands.

ISBN 90-5278-089-7

Trefw.: dynamische gracilisplastiek / incontinentie.

Boekverzorging: Datawyse | Universitaire Pers Maastricht

These studies were financially supported by The Ministry of Trade and Industry ("Stipt") and the Executive Health Insurance Board ("Ontwikkelingsgeneeskunde"), The Netherlands.

Publication of this thesis was supported by: "de stichting dr. ir. J.H.J. van de Laar", Medtronic Inc. and Synectics Medical. 


\section{DYNAMIC MUSCULOPLASTY, A NEW PERSPECTIVE FOR TREATMENT OF FAECAL INCONTINENCE}

\section{PROEFSCHRIFT}

ter verkrijging van de graad van doctor aan de Rijksuniversiteit Limburg te Maastricht, op het gezag van de Rector Magnificus, Prof. Mr. M.J. Cohen, volgens het besluit van het College van Dekanen,

in het openbaar te verdedigen

op vrijdag 15 oktober 1993 om 14.00 uur

$$
\text { door }
$$

Joseph Leonardus Maria Konsten

geboren te Heerlen op 1 april 1963

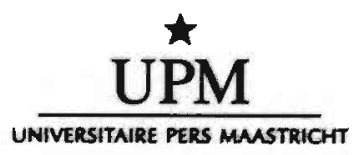




\section{Promotor:}

Prof. dr. P.B. Soeters

\section{Co-promotor:}

Dr. C.G.M.I. Baeten

Beoordelingscommissie:

Prof. dr. R.A. Janknegt (voorzitter)

Prof. dr. J.W. Arends

Prof. dr. E. Cavina (Universiteit van Pisa)

Dr. J.H.C. Kuypers (Katholieke Universiteit Nijmegen)

Prof. dr. R.W. Stockbrügger

Prof. dr. N.S. Williams (Universiteit van London)

To the memory of my father 
Parts of this thesis were published in the following joumals or are submitted:

I Baeten CGMI, Konsten J, Spaans F, Visser R, Habets AMMC, Bourgeois IM, Wagenmakers AJM, Soeters PB. Dynamic Graciloplasty for treatment of faecal incontinence. Lancet 1991; 338: 1163-5

2 Konsten J, Baeten CGMI, Dulk den K, Spaans F. Demonstration of the feasibility of implantation of a skeletal muscle pulse generator for fecal incontinence in a patient with an implanted unipolar DDD pacemaker. Pace 1992; 15: 825-30

3 Konsten J, Baeten CGMI, Spaans F. Havenith M. Soeters PB. Anale dynamische M. gracilisplastiek; een nieuwe chirurgische techniek voor de behandeling van fecale incontinentie. Nederlands Tijdschrift Voor Geneeskunde 1992; 136: 2178-82

4 Konsten J, Heineman E, Baeten CGMI. Gracilis muscle transposition for anal incontinence. J Pediatr Surg 1992; 27: 795-6 (correspondence)

5 Konsten J, Baeten CGMI, Mameren van H, Spaans F. Havenith MG, Soeters PB. Feasibility of stoma continence, using electrically stimulated rectus abdominal muscle in pigs. Dis Colon Rectum 1993; 36: 247-54

6 Konsten J, Baeten CGMI, Havenith MG, Oei TK. Evaluation of gracilis muscle transposition for faecal incontinence with magnetic resonance imaging. Eur J Radiology 1993: 16: 190-5

7 Konsten J, Baeten CGMI, Havenith MG, Soeters PB. Morphology of dynamic graciloplasty compared to the anal sphincter. Dis Colon Rectum (accepted)

8 Konsten J, Baeten CGMI, Spaans F, Havenith M, Soeters PB. Follow-up of anal dynamic graciloplasty for fecal continence. W J Surg (accepted)

9 Adang EMM, Engel GL, Konsten J, Baeten CGMI. Quality of life after dynamic graciloplasty for faecal incontinence, first results. Theor Surg (accepted)

10 Baeten CGMI, Konsten J, Heineman E, Soeters PB. Dynamic graciloplasty for anal atresia. J. Pediatr Surg (accepted)

11 Konsten J, Baeten CGMI, Havenith MG, Soeters PB. An animal model for treatment of faecal incontinence, using transposed and electrically stimulated skeletal muscle. (submitted) 


\section{CONTENTS}

1. Introduction 7

1.1 Faecal continence and incontinence; physiology and pathofysiology 8

1.2 Surgical treatment of faecal incontinence 13

1.3 New perspectives for treatment of faecal incontinence 15

1.4 Outline of the study 18

2. The feasibility of transposed skeletal muscles for treatment of faecal Incontinence 25

2.1 Anatomy and morphology of the anal sphincters 26

2.2 Topology and morphological characteristics of muscles suited for sphincteroplasty 28

2.3 Discussion 31

3 The feasibility of transposed and stimulated rectus muscle to serve as a sphincter in pigs 37

3.1 Introduction 38

3.2 Human cadaver dissections 40

3.3 Animal experimentation 41

3.4 Discussion 48

4 The feasibility of transposed and electrically stimulated sartorius muscle to serve as a sphincter in dogs 53

4.1 Introduction 54

4.2 Material and Methods 54

4.3 Results 57

4.4 Discussion 61

5. Anal dynamic graciloplasty 65

5.1 Introduction 66

5.2 Patients and methods 66

5.3 Results 70

5.4 Discussion 77

6. General discussion 85

Summary and conclusions $\quad 88$

Samenvatting en conclusies $\quad 91$

Acknowledgements 94

Curriculum vitae $\quad 96$ 
Chapter 1 INTRODUCTION 


\subsection{FAECAL CONTINENCE AND INCONTINENCE; PHYSIOLOGY AND PATHOPHYSIOLOGY}

\section{General attitude}

Bowel management is of great importance for the feeling of well-being but bowel habits vary from one individual to the other and are influenced by social and cultural circumstances (1). For example, in the United Kingdom and United States faecal continence is expected to be achieved by the end of the second year of life but in other parts of the world, the sixth birthday is considered normal $(2,3)$. The prevalence of faecal incontinence (involuntary loss of stools) has never been accurately assessed but may be between 0.5 and 1.5 percent of the general population (1). In our western society, anal incontinence, although not a life-threatening disease, can be a disabling disorder $(4,5)$. This justifies intensive research and an active approach to this condition.

\section{Faecal continence}

Faecal continence is the controlled balance between propulsive forces (peristaltic movements of the colon and rectum) and holding forces (the anal sphincters and the pelvic floor). The following anatomical structures (fig 1) are considered essential for faecal continence: (i) the muscle wall of the anorectum, (ii) the musculus sphincter ani internus, (iii) the musculus sphincter ani externus, (iv) the musculus levator ani and (v) the transitional epithelium of the anal canal (6). The control of this balance is achieved by an integration of autonomous and somatic nerves which control the anorectum.
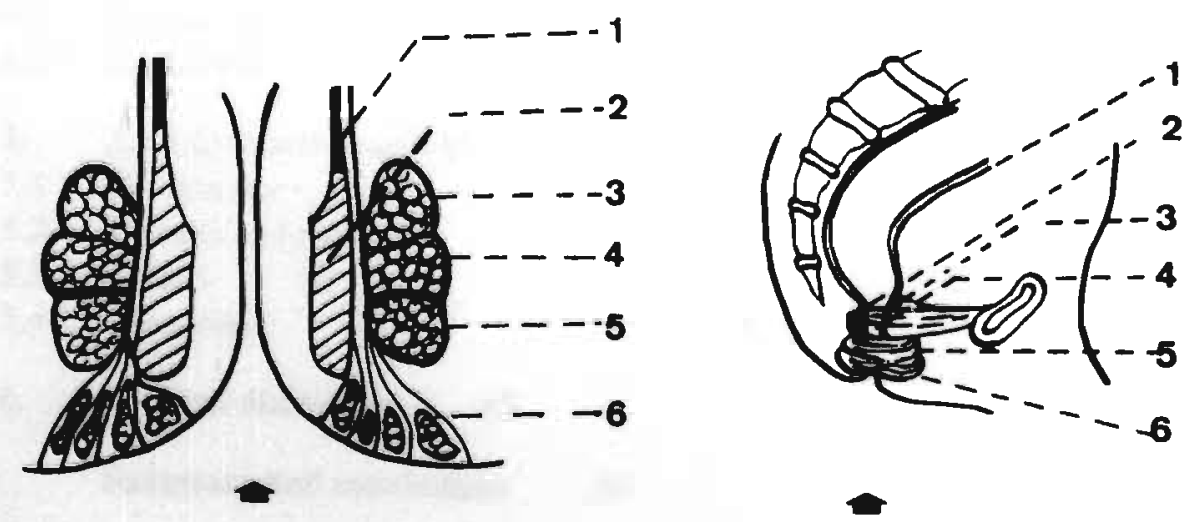

Figure 1, the muscles of the pelvic floor 1 = circular muscle of the rectum, 2 = internal anal sphincter, $3=$ puborectalis muscle, $4=$ deep extemal anal sphincter, $5=$ superficial external anal sphincter, $6=$ subcutaneous external anal sphincter. The arrow is indicating the opening of the anal canal. 
The autonomic innervated muscles of the rectal wall and the intemal anal sphincter receive their innervation from parasympathetic nerves arising from S2-S4 and from sympathetic nerves arising from the lower 6 thoracic and upper 2 lumbar segments of the spinal cord. Nociceptive information travels in both the parasympathetic and sympathetic nerves. It has been suggested that the sensation of rectal distension is conducted by the parasympathetic nerves and colonic distension by the sympathetic system (7).

The internal sphincter has a continuous muscle tone which is however, subdue to cyclic activity changes (8). Recently, it became clear that the nonadrenergic, noncholinergic neurotransmitter of the intramural nerves which causes relaxation is nitric oxide (9). The autonomic extrinsic innervation is more controversial but most likely compromises both sympathetic as well as parasympathetic supply (10).

The musculus sphincter ani externus and levator ani are innervated by somatic nerves. Branches arise from $2 \mathrm{nd}, 3 \mathrm{rd}$ and 4 th sacral nerves and join the pudendal nerve whereas the musculus puborectalis also receives a direct branch from S3-4 (11). The sensation of the anal canal which allows detection of faeces is mediated by the inferior branches of the pudendal nerve $(12,13)$.

The holding forces of continence (internal anal sphincter, external anal sphincter and puborectal muscle) produce a high pressure zone providing a mechanical barrier which closes the anal canal at rest because these three muscles are tonically active (14-17). The proportion with which these structures contribute to this high pressure zone is difficult to estimate as the structures overlap anatomically.

The anorectal angle which is due to impression of the puborectal muscle into the anal canal was once thought to be responsible for faecal continence (18). Continence could be achieved as a result of the normal abdominal pressure which causes sealing of the anal canal by the upper frontal rectal wall. Another explanation may be that the normal abdominal pressure compresses the upper anal canal above the pelvic floor muscles which creates a flutter valve. But, these hypotheses have been challenged and the described mechanisms could not be demonstrated during physiological testing (19). However, an acute angle might contribute to continence for solid faeces.

\section{Mechanisms of faecal continence}

The empty rectum will respond to stool arrival by distension which causes a decrease of the internal sphincter tone (the rectoanal inhibitory reflex) (15) which is conducted via the intrinsic nerves of the gut (intramural pathway) (20). 
Miller et al demonstrated that such a relaxation of the internal anal sphincter allows the rectal contents to contact the anal canal sensory epithelium (anorectal sampling reflex $)(13,21,22)$. Pemberton and Kelly hypothesized that when delay of defaecation is required, the external anal sphincter can contract (above its tonically active state) and return the faeces into the rectum. Consequently, the anal resting tone will be restored, the muscle of rectal wall adapts to the larger volume and the urge to defaecate disappears. However, continuous rectal distension will induce an external sphincter inhibition and the need for defaecation becomes more urgent (20).

As outlined before, control of continence requires anatomical structures like the muscle wall of the anorectum, the musculus sphincter ani internus and externus, the musculus levator ani and the sensory epithelium of the anal transitional zone (6). Reflex arches, voluntary contractions and consciousness are important to control these structures but none of the described components is responsible for continence all by itself. In addition, the venous plexus haemorrhoidalis acts as a corpus cavernosum and occlude the anal canal tightly by swelling inside the contracted sphincter muscles $(23,24)$.

Other factors like for example stool volume and consistency are important because liquid stools may overload the sphincter mechanism. A non-distending rectum induces a reduction of the rectal compliance which also can overload the sphincter mechanism.

On the other hand, a low anterior resection for rectal cancer and reduction of the distension capacity of the rectum will scarcely induce incontinence. Incision of the internal anal sphincter (for anal fissure) may incidentally cause incontinence but does normally not compromise continence (23). Patients with anal atresia can have normal continence after surgical repair despite the absence of the internal anal sphincter (6).

Damage to the innervation of the pelvic floor muscles after childbirth does not always cause incontinence. Excision of the rectum and the anal transitional zone (for ulcerative colitis or familiar polyposis) in restorative ileo-anal pouch anastomosis can result in acceptable continence in these patients $(25,26)$. In patients with incomplete spinal cord transection, resting EMG activity may be normal in the external anal sphincter and this activity increases during coughing (27). As a consequence, continence may be normal in these patients. The previously described conditions and operations do not always initiate incontinence because the described anatomical structures and their control mechanisms are capable to compensate for impaired function of one or several components (23). 


\section{Farcal incontinence}

Faecal incontinence is a disturbed balance between propulsive forces and holding forces. Consequently, the voluntary control of stool is lost. The implications of this disorder are restrictions in social life, giving rise to isolation and incapacity to work $(5,28)$. The prevalence of anal incontinence increases with age and has been reported to be 4.2 per 1000 (age 15-64 years) and 10.9 per 1000 in men (age over 65 years) in the United Kingdom. These numbers are respectively 1.7 and 13.3 in women (29). In hospitalized elderly patients the prevalence may be as high as, 13 to $47 \%(30,31)$. The economic consequences of this disorder are unknown (14). The etiology of incontinence may consist of diseases which overload sphincter function such as (infectious) diarrhoea, inflammatory bowel disease, the irritable bowel syndrome, short gut syndrome, laxative abuse, radiation enteritis and a non distending rectum. Overflow may be caused by faecal impaction and rectal neoplasms.

Other reasons for faecal incontinence may be interference with sphincter function (the holding forces) itself, either due to damage of the innervation or direct damage of the anal sphincter muscle. Examples of direct sphincter damage are: fistula surgery, obstetric injury and anal atresia (32). Childbirth may induce the so called primary neurogenic incontinence in which the pudendal nerves are stretched and damaged (pudendopathy) (33). Straining, prolapse and the descending perineum syndrome may also cause pudendopathy and therefore induce denervation of the pelvic floor muscles (34).

Haemorrhoidectomy in patients with minor perineal descent implicates impairment of two components of the holding forces and causes incontinence (35). Other causes of neurogenic dysfunction are spinal cord injury, cerebrovascular accidents, surgical damage to the central or peripheral nervous system and myelomeningocele (36). In some cases (e.g. after childbirth and in anal atresia) incontinence is generated by a combination of neurogenic and anatomical disorders. Patients with complete supraconal cord lesions are unable to contract the external anal sphincter at will and have a complete loss of rectal sensibility. In addition, these spinal cord patients have pathological responses to balloon inflation such as exaggerated rectal contractions and sustained anal sphincter relaxations. The latter might suggest that the rectal contractile response and the rectoanal inhibitory reflex are normally suppressed by descending pathways. Cortical inhibition of the external sphincter is mandatory for defaecation; loss of suppression of spinal and enteric reflexes and loss of control of the extemal sphincter explain the unpredictable reflex defaecation in these patients (37). 


\section{Clinical evaluation}

A careful medical history and a meticulous examination can reveal the cause of incontinence in most patients (14). A detailed questionnaire can assess the degree and frequency of faecal incontinence and therefore the effect upon quality of life. Such questionnaires can be used to reveal the etiology of incontinence and to evaluate the efficacy of various treatment modalities (38).

A digital rectal examination provides useful information about the basal sphincter tone (at rest) and the squeeze sphincter tone (during a voluntary contraction of the external anal sphincter). Patients with a weak sphincter strength can be discriminated from patients with a strong sphincter strength (during rest and a voluntary contraction) by simple recto-anal digital examination (39). In addition, rectal examination may reveal information about the function of the puborectal muscle and the stool consistency (14).

\section{Physiologic testing}

Continence is a function of various components (40). As a consequence different test are required to assess the (patho-)physiological mechanisms. We routinely use three tests: (i) anal manometry (ii) neurophysiological evaluation (electromyography of the external anal sphincter and assessment of the pudendoanal reflex and (iii) defaecography. Other tests such as endoscopy, bowel transit times, proctosigmoidoscopy, colonoscopy can be performed for specific indications (14).

\section{Anorectal manometry}

Anal sphincter strength can be measured, using anorectal manometry. During such a test, a probe (microballoon, waterperfused catheter or microtransducer) is introduced into the rectum and withdrawn into the anal canal in small increments (station pull through) or withdrawn continuously (continuous pull through). The resting (basal) anal canal pressure and the pressure due to a voluntary contraction (squeeze) can be measured during these pull troughs (41-45).

The inflation of a balloon (mounted on a catheter) into the rectum with increasing volumes of air can be used to measure the rectal sensibility and capacity. The distension of the rectum by a balloon will cause rectal contractions, internal anal sphincter relaxation and external anal sphincter contraction. Therefore, blowing up the balloon can be used to evaluate the rectal sensibility and capacity, the recto-anal inhibition reflex and the recto-anal contractile reflex. Unfortunately, there is no accepted standardized method of performing anorectal manometry and no strict relationship with the patients complaints (46). 


\section{Neurophysiological assessment}

Electromyography of the external anal sphincter during rest and squeeze can show the recruitment of the motor units. In addition, it may reveal pathological signs such as fibrillations, positive sharp waves and complex motor unit potentials which suggests denervation and reinnervation $(47,48)$. The integrity of the motor unit (anterior hom cell, axon, motor end plates and external sphincter muscle fibers) can be assessed by using the classical anal spinal reflex in which the perianal skin is pricked and the anal sphincter contracts (49). Reflex reactions of the external anal sphincter can be found also by electrical stimulation of the dorsal nerve of the penis or clitoris (pudendoanal reflex) (50). The combination of electrical stimulation and electromyographical assessment of the anal sphincter reaction allows measurements of; (i) the latency, (ii) amplitude, (iii) duration of the pudendoanal reflex and (iv) mean motor unit potential duration (50). Pudendal neuropathy can be evaluated in detail if the pudendal nerve terminal motor latency is measured as described by Kiff and Swash $(51,52)$,

\section{Defaecography}

Defaecography is a dynamic radiologic study of continence and defaecation. Barium paste is installed into the rectum and while the patients is seated on a water filled commode, $\mathrm{X}$-ray images or a video tape of the pelvis can be recorded. During the examination, the shape of the rectum and the function of the pelvic floor muscles can be studied during squeeze, rest and straining. The perineal descent, the anorectal angle and rectal evacuation can be studied simultaneously. Defaecography is especially suited to detect rectal abnormalities as prolapse and rectoceles. The ability to retain the contrast provides additional information about continence (53-55).

It remains questionable if these tests are mandatory. Most information can be obtained from a careful history and anorectal examination. However, anorectal physiological testing may be used for research purposes $(14,38)$.

\subsection{SURGICAL TREATMENT OF FAECAL INCONTINENCE}

The aim of incontinence treatment is when possible to cure the primary disorder. Conservative measurements such as dietary changes and constipating agents should be tried first before considering surgery for faecal incontinence. When an intact but malfunctioning pelvic floor is present, patients can and should be treated conservatively by means of biofeedback training $(56,57)$. During this conservative treatment modality, the patient is trained to contract the external anal sphincter and the muscles of the pelvic floor in response to the inflation of an intrarectal balloon with decreasing volumes of air. The outcome of biofeed- 
back is not associated with an increase of the anal resting pressure but with an increased ability to recognize rectal distension which precedes defaecation and augmenting the holding forces with a voluntarily contraction of the external sphincter (57).

Surgery should be performed when sphincter function is insufficient, and when the pelvic floor and its function needs to be restored. Such procedures consist of an effort to reconstruct the anal sphincters and/or the pelvic floor by means of reefing and overlapping (58). Faecal incontinence after delivery has been reported to improve after anal repair (59). Long standing anal incontinence may be treated with postanal repair $(60)$. The aim of postanal repair is to restore the anorectal angle by reefing of the pelvic floor muscles. However, a reefed puborectal muscle results in an outlet obstruction and in most cases the muscle fibers will be denervated, resulting in disappointing clinical results. In addition, the anorectal angle may not be associated with continence at all. Therefore, this procedure is reported to be only partially successful and long-term results have been disappointing. In a recent study, 60 of 116 patients continued to wear pads after postanal repair (61).

An extensive loss of anal sphincter muscle can be replaced with a new sphincter to restore the holding forces. Examples of these artificial sphincters are a Thiersch wire and an inflatable cuff $(62,63)$. More exceptional techniques and devices have been used to achieve stoma continence as a stoma is always lacking a sphincter mechanism. Examples of such stoma sphincters are autotransplantation of the pylorus, the Erlangen magnetic device and porcine valves (64-67).

However, artificial material in cont ct with the bowel wall may cause infection, decubital ulcer and perforation (68). Schmidt proposed the use of smooth muscle to reconstruct an anal sphincter but such a sphincter does not resemble the autonomic internal anal sphincter or the external anal sphincter (69). Smooth muscle transposition may produce a continuous outlet obstruction rather than reliable continence (including true voluntary defaecation).

As a consequence, other approaches to reconstruct the sphincter have been employed, including the use of autologous material such as the fascia lata plasty and skeletal muscle transposition with undisturbed nerve and vascular supply like the gluteus transposition and graciloplasty (70-73). Even denervated muscle grafts have been used to restore the anorectal angle (74).

The most widely employed transposition procedure is the graciloplasty (75-78). Because the gracilis is a skeletal muscle such a graciloplasty needs to be contracted voluntarily during a prolonged period of time to achieve faecal 
continence. However, a sustained voluntary contraction is difficult to maintain which explains why this technique fails in the majority of cases (79). Dickson and Nixon suggested in 1968 that a continuous contraction of a graciloplasty can be achieved with stimulation via implanted electrodes, providing a new high pressure zone in the anal canal which is essential for faecal continence (80). However, stimulation with implanted devices was not technically feasible and the effects of electrical stimulation upon muscle properties were unknown at that time.

\subsection{NEW PERSPECTIVES FOR TREATMENT OF FAECAI, INCONTINENCE}

\section{Musculature}

The ability to contract is possessed by most human cells. However, the contraction force is developed at best by muscle cells. These cells can be divided into smooth and striated fibers. Smooth or visceral muscle cells are under autonomic control whereas striated muscle fibers are under voluntary control (81).

\section{Smooth muscle}

Smooth muscle cells are present in the wall of the most hollow organs, such as the bowel, uterus, bladder and vascular system. Apparently, the smooth muscle cell function is to change the hollow organ diameter. Slow muscle cells contract slowly but are capable of a continuous contraction. In case of the internal (smooth) anal sphincter, the continuous contraction is due to intrinsic myogenic as well as autonomic neurogenic properties $(17,82)$.

\section{Skeletal muscle}

The oldest classification of skeletal muscles was based on appearance (83). For example, the soleus muscle appears to be red and the lateral head of the gastrocnemius muscle is white (84). Later, it was recognized that muscle fibers are not entirely uniform and that a skeletal muscle contains different types of fibers. The majority of fibers composing the gastrocnemius muscle were described as white and of soleus muscle as red.

Historically, most histochemical studies are based upon a myosin ATPase reaction (after incubation at different $\mathrm{Ph}$ values) which allows distinction of muscle fibers as type I or type II $(85,86)$. Nowadays, it is known that muscles in man consist of a mixture of different fiber-types in a mosaic pattern and these fibers are divided in different groups, according to morphological, physiological and enzymatic properties (87). Physiologists categorize fibers according to the time course of the maximal twitch as being fast twitch, fatigue prone and slow 


\begin{tabular}{|c|c|c|c|}
\hline & & TYPE I & TYPE II \\
\hline \multirow[t]{4}{*}{ morphology } & color & red & white \\
\hline & fiber size & small & large \\
\hline & capillarization & high & low \\
\hline & mitochondria & many & few \\
\hline \multirow[t]{5}{*}{ physiology } & contraction time & slow & fast \\
\hline & fatiguability & fatigue-resistant & fatigue-prone \\
\hline & power output & low & high \\
\hline & fusion frequency for tetanic & & \\
\hline & contraction & low & high \\
\hline \multirow[t]{3}{*}{ biochemistry } & aerobic oxidative capacity & high & low \\
\hline & $\begin{array}{l}\text { glycolytic capacity } \\
\text { capacity of sarcoplasmatic }\end{array}$ & low & high \\
\hline & reticulum to sequester $\mathrm{Ca}^{2+}$ & low & high \\
\hline
\end{tabular}

twitch, fatigue resistant $(85,86)$. Biochemists classify muscle fibers according to metabolic properties, such as having a high activity of oxidative enzymes and a low glycolytic capacity or as having a high activity of anaerobic enzymes and high glycolytic capacity (85-89)(table I).

At the level of a motor unit, target muscle fibers of phasic active neurons are mostly fast twitch and fatigue-prone whereas muscle fibers of postural active neurons are mostly slow twitch and fatigue resistant (90). Slow twitch, fatigue resistant muscle fibers are referred to as type I whereas fast twitch, fatigue prone muscle fibers are referred to as type II $(84,91)$. These type II fibers can be divided into $\mathrm{A}, \mathrm{B}$ and $\mathrm{C}$ depending upon preincubation at different $\mathrm{pH}$ values (91). A somatic voluntary muscle consists of fibers (cells) which contain myofibrils. These myofibrils contain thin filaments composed of actin, tropomyosin and troponin and thick filaments which are composed of myosin. Myosin is an enzyme (ATPase) augmenting ATP release, essential for contraction. Division of muscle fibers into categories, depending upon myosin characteristics may be logical, but myosin is a hexameric structure composed of two heavy and four light chains. All these chains have various isoforms and even different types of tropomyosin and troponin have been described. Type I and type II fibers reflect a range of fiber populations with variations in their type of 
proteins in a wide continuing range. Therefore, classification of muscle fibers in different groups is artificial (89).

We used the common division in type I, slow twitch, fatigue resistant and type II, fast twitch, fatigue prone muscle fibers because a correlation exists between biochemical, physiological and morphological characteristics $(86,89)$. Such a division can be based upon an immunohistochemical staining-method which can be routinely performed on formalin embedded sections (92).

\section{Skeletal muscle innervation and transformation}

Buller and Eccles transferred the nerve of a slow twitch muscle to a fast twitch muscle in cats and vice versa (93). This induced a transformation of the cross-innervated muscle fibers with regard to physiological, histochemical and biochemical properties and isomyosin spectrum (89,93-95). Apparently, the motor neuron determines the characteristics of the innervated muscle fibers within one motor unit (90).

If a skeletal muscle is used to replace the anal sphincter, a tonically active neo-sphincter is required which should be fatigue resistant to imitate normal anal sphincter function. The gracilis muscle lacks these characteristics and is intrinsically unsuitable for this function. Salmons and Vrobva demonstrated in cats that transformation from fatigue prone to fatigue resistant fibers can be gained by electrical stimulation of the innervating nerve (96). These findings have been clinically used for the correction of scoliosis and for muscle-assist in cardiac failure (97-100). In the latter procedure, the latissimus dorsi muscle is wrapped around the heart and electrically stimulated with implanted electrodes to improve cardiac performance.

In graciloplasty, gracilis muscle is wrapped around the anal canal with intact innervation and vascularization to replace an absent or severely damaged anal sphincter (75-79). However, the anal sphincter is known to be continuously active whereas gracilis muscle is largely a fast twitch, fatigue prone muscle $(8,15,101-103)$. Electrical stimulation of graciloplasty or another transposed skeletal muscle may provide such a muscle with sphincter properties, including sustained contractions. As a consequence, faecal continence may be achieved. The feasibility was demonstrated by Baeten et al. in a case report (for gracilis muscle) in 1988 (104) and confirmed for sartorius muscle in dogs by Hallan et al. in 1990 (105). The aim of this thesis is to study such a neosphincter. 


\subsection{OUTLINE OF THE STUDY}

Aim of the thesis

Surgical techniques, using transposed skeletal muscle allow the construction of a neo-anal sphincter. However, as outlined before, skeletal muscle is not able to contract continuously, a capacity which is mandatory for faecal continence. The aim of this thesis was to assess if electrical stimulation of transposed skeletal muscle enables such a structure to function as a new anal sphincter. In addition, if this is the case, can such a neo-sphincter also be used to achieve stoma continence?

The research described in this thesis can be subdivided as follows: First, anatomy and morphology of the anal sphincters is described. The same was done for 4 muscles (rectus, sartorius, gluteus and gracilis) potentially suitable for sphincter creation (chapter 2). Second, the feasibility of transposed and electrically stimulated muscles as a new sphincter around an isolated loop of intestine (Thiry-Vella loop) in pigs is reported (chapter 3). Third, a skeletal muscle from the upper-leg (sartorius) was used to construct a sphincter around a Thiry-Vella loop in dogs (chapter 4).

Finally, the feasibility of a neo-anal sphincter in patients with faecal incontinence was assessed, using a transposed and electrically stimulated muscle from the upper leg (anal dynamic graciloplasty) (chapter 5). 


\section{REFERENCES}

I Mandelstam DA. Faecal incontinence. In: Henry MM, Swash M (eds). Coloproctology and the pelvic floor: pathofysiology and management $\left(1^{c}\right.$ edition). London: Butterworths 1985; 217-21

2 Cook RCM. Treatment: neonatal and paediatric incontinence. In: Henry MM, Swash M (eds). Coloproctology and the pelvic floor: pathofysiology and management $\left(2^{\circ}\right.$ edition). London: Butterworths 1992; 289-98

3 Whiting J, Child Il (eds) Child training and personality. New Haven: Yale University Press 1953

4 Corman ML. The management of anal incontinence. Surg Clin North Am 1983; 63: 177-91

5 Leigh RJ, Tumberg LA. Faecal incontinence: the unvoiced symptom. Lancet $1982 \mathrm{i}$ : 1349-51

6 Langenmeijer RAThM, Molenaar J. Defaecation problems in children: anatomy, physiology and pathophysiology of the defaecation mechanism. Neth J Surg 1991; 43: 208-12

7 Goligher JC, Hughes ESR. Sensibility of the rectum and colon. Its role in the mechanism of continence. Lancet 1951; i: 543-7

8 Enck P. Eggers E, Koletzko S, Erckenbrecht JF. Spontaneous variation of anal "resting" pressure in healthy humans. Am J Physiol 1991; 261: G823-6

9 O'Kelly TJ, Brading AF, Mortensen NJ. Inhibitory neurotransmission in the human internal anal sphincter: the role of nitric oxide. Dis Colon Rectum 1992; 35 : P42

10 Speakman CTM, Kamm MA. The internal anal sphincter-new insights into faecal incontinence. Gut 1991; 32: 345-6

11 Percy JP, Neill ME, Swash M, Parks AG. Electrophysiological study of motor nerve supply of the pelvic floor. Lancet 1981 ; i: 16-7

12 Gunterberg B, Kewenter J, Petersén I, Stener B. Anorectal function after major resections of the sacrum with bilateral or unilateral sacrifice of sacral nerves. Br J Surg 1976; 63: $546-54$

13 Duthie $\mathrm{HL}$, Bennet RC. The relation of sensation in the anal canal to the functional anal sphincter: a possible factor in anal continence. Gut $1963 ; 4: 179-82$

14 Madoff RD, Williams JG, Caushasj PF. Current concepts: Fecal continence. N Eng J Med 1992; 326: 1002-7

15 Govers WR. The autonomic action of the sphincter ani. Proc R Soc London 1887; 26: 77-84.

16 Floyd WF, Wallis EW. Electromyography of the sphincter ani extemus in man. Joumal of Physiology 1953; 122: 599-609

17 Frenckner B, Euler CHRV. Influence of pudendal block on the function of the anal sphincters. Gut 1975; 16: 482-9

18 Parks AG, Porter NH, Hardcastle JD. The syndrome of the descending perineum. Proc Roy Soc Med 1966; 59: 477-82

19 Bannister JJ, Gibbons C, Read NW. Preservation of incontinence during rises in intra-abdominal pressure: is there a role for the flap valve? Gut 1987; $28: 1242-5$

20 Pemberton JH, Kelly KA. Achieving enteric continence: principles and applications. Mayo Clin Proc 1986; 61: 586-99 
21 Miller R, Bartolo DCC, Cervero F, McC Mortensen NJ. Anorectal sampling: a comparison of normal and incontinent patients. Br J Surg 1988; 75: 44-7

22 Miller R, Lewis GT, Bartolo DCC er al. Sensory discrimination and dynamic activity in the anorectum: evidence using a new ambulatory technique. $\mathrm{Br} \mathrm{J}$ Surg 1988; 75 : 1003-7

23 Baeten CGMI. Physiology. In: Haemorrhoids, evaluation of methods of treatment (thesis). Maastricht: Van Gorcum-Assen 1985; 12-22

24 Stelzner P. Kontinenz, Superkontinenz und Inkontinenz in Anorektalbereich. Dtsch Med Wschr 1965; 90: 2275-81

25 Taylor BM, Bearth RW, Dozois RR, Kelly KA, Wolff BG, Ilstrup DM. The endorectal ileal pouch-anal anastomosis: current clinical results. Dis Colon Rectum 1984; 27 : 347-50

26 Oresland T, Fasth S, Akervall S, Nordgren S, Hultén L. Manovolumetric and sensory characteristics of the ileoanal J pouch compared with healthy rectum Br J Surg 1990; 77: 803-6

27 Frenckner B. Function of the anal sphincters in spinal man. Gut 1975; 16: 638-44

28 Henry MM, Swash M, Philips RKS, Thomson JPS, Corman ML, Williams NS, Kuypers HC, Bleijenberg G, Snooks SJ, Cook RCM. Faecal incontinence. In: Henry MM, Swash $M$ (eds). Coloproctology and the pelvic floor: pathofysiology and management $\left(2^{e}\right.$ edition. London: Butterworths 1992; 257-305

29 Thomas TM, Egan $\mathrm{M}$, Walgrove $\mathrm{A}$ et al. The prevalence of faecal and double incontinence. Comm Med 1984; 6: 216-20

30 Clarke $\mathrm{M}$, Hughes $\mathrm{AO}$, Dodd $\mathrm{KJ}$ et al. The elderly in residental care: patterns of disability. Health trends 1979; 11: 17-20

31 Mclaren SM, McPherson FM, Sinclair F, Ballinger BR. Prevalence and severity of incontinence among hospitalised, female psychogeriatric patients. Health Bull (Edinb) 1981; 39: 157-61

32 Durham Smith $\mathrm{E}$. The bathwater needs changing, but don't trow out the baby: an overview of anorectal anomalies. J Pediatr Surg 1987; 22: 335-84

33 Snooks SJ, Swash M, Setchell M, Henry MM. Injury to the innervation of pelvic floor musculature in childbirth. Lancet 1984; ii: 546-50

34 Womack NR, Morrison JFB, Wiliams NS. The role of pelvic floor denervation in the aetiology of ideopathic feacal incontinence. Br J Surg 1986; 72: 404-7

35 Read NW, Bartolo DCC, Read MG, Hall J, Haynes WG, Johnson AC. Differences in anorectal manometry between patients with haemorrhoids and patients with the descending perineum syndrome: implications for management. Br J Surg 1983; 70: 656-9

36 Swash M, Snooks SJ. Slowed motor conduction in lumbosacral nerve roots in cauda equina lesions. J Neurology Neurosurgery and Psychiatry. 1986; 49: 808-16

37 MacDonagh R, Sun WM, Thomas DG, Smallwood R, Read NW. Anorectal function in patients with complete supraconal spinal cord lesions. Gut 1992; 33: 1532-38

38 Jorge JMN, Wexner SD. Etiology and management of faecal incontinence. Dis Colon Rectum 1993; 36: 77-97

39 Hallan RI, Marzouk DEMM, Waldron DJ, Womack NR and Williams NS. Comparison of digital and manometric assessment of anal sphincter function. Br J Surg 1989; 76: 973-75

40 Womack NR, Williams NS, Holmfield JHM, Morrison JFB, Simpkins KC. New method for the dynamic assessment of anorectal function in constipation. Br J Surg 1985; 72: $994-8$ 
4) Keighley MRB, Henry MM, Bartolo DCC. McC Mortensen NJ. Anorectal physiology measurement: report of a working party. Br J Surg 1989; 76: 356-7

42. Karulf RE, Coller JA, Bartolo DC. Anorectal physiology testing: a survey of availability and use. Dis Colon Rectum 1991; 34: 464-8

43 Schouten WR, Vroonhoven van TJ. A simple method of anorectal manometry. Dis Colon Rectum 1983; $26: 271-4$

44 Hiltunen KM. Anal manometric findings in patients with anal incontinence. Dis Colon Rectum 1985; $28: 925-8$

45 Felt-Bersma RJF, Meuwissen SGM. Anal manometry. Int J Colorect Dis 1990; 5: $170-3$

46 Felt Bersma JF, Klinkenberg Knol EC, Meuwissen SGM. Anorectal function investigations in incontinent and continent patients: differences and discriminatory value. Dis Colon Rectum 1990; 33: 479-85

47 Bartolo DCC, Jarrat JA, Read MG. The use of conventional electromyography to assess extemal anal sphincter neuropathy in man. J Neurosurg Psych 1983; 46: 1115-8

48 Wexner SD, Marchetti F, Salanga VD, Corredor C, Jagelman DG. Neurophysiologic assessment of the anal sphincters. Dis Colon Rectum 1991: 34: 606-12

49 Bors E, Blinn KA. Bulbocavemosus reflex. J Urol 1959; 82: 128-30

50 Smith AN, Varma JS. The latency of the pudendo-anal reflex in man. J Physiol 1984; 360: 49P

51 Varma JS, Smith AN. Anal reflexes. In: Henry MM, Swash M (eds). Coloproctology and the pelvic floor: pathofysiology and management $\left(2^{e}\right.$ edition). London: Butterworths 1992; 207-19

52 Kiff ES, Swash M. Slowed conduction in the pudendal nerves in idiopathic (neurogenic) faecal incontinence. Br J Surg 1984; 71: 614-6

53 Mahieu P, Pringot J, Bodart P. Defecography I: Description of a new procedure and results in normal patients. Gastrointest Radiol 1984; 9: 247-51

54 Mahieu P, Pringot J, Bodart P. Defecography II: Contribution to the diagnosis of defeacation disorders Gastrointest Radiol 1984; 9: 253-61

55 Goei R. Anorectal function in patients with defaecation disorders and asymptomatic subjects. Radiology 1990; 74: 121-3

56 Wald A. Biofeedback for neurogenic fecal incontinence: rectal sensation is a determinant of outcome. J Pediatr Gastroenterol Nutr 1983; 2: 302-6

57 Miner PB, Donnelly TC, Read NW. Investigation of mode of action of biofeedback in treatment of fecal incontinence. Dig Dis Sci 1990; 35: 1291-8

58 Keighly MRB, Fielding JWL. Managment of faecal incontinence and results of surgical treatment. Br J Surg 1983; 70: 463-4

59 Fang DT, Nivatsongs S, Vermeulen FD, Herman FN, Goldberg SM, Rothenberger DA. Overlapping sphincteroplasty for acquired anal incontinence. Dis Colon Rectum 1984; 27: $720-2$

60 Scott ADN, Henry MM, Philips RKS. Clinical assessment and anorectal manometry before postanal repair: failure to predict outcome. Br J Surg 1990; 77: 628-9

61 Yoshioka K, Keighly MRB. Critical assesement of the quality of continence after postanal repair for faecal incontinence. Br J Surg 1989; 76: 1054-7

62 Gabriel WB. Thiersch procedure for anal incontinence. Proc Roy Soc Med 1948; 41 : 467-8

63 Christiansen J, Sparso B. Treatment of anal incontinence by an implantable prosthetic anal sphincter. Ann Surg 1992; 215: 383-6 
64 Tenney JB, Eng M, Graney MJ. The quest for continence. Dis Colon Rectum 1978; 21 : 522-33

65 Khubchandani IT, Trimpi HD, Sheets JA, Stasik JJ, Balclavage CA. The magnetic stoma device, a continent colostomy. Dis Colon Rectum 1981; 24: 344-50

66 Centeno Neto AAC, Veyrac M, Briand D, Spilotis J, Saint Aubert B, Joyeux H. Autotransplantation of the pylorus sphincter at the terminal abdominal colostomy: experimental study in dogs. Dis Colon Rectum 1991; 34: 874-9

67 Kock NG. Continent ileostomy. Arch Surg 1969; 99: 223-31

68 Vonsangnak V, Varma JS, Smith AN. Reappraisal of Thiersch's operation for complete rectal prolapse. J Roy Coll Surg (Edinburgh) 1985; 30: 185-7

69 Schmidt E. Die chirurgische Behandlung der analen Inkontinenz, mittels freitransplantierter autologer, körpereigener Darmmusckulatur. Chirurg 1978; 49: 320-1

70 Hentz VR. Construction of a rectal sphincter using the origin of the gluteus maximus muscle. Plast Reconstr Surg 1982; 70: 82-5

71 Cavina E, Seccia M, Evangelista G. Neo-sphincter and neo-stomy. New surgical vieuws for myoelectric stimulated continence. A clinical experience. Preliminary report. Am J Proctol Gastroenterol Colon Rectal Surgery 1982; 33: 16-9

72 Starke J, Braun J, Gruwez J, Schumpelick V. Transposition der Musculus glutaeus maximus zum Sphincterersatz, bei analer Inkontinenz. Chirurg 1992; 63: 56-61

73 Pearl RK, Prasad ML, Nelson RL, Orsay CP, Abcarian H. Bilateral gluteus maximus transposition for anal incontinence. Dis Colon Rectum 1991; 34: 478-81

74 Hakelius L. Free autogenous muscle transplantation in two cases of total anal incontinence. Acta Chir Scand 1975; 141: 69-75

75 Pickrell KL, Broadbent TR, Masters FW, Metzger JT. Construction of a rectal sphincter and restoration of anal incontinence by transplanting gracilis muscle: a report of four cases in children. Ann Surg 1952; 135: 853-63

76 Leguit P.Jr, Baal van JG, Brummelkamp WH. Gracilis muscle transposition in the treatment of fecal incontinence. Long term follow-up and evaluation of anal pressure recordings. Dis Colon Rectum 1985; 28: 1 -4

77 Yoshioka K, Keighly MRB. Clinical and manometric assesment of gracilis muscle transplant for fecal incontinence. Dis Colon Rectum 1988; $31: 767-9$

78 Cormann ML. Follow up evaluation of gracilis muscle transposition for fecal incontinence. Dis Colon Rectum 1980; 8: 552-5

79 Christiansen B, Rasmussen $\varnothing \varnothing$, Sørenson M. Gracilis muscle transposition for faecal continence. Br J Surg 1990; 77: 1039-40

80 Dickson JAS, Nixon HH. Control by electronic stimulator of incontinence after operation for anorectal agenesis. J Pediatr Surg 1968; 3: 696-701

81 Smooth muscle contraction. In: Guyton AC (ed) Textbook of medical physiology ( $8^{\mathrm{e}}$ edition) Philadelphia: WB Saunders 1991; 87-95

82 Meunier P, Mollard P. Control of the internal anal sphincter (manometric study with human subjects). Pflugers Arch 1977; 370: 233-9

83 Needham DM. Red and white muscle. Physiol Rev 1926; 6: 1

84 Brooke H, Kaiser KK. Muscle fibers types: how many and what kind. Arch Neurol 1970; 23: 369-79

85 Burke RE, Levine DN, Tsairis P. Zajac FE III: Physiological types and histochemical profiles in motor units of the cat gastrocnemicus. J Physiol (London) 1973: 234: 723-8. 
86 Burke RE, Levine DN, Zajac FE III, Tsairis P, Engel WK. Mammalisn motor units: physiological-histochemical correlation in three types in cat gastrocnemicus. Science 1971; 174: 709-12

87 Saltin B, Henriksson J, Nygaard E. Fibre types and metabolic potentials of skeletal muscle in sedentary man and endurance runners. Annals N. Y. Acad Sci 1977; 301: 3-29

88 Pette D. Invited review: neural control of phenotypic expression in mammalian muscle fibers. Muscle and Nerve 1985; 8: 676-89

89 Pette D. Vrobvá G. Adaptation of mammalian skeletal muscle fibers to chronic electrical stimulation. Rev Bicchem Pharmacol 1992; 120: 115-202

90 Freund $\mathrm{HJ}$. Motor unit and muscle activity in voluntary motor control. Physiol rev 1983; 63: $387-436$

91 Samaha FJ, Guth L, Albers RW. Phenotypic differences between the acomyosin ATPase of the three fiber types of mammalian skeletal muscle. Expl Neurol 1970; 27: 276-82

92 Havenith MG, Visser R, Schrijvers van Schendel JMC, Bosman FT. Muscle fiber typing in routinely processed skeletal muscle with monoclonal antibodies. Histochemistry 1990; 93: 497-9

93 Buller AJ, Eccles JC, Eccles RM. Interactions between motorneuronis and muscles in respect of the characteristic speeds of their responses. J Physiol (London) 1960; 150: 417-39

94 Mommaerts WFHM, Buller AJ, Seraydarian K. The modification of some biochemical properties of muscle by cross- innervation. Proc Natl Acad Sci (USA) 1969; 64: 128-33

95 Scréter FA, Luff AR, Gergely J. Effect of cross-reinnervation on physiological parameters and on properties of myosin and sarcoplasmic reticulum of fast and slow muscles of the rabbit. J Gen Physiol 1975; 66: 811-21

96 Salmons S, Vrobvá G. The influence of activity on some contractile characteristics of mammalian fast and slow muscles J Physiol (London) 1969; 210: 535-49

97 Bobechko WP, Herbert MA, Friedman HG. Electrospinal stimulation for scoliosis: current status. Orth Clin North Am 1986; 10: 927-41

98 Millner RWJ, Pepper JR. Cardiomyoplasty. BMJ 1991; 302: 1353

99 Glatz JFC, Vusse van der GJ, Havenith MG, Veen van der FH, Lucas CMHR, Penn OCKM, Wellens HJ. Adaptation of energy metabolism of canine latissimus dorsi muscle in response to chronic electrical stimulation. Pflügers Arch 1992; 420: 1-8

100 Chiu RCJ. Dynamic cardiomyoplasty: an overvieuw. Pace 1991; 14: 577-84

101 Schrøder HD, Reske Nielsen E. Fiber types in the striated urethral and anal sphincters. Acta Neuropathol (Berl) 1983; 60: 278-82

102 George BD, Patel J, Mginah P, Swash M, Watkins ES, Williams NS. Histological changes in the gracilis neosfincter muscle following long-term electrical stimulation. $\mathrm{Br}$ J Surg 1992; 79: 466

103 Konsten J, Baeten CGMI, Havenith MG, Soeters PB. Morphology of dynamic graciloplasty compared with the anal sphincter. Dis Colon Rectum 1992; 35: P45

104 Baeten C, Spaans F, Fluks A. An implanted neuromuscular stimulator for fecal continence following previously implanted gracilis muscle; report of a case. Dis Colon Rectum 1988; 31: 134-7

105 Hallan RI, Williams NS, Hutton MRE, Scott M, Pilot MA, Swash M, Koeze TH, Watkins ES. Electrically stimulated sartorius neosphincter: canine model of activation and skeletal muscle transformation. Br J Surg 1990; 77: 208-13 


\section{Chapter 2}

The feasibility of transposed skeletal muscles for treatment of faecal incontinence 


\subsection{ANATOMY AND MORPHOLOGY OF THE ANAL SPHINCTERS}

\section{Introduction}

The muscle wall of the anorectum, the internal anal sphincter, the external anal sphincter, the levator ani and the transitional epithelium of the anal canal are thought to be responsible for faecal continence (1). However, these structures are not equally important for continence. A rupture of the anal sphincter in childbirth will result in faecal incontinence. Surgical repair of the extemal anal sphincter restores continence (2). On the other hand, incision of the internal anal sphincter for a fissure does not result in incontinence (3).

The sphincter mechanism should be considered as a delicate balance between the internal and extemal sphincter (4). The relative contributions of the smooth internal sphincter muscle to the entire sphincter function have been assessed using bilateral pudendal block anaesthesia in order to paralyze the external anal sphincter muscle $(5,6)$. Frenckner and Euler demonstrated in their original study (using a bilateral pudendal block) that the internal anal sphincter contributes about $85 \%$ of the pressure in the anal canal at rest but only about $40 \%$ after a sudden substantial distension of the rectum. Both sphincter systems have an important function for continence. The internal anal sphincter is mainly responsible for the resting pressure while the external anal sphincter is partly responsible for the resting pressure as well as for the squeeze pressure (5). This chapter focuses on the anatomy of both sphincters and the morphology of the external anal sphincter.

\section{Anatomy of the anal canal}

The anal canal is approximately 4 to $4.5 \mathrm{~cm}$ long, starting at the level of the puborectal muscle and ending at the anal verge (7). The structure of the anal canal consists of two tubular parts; the inner circular part is the gut with the internal anal sphincter while the outer part consists of the funnel shaped levator ani and the circular extemal anal sphincters (8). The anal canal develops from the ectodermal proctodeum and fuses with the descending endodermal hindgut. The upper part of the anal canal is covered with mucosa while the inside of the lower part consists of epidermis. Between mucosa and epidermis, the transitional zone covers the anal canal for about $15 \mathrm{~mm}$. In the foetus a cloaca is formed, which is separated by downwards growing mesodermal tissue into an urogenital and intestinal compartment. Consequently, the cloacal membrane (which closes the cloaca) is split into an urogenital and anal membrane. These membranes open during the seventh (urogenital) and ninth (anal) week of embryologic 
development. Thus, all anorectal malformations are caused during the seventh and ninth weeks of development or before. At the same time ( $7^{\text {th }}$ and $9^{\text {th }}$ week) the levator ani and external anal sphincter develop.

The internal anal sphincter develops from the inner circular smooth muscle fibers (visceral mesoderm) which surround the gut. The internal sphincter has approximately a thickness of $5-10 \mathrm{~mm}$ and is $30-40 \mathrm{~mm}$ long in adults $(9,10)$. This sphincter is continuous with the circular muscle wall of the rectum (fig 1 , chapter 1).

The levator ani muscle consists of the pubococcygeus (with the puborectal muscle forming the puborectal sling), ileococcygeus and ischiococcygeus but variations are known $(11,12)$ The external anal sphincter is described classically into three parts; (i) the subcutaneous part surrounds the lowest part of the anal canal (ii) the superficial part is immediately above the subcutaneous part, it is attached to the perineal body in front and at the dorsal side to the coccyx forming the anococcygeal ligament (iii) the deep part surrounds the upper part of the anal canal and its fibers are associated with those of the puborectal sling $(13,14)$.

Goligher denied a clear separation in three parts (15) and more recently, no lamination of the sphincter could be revealed in 20 cadaver dissections (16). Other descriptions are known and describe the extemal anal sphincter as an one-part, two-part, or three-part striated skeletal muscle (17-18). These various descriptions may also reflect the well known individual variations. The normal thickness of the external anal sphincter is $10 \mathrm{~mm}$ and the length $30 \mathrm{~mm}(10)$. The innervation is from the inferior rectal branch of the pudendal nerve (S2 and 3) and may be the perineal branch of $S 4$ (16).

The vascularization of the anal canal and muscles of the pelvic floor is derived from the inferior mesenteric artery and the internal iliac artery (19-20). The superior rectal artery is the direct continuation of the inferior mesenteric artery and supplies the lower part of the rectum, the upper part of the anal canal and the internal sphincter. The middle rectal artery is a branch of the internal iliac artery and supplies the middle part of the anal canal, it has an anastomosis with the terminal branches of the superior rectal artery. The inferior rectal artery is a branch of the pudendal artery (derived from the internal iliac artery) and supplies both sphincters as well as the lower part of the anal canal. 
Table I, the morphology of the external anal sphincter

\begin{tabular}{|c|c|c|c|}
\hline $\begin{array}{l}\text { studies of: } \\
\text { no of specimens: }\end{array}$ & $\begin{array}{l}\text { Schrøder (23) } \\
6\end{array}$ & $\begin{array}{l}\text { Beersiek (24) } \\
16 * *\end{array}$ & $\begin{array}{l}\text { this thesis }(25) \\
6 * * *\end{array}$ \\
\hline type I fibers $(\%)$ & $86[80,92]$ & $78[72,83]$ & $80[69,91]$ \\
\hline diameter type I fibers $(\mu \mathrm{m})$ & $21[8,35]$ & $22[17,29]$ & $29[25,33]$ \\
\hline collagen $(\%)$ & - & - & $12[10,14]$ \\
\hline
\end{tabular}

* frozen in isopenthane analyzed with TGZ3 (Zeiss, Jena, FRG), ** frozen in isopenthane/liquid nitrogen analyzed with eye piece meter, *** formalin fixed, paraffin embedded analyzed with computer assisted morphometry. The data are expressed as mean and $95 \%$ confidence intervals.

\section{Morphology of the anal sphincters}

The findings by Floyd and Walls and Porter that the external anal sphincter is in a state of tonic contraction (21-22) and that this muscle is capable to increase its activity during a voluntary contraction are reflected by specific histological features (table I).

These 3 morphological studies of Schrøder et al., Beersiek et al, and our own work are in agreement with each other and the small differences may be attributed to the different analytical methods.

A predominance of type I fibers with a small diameter and (in our studies) a high amount $(12 \%)$ of collagen should be considered as the normal histological pattern of the sphincter (23-25). Type I fiber predominance is known to be a characteristic feature of muscles with a tonic, postural function (26). As a consequence, the external anal sphincter is capable of a sustained contraction.

\subsection{TOPOLOGY AND MORPHOLOGICAL CHARACTERISTICS OF MUSCLES SUITED FOR SPHINCTEROPLASTY}

A severely damaged and/or denervated or an absent sphincter (e.g. patients with anal atresia or patients with a stoma) should be replaced. This can be performed, using skeletal muscle transposition with intact neurovascular supply. Sphincters around a stoma have been created, using rectus muscle in animals (27). Cavina et al. explored the use of sartorius muscle transposition in cadavers (28). Partial (one sided/or bilateral) gluteus transposition and gracilis transposition have been used for the treatment of anal incontinence (29-33). In the following sections the topology and morphology of these muscles will be described: 


\section{Rectus abdominis}

The rectus abdominis muscle is a long muscular band, it arises with two heads from the symphysis pubis and pubic crest and is attached (with some variation) to the fifth, sixth and seventh costal cartilages and the xiphoid process. The cranial part is three times as wide as the caudal part. The left and right rectus muscle are separated by the linea alba. The anterior surface of the muscle is crossed by two or three tendinous intersections which are closely attached to the anterior side of the rectus sheath. The rectus is supplied by the thoracoabdominal and subcostal nerves. The arterial supply is, from the inferior and superior epigastric arteries and the intercostal arteries (34-37). The rectus abdominis muscle protects the viscera, tenses the abdominal wall and stabilizes the pelvis. The rectus may increase intra-abdominal pressure and assist during forced expiration, acting together with the three other abdominal flat muscles. But, it may have barely a function in the maintenance of posture. The rectus has a role in the "head rising movement" but not in ordinary standing (38). The rectus has a mean of $46 \%$ type I fibers with a mean diameter of $43 \mu \mathrm{m}$ (table II)

\section{Sartorius}

The sartorius muscle arises from the anterior superior iliac spine and runs downwards and is attached to the upper part of the medial shaft of the tibia. It is a narrow strap like muscle. The sartorius is the most anterior of the "pes anserinus" muscles (39-41). The muscle is supplied by the femoral nerve ((L2), L3, L4). The vascularization is from segmental pedicles of the superficial femoral artery (42). Occasionally, the muscle is bicipital at its proximal end, sometimes it is absent $(43,44)$. The sartorius is active during flexion of the thigh, irrespective of flexion of the knee. The greatest activity of the sartorius (EMG recordings) is found when the hip is flexed with the knee maximally bend. The sartorius is only minimally active during walking (45). The sartorius has a mean of $50 \%$ type I fibers with a mean diameter of $48 \mu \mathrm{m}$ (table II).

\section{Gluteus maximus}

The gluteus maximus arises from the outer surface of the os ileum behind the posterior gluteal line, the sacrum, coccyx and the sacrotuberous ligament. The muscle inserts to the ileotibeal tract and the gluteal tuberosity of the femur and is the most superficial muscle of the buttocks. The muscle is innervated from the inferior gluteal nerve (L5, S1, S2). The vascularization is from both the superior and inferior gluteal artery $(39,46,47)$. It is a muscle with two dominant arterial pedicles like the rectus muscle (42). Variations occur and a fusion between gluteus maximus and tensor fascia lata has been described (48-50). The gluteus maximus functions as an extensor and lateral rotator of the hip and is used as an 
Table II, the morphology of muscles suited for sphincteroplasty

\begin{tabular}{lllll}
\hline & rectus abdominis & sartorius & gluteus & gracilis \\
\hline & Johnson & & & this thesis \\
\hline no. of specimens & $36^{*}$ & $36 *$ & $36^{*}$ & $11 * *$ \\
type I fibers $(\%)$ & $46[35,57]$ & $50[40,60]$ & $52[36,67]$ & $43[39,46]$ \\
diameter $(\mu \mathrm{m})$ & $43[32,55]$ & $48[39,57]$ & $56[31,84]$ & $43[38,48]$ \\
collagen $(\%)$ & - & - & - & $4[3,5]$ \\
\hline
\end{tabular}

* data from Johnson et al. The biopsies were frozen in isopenthane and analyzed with TGZ3 (Zeiss), ** the biopsies were formalin fixed and paraffin embedded and analyzed with computer assisted morphometry. Data are expressed as mean and $95 \%$ confidence intervals.

extensor of the trunk. It is not an important postural muscle (51-53). But, normal walking is disturbed when the muscle is completely paralysed. The gluteus has a mean of $52 \%$ type I fibers with a mean diameter of $56 \mu \mathrm{m}$ (table II).

\section{Gracilis}

The gracilis arises from the outer surface of the inferior ramus of the pubis and ischium. It is the most superficial muscle on the medial side of the thigh. The muscle is broad above and it tapers while running downwards. The gracilis is attached to the upper part of the medial shaft of the tibia. Its distal tendon is in our experience flat. The tendon is the middle tendon of the pes anserinus (54). The muscle is supplied by the anterior division of the obturator nerve (L2, L3 (L4)) which enters the muscle from the postero-lateral side as a main trunk and three branches $(55,56)$. The mair vascular pedicle arises from the profunda femoris $(32,57)$. Minor pedicles may derive from the superficial femoral artery and the obturator artery. Occasionally, the dominant pedicle is a branch of the medial femoral circumflex artery (42). Radiocontrast injection studies have shown intramuscular arterio-arterial anastomoses between the main and minor pedicles (57). Anomalies are infrequent although a gracilis biceps has been described (58). The gracilis adduces the thigh (as the other adductors) and is active in hip flexion if the knee is extended but not if the knee is flexed simultaneously (59). The gracilis as well as sartorius muscle have no clear function in humans $(41,53)$ but these muscles may compensate for the impaired function of other upper leg muscles in affected individuals. The gracilis has $43 \%$ type I fibers with a mean diameter of $43 \mu \mathrm{m}$.

\section{Morphology of muscles suited for sphincteroplasty}

The four described muscles (rectus, sartorius, gluteus and gracilis) are all phasically active. This is reflected by their histological features (table II). 
Previous work of Johnson et al. and our study (table II) demonstrate that these four muscles have 40 to $50 \%$ type I fibers with a relatively large diameter $(26,60)$. The gracilis muscle had in our study a low $(4 \%)$ collagen content $(25)$.

\subsection{DISCUSSION}

None of the described muscles is essential for locomotion and/or posture. Therefore, each of these muscles may be transposed to construct a new sphincter for continence. The pattern of vascularization and innervation determines the feasibility and safety of such a transposition in colorectal surgery. The rectus has been used in animal experiments and the use of sartorius has been explored in cadavers to create a sphincter around a stoma $(27,28)$. The gluteus and the gracilis have been used to create a new anal sphincter in patients (29-32).

The feasibility of transposed rectus abdominis to serve as a sphincter around a stoma seems good and its applications and limitations are described in chapter 3. The sartorius seems less well suited, due to its segmental vascularization which restricts its arch of rotation if the muscle is transposed to construct a new sphincter. However, the sartorius is very well suited to create a neosphincter around a stoma in dog experiments $(61,62)$ and this application is described in chapter 4.

Partial (one-sided or bilateral) gluteus has been used in patients and its feasibility as a new anal sphincter is excellent as this muscle owns two dominant arteries, making it suitable for partial transposition. So, the vascularization of the inferior part of this muscle will remain good after transposition. On the other hand, muscle splitting is necessary to surround the anal canal. The Hentz technique (31) uses both gluteus muscles to surround the anal canal whereas for example the Devesa and Starke techniques use one gluteus muscle only (29-30). Partial gluteus muscle transposition (for restoration of the anal sphincter) does not affect hip and thigh mobility (29).

The most common transposition procedure to replace an insufficient anal sphincter, is the graciloplasty (32-33). The gracilis is a long thin muscle and a circular loop can be constructed around the anal canal with undisturbed innervation and vascularization. However, the distal part of gracilis is supplied by segmental arteries. Therefore, the vascularization of this distal part of the gracilis muscle is vulnerable. Dissection of this muscle part may be troublesome (42). 
Although gracilis and gluteus are anatomically suited to construct a muscular neosphincter in patients, functionally these two muscles do not resemble the external anal sphincter (table I and II) and their action depends upon voluntary contraction. This discrepancy between morphological and topological characteristics make these muscles less well suited for sphincter function. However, electrical stimulation is known to induce transformation of the intrinsic characteristics of skeletal muscles. The use of transposed and electrically stimulated skeletal muscles may therefore offer new prospects for faecal continence (63). 


\section{References}

1 Langenmeijer RAThM, Molenaar J. Defaecation problems in children: anatomy, physiology and pathophysiology of the defaecation mechanism. Neth J Surg 1991: 43: 208-12

2 Jacobs PPM, Kuypers JHC, Dony JMJ, Vingerhoets MH. Incontinentie voor faeces en obstetrisch letsel; betekenis van beschadigde bekkenbodeminnervatie en resultaten van chirurgische behandeling. Ned Tijdschr v Geneesk 1989; 133: 1648-51

3 Bennet RC. Duthie HL. The functional imponance of the intermal anal sphincter. $\mathrm{Br} J$ Surg 1964; 51 : $355-7$

4 Speakmann CTM, Kamm MA. The internal anal sphincter-new insights into faecal continence. Gut 1991; 32: 345-6

5 Frenckner B. Euler $v$ Chr. Influence of pudendal block on the function of the anal sphincters. Gut 1975; 16: 482-9

6 Frenckner B, Ihre T. Influence of autonomic nerves on the internal anal sphincter in man. Gut 1976; 17: 306-12

7 Tichy $M$. The development and organization of the sphincter ani extemus and the adjacent part of the levator ani muscle in man. Folia Morphologica 1984; 32: 113-20

8 Thomson JPS, Akwari OE. Disorders of the anal canal. In: Sabiston DC (ed). Texibook of Surgery (14 ${ }^{e}$ edition). Philadelphia: Saunders 1991; $958-72$

9 Lawson JON. Pelvic anatomy (II). Anal canal and associated sphincters. Ann Roy Coll Surg 1974; 54: 288-300

10 Aronson MP, Lee RA, Berquist TH. Anatomy of anal sphincters and related structures in continent woman studied with magnetic resonance imaging. Obstetrics and Gynecology 1990; 76: 846-51

11 Parks AG. Modem concepts of the anatomy of the anorectal region. Post grad Med 1958; 34: 360

12 Bergman RA, Thompson SA, Afifi AK, Saadeh FA. Pelvic diaphragm and anus. In: Compendium of Human Anatomic Variation. Baltimore: Urban and Schwarzenberg. 1988; $21-2$

13 Milligan ETC, Morgan CN. Surgical anatomy of the anal canal, with special reference to anorectal fistula. Lancet 1934 (ii); 1150-56, 1213-7

14 Ayoub SF. The anterior fibres of the levator ani in man. J Anat 1979; 128: 571-80

15 Goligher JC, Leaccock AG, Brossy JJ. The surgical anatomy of the anal canal. Br J Surg 1955; 43: 51-61

16 Ayoub SF. Anatomy of the external anal sphincter in man. Acta Anat 1979; 105: 25-36

17 Oh C, Kark AE. Anatomy of the external anal sphincter. Br J Surg 1972; 59: 717-23

18 Shafik A. A new concept of the anatomy of the anal sphincter mechanism and the physiology of defecation. I. The external anal sphincter: A triple-loop system. Invest Urol 1975; 12: 412-19

19 Ayoub SF. Arterial supply to the human rectum. Acta Anatomica 1978; 100: 317-27

20 Michels NA, Siddharth P, Komblith PL, Park WW. The variant blood supply to the descending colon, rectosigmoid and rectum based on $\mathbf{4 0 0}$ dissections. Its importance in regional dissections: a review of medical literature. Dis Colon Rectum 1965; 8: 251-78

21 Floyd WF, Walls EW. Electromyography of the sphincter ani externus in man. J Physiol 1953; 122: 599-609 
22 Porter NH. A physiological study of the pelvic floor in rectal prolapse. Ann Roy Coll Surg 1962; 31: 379-404

23 Beersiek F, Parks AG, Swash M. Pathogenesis of ano-rectal incontinence. J Neurol Sci 1979; 42: 111-27

24 Schrøder HD, Reske-Nielsen E. Fiber types in the striated urethral and anal sphincters. Acta Neuropathol (Berl) $1983 ; 60 ; 278-82$

25 Konsten J, Baeten CGMI, Havenith MG, Soeters PB. Morphology of dynamic graciloplasty compared with the anal sphincter. Dis Colon Rectum 1992; 35: P45

26 Johnson MA, Polgar J, Weightman D, Appleton D. Data on the distribution of fibre types in thirty-six human muscles. An autopsy study. J Neurol Sci 1973; 18: 111-29

27 Rosenberg PH, Geiss AC, Nelson RL, Tortolani AJ. Model of intestinal continence using an implantable pulse generator and a myoprosthetic sphincter. TASAIO 1989; 35 : 222-5

28 Cavina E, Seccia M, Evangelista G. Neo-sphincter and neo-stomy New surgical views for myoelectric stimulated continence. A clinical experience. Preliminary report. American Journal of Proctology Gastroenterology and Colon and Rectal Surgery 1982; 33: 16-9

29 Devesa JM, Vincente E, Eniquez JM, Nuno J, Bucheli P, Blas G, Villanueva MG. Total fecal incontinence-A new method of gluteus maximus transposition; preliminary results and report of previous experience with similar procdures. Dis Colon Rectum 1992; 35: 339-49

30 Starke J, Braun J, Gruwez J, Schumpelick V. Transposition des musculus glutaeus maximus zum sphincterersatz bei analer inkontinenz. Chrirurg 1992; 63: 56-61

31 Hentz VR. Construction of a rectal sphincter using the orgin of gluteus maximus muscle. Plast Reconstr Surg 1982; 70: 82-5

32 Pickrell KL, Broadbent TR, Masters FW, Metzger JT. Construction of a rectal sphincter and restoration of anal incontinence by transplanting the gracilis muscle: a report of four cases in children. Ann Surg 1952; 135: 853-63

33 Cormann ML. Management for fecal incontinence by gracilis muscle transposition. Dis Colon rectum 1979; 22: 290-2

34 Moore $\mathrm{KL}$. The abdomen In: Clinically orientated anatomy ( 2 edition). Baltimore: Williams and Wilkins, 1984; 168-9

35 Williams R, Warwick R, Dysen M, Bannister LH. Neurology of the thoracic ventral rami. In: Williams PL (ed) Gray's anatomy $\left(37^{\circ}\right.$ edition). Edinburgh: Longmans 1989; $1173-40$

36 Boyd JB, Taylar GI, Corlett R. The vascular territories of the superior epigastric arteries, and the deep inferior epigastric systems. Plastic Reconst Surg 1984: 73: 1-16

37 Williams PL, Warwick R, Dyson M, Bannister L.H. Fasciae and muscles of the trunk. In: Gray's anatomy (37 edition). Edinburgh: Churchill Livingstone 1989; 587-608

38 Floyd WF, Silver PHS. Electromyography study of pattems of activity of the anterior abdominal wall muscles in man. J Anat $1950 ; 84: 132-45$

39 Williams PL, Warwick R. Dyson. M. Bannister LH. Fasciae and muscles of the upper limb. In: Gray's anatomy ( $37^{\mathrm{c}}$ edition). Edinburgh: Churchili Livingstone 1989;635-60

40 Snell RS. The lower limb. In: Clinical Anatomy ( $2^{e}$ edition). Boston: Little Brown 1981: 497

41 Last RJ. The lower limb. In: Anatomy regionai and applied ( $6^{\circ}$ edition). Edinburgh: Churchill Livingstone 1978; 126-90 
42 Mathes SJ, Nahai F. Classification of the vascular anatomy of muscles: experimental and clinical correlation. Plastic and Reconstructive Surgery 1981; 67: 177-87

43 Brock GS. A two-headed sartorius. J Anat Physiol 1879; 13: 578

44 Macalister A. Observations on muscular anomalies in the human anatomy. (Third series with a catalogue of the principal muscular variations hitherto published). Trans $\mathrm{R}$ Iris Acad Sci $1875 ; 25: 1-130$

45 Johnson CE, Basmajian JV, Dasher W. Electromyography of sartorius muscle. Anat Rec 1972; 173: 127-30

46 Sinclair DC. Muscles and fascia. In: Romanes GJ (ed). Cunningham's Textbook of Anatomy $\left(12^{\mathrm{e}}\right.$ edition) Oxford: University Press 1981; 265-407

47 Snell RS. The lower limb. In: Clinical Anatomy ( $2^{\mathrm{C}}$ edition). Boston: Little Brown $1981 ; 473-597$

48 Bergman RA, Thompson SA, Afifi AK, Saadeh FA. Muscles of lower extremity. In: Compendium of Human Anatomic Variation. Baltimore: Urban and Schwarzenberg $1988 ; 22-4$

49 Levadoux M, Levêque. Note sur les insertions inferieures du muscle grand fessier. L'Assoc Anatomistes, Comptes Rendus 1907; 9: 128-9

50 Gruber W. Ein seltener Curvator coccygis accessorius beim Menschen, homolog den constanten depressor caudea longus bei gewissen Săugetieren. Arch Path Anat Physiol Klin Med 1887; 109: 1-4

51 Joseph J and Williams PL. Electromyography of certain hip muscles. J Anat 1957; 91: 186-94

52 Inman VT. Functional aspects of the abductor muscle of the hip. J Bone and Joint Surgery 1947; 29: 607-19

53 Basmajian JV. Lower Limb. In: Muscles alive $\left(4^{\mathrm{e}}\right.$ edition). Baltimore: Williams and Wilkins 1978; 235-80

54 Moore KL. The lower limb. In: Clinically orientated anatomy $\left(2^{\mathrm{e}}\right.$ edition). Baltimore: Williams and Wilkins 1984: 396-560

55 Patel J, Shanahan D, Williams NS, Sinnatamby CS, George B. Watkins ES. The anatomy of the anterior division of the obturator nerve in relation to the electrically stimulated gracilis neoanal sphincter. Clinical Anatomy 1991; 4: 385 (abstract)

56 Hollinshead WH, Markee JE. The multiple innervation of limb muscle in man. J Bone and Joint Surg 1946; 28: 721

57 Patel J, Shanahan D, Riches DJ, Sinnatamby CS, Williams NS, Watkins ES. The arterial anatomy and surgical relevance of the human gracilis muscle. J Anat 1991; 176: 270-2 (abstract)

58 Gruber W. Ein musculus gracilis biceps. Arch Path Anat Physiol Klin Med 1887; 109: 4

59 Wheatley MD, Jahnke WD. Electromyographic study of the superficial thigh and hip muscles in normal individuals. Arch Phys Med 1951; 32: 508-15

60 Polgar J, Johnson MA, Weightman D, Appleton D. Data on fibre size in thirty-six human muscles. An autopsy study. J Neurol Sci 1973; 19: 307-18

61 Evans HE, Christensen GC. Muscles. In: Miller's anatomy of the dog. Philadelphia: WB Saunders company 1979: 387-91

62 Hallan RI, Williams NS, Hutton MRE, Scott M, Pilot MA, Swash M, Koeze TH, Watkins ES. Electrically stimulated sartorius neosphincter: canine model of activation and skeletal muscle transformation. Br J Surg 1990; 77: 208-13

63 Pette D, Vrobvá G. Adaptation of mammalian skeletal muscle fibers to chronic electrical stimulation. Rev Biochem Pharmacol 1992; 120: 115-202 


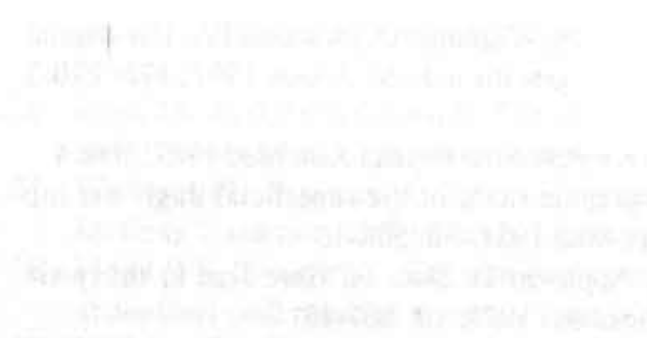

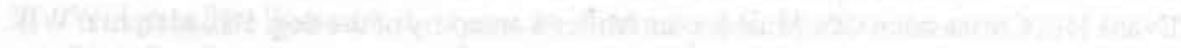

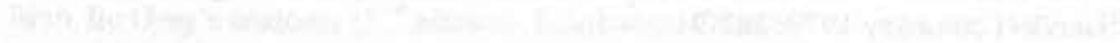

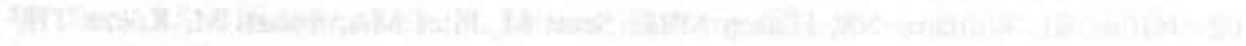

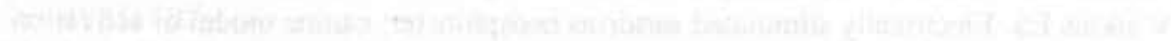

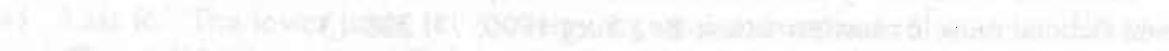

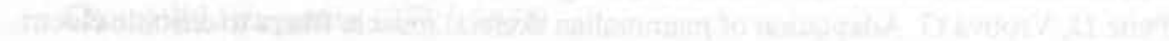

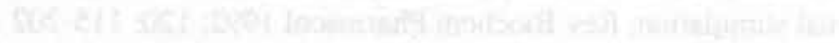




\section{Chapter 3}

The feasibility of transposed and stimulated rectus muscle to serve as a sphincter in pigs 


\subsection{INTRODUCTION}

There are 2 types of faecal incontinence; (i) anal incontinence and (ii) incontinence through a colostomy or ileostomy. Stoma incontinence can be managed with receptacles but the loss of a bodily function (faecal continence) remains a problem. Anal incontinence can be managed with sanitary pads, but is almost unbearable for the patient in a Western civilization (chapter 1).

\section{Anal incontinence}

A destroyed or congenitally absent anal sphincter should be replaced to restore faecal continence. In the past, a silver or steel wire has been used to encircle the anal canal (Thiersch wire) which creates an adynamic outlet obstruction. High infection rates decreased the enthusiasm for this procedure (1). More recently, Christiansen et al. and Wong et al. have described an artificial sphincter for anal incontinence which was modified from the AMS (American Medical Systems [AMS], Minneapolis, MN) urinary sphincter $(2,3)$. In this procedure, a silicone cuff surrounds the anal canal. The occlusive cuff is connected with a pressure regulating balloon and a control pump. If inflated, the anal canal is closed. On the other hand, defaecation is possible if the cuff is deflated. The preliminary results of the AMS sphincter have been encouraging but the feasibility of this approach needs to be confirmed during long term follow-up as infection and bowel wall erosion may interfere with the achieved results (4).

\section{Stoma incontinence}

In the past, it has been tried to achieve stoma continence with a reservoir and a nipple valve (Kock's pouch) $(5,6)$. But, even in the most experienced hands 21 to 40 percent had to be re-operated and incontinence persisted in 3 to 40 percent $(7-10)$. The nipple valve in Kock's procedure has been replaced with a porcine aortic valve but this technique never became popular (11).

Schmidt and Bruch used a smooth muscle autograft and constructed a muscular cuff to achieve stoma continence $(12,13)$. However, the graft is deprived from circulation and tends to scar. Continence in the Schmidt procedure might be obtained from obstruction and the graft might function as an autologous Thiersch only. More recently autotransplantation of the pylorus was described for stoma continence but continence was not achieved (14). The use of transposed smooth muscle for stoma continence seems rational because these fibers are capable to sustain a prolonged contraction. However, transposed smooth muscle alone does not achieve continence and acts as a mechanical obstruction only (14). 
Other procedures have used artificial material for stoma sphincters (15). Examples of these procedures are the Erlangen magnetic device, cuffs and balloon occluders (16-20). But the long-term results of artificial sphincters may be disappointing because of higher infection rates (4). A disposable colostomy plug may contribute to a better quality of life of a colostomy patient $(21,22)$ however the results with the colostomy plug are hard to verify because in a reported series of 100 patients only 29 use the plug daily (23).

Hoepfner et al. tried to achieve stoma continence in dogs with retrograde electric pacing of an isoperistaltic segment in the gut and found that it was possible to slow transit and increase absorption but continence was not achieved (24).

\section{The use of skeletal muscle for the restoration of anal and stoma continence} Rosenberg et al. used a lumen occluding Teflon ${ }^{\star}$ loop sutured to rectus abdominis muscle, which occluded the stoma at rest. Rectus muscle was activated by an implanted pulse generator and stimulation caused contraction of rectus muscle. As a result the occlusive loop loosens, resulting in free drainage of intestinal contents (25). The feasibility was proven in dogs, however the model used a completely denervated rectus muscle and artificial material, thereby limiting the clinical application.

Cavina et al. have used transposed striated oblique abdominal wall muscles to create a an electrostimulated sphincteroplasty around a stoma and trained these muscles to prolong contractions nevertheless a continuously functioning sphincter could not be obtained (26). Gluteus and gracilis muscle have been used for neosphincter construction (27-28). However, being skeletal muscles they need to be contracted voluntarily during a prolonged period of time, which is difficult to accomplish for a patient. Electrical stimulation of skeletal muscles causes contractions independent of will overcomes this problem of voluntary contractions. In addition, stimulation induces a transformation in the muscle fiber composition of skeletal muscle, allowing for the needed prolonged tonic contraction (29-30).

From an experimental point of view, an isolated segment of small bowel (Thiry-Vella-loop) with two stomata offers the opportunity to assess the feasibility of muscle transposition and an electrostimulated neosphincter $(31,32)$. Such experiments do not only test the feasibility of transposed and electrically stimulated muscle to serve as a neosphincter in animals but the results of such studies might also be used to achieve stoma continence in patients. 
The aim of this study was to explore which human abdominal muscles might be suitable as a stoma sphincteroplasty in cadaver dissections. Subsequently, the feasibility was assessed in pigs using electrically stimulated rectus muscles because the pig's rectus shape, innervation and vascularization resembles the human one.

\subsection{HUMAN CADAVER DISSECTIONS}

\section{Methods of human cadaver dissections}

Three embalmed normal cadavers ( 86,86 and 73 years old) were dissected to select the optimal abdominal muscle for sphincteroplasty around a stoma. Anatomy of the abdominal wall muscles was explored with respect to nerve supply and vascularization. The cadavers were macroscopically studied as follows; (i) the overlying skin and fascia of Camper and Scarpa were removed to gain access to the abdominal muscles; the anterior sheath of the rectus muscle was detached sharply from the ventral side of this muscle; (ii) nerve branches were dissected carefully and followed through the muscular tissue from ventral to dorsal until they reached the intercostal nerve at the dorsal muscle side; (iii) these intercostal nerves were traced until they reached the intercostal spaces. Additionally, the intramuscular parts of the nerve branches in the rectus muscle were studied, using an operation microscope (OPMI-6-F, Zeiss, Jena, FGR).

\section{Results of human cadaver dissections}

The branches of the intercostal nerves were found piercing the rectus muscle. These perforating branches could be explored from the ventral to the dorsal muscle side between rectus fibers until the site of entry of the main nerve branch was found (fig 1). From this entry point, the nerve was inside the rectus muscle sheath for about $2 \mathrm{~cm}$.

Dissection of motor branches into muscular tissue (using an operation microscope) revealed no inter-connections between nerve branches beyond the point of entrance into the muscle sheath. The oblique abdominal wall muscles were innervated from short direct branches of the intercostal nerves from points outside the rectus sheath.

The blood supply of the rectus muscle was provided by the epigastric and intercostal arteries. The superior epigastric artery entered the muscular tissue above the costal margin. The inferior epigastric artery runs dorsally to the muscle, penetrates its sheath and branches-off small arteries. The main branch of the inferior epigastric artery entered the muscle at the level of the umbilicus. Anastomoses connecting the terminal branches of intercostal and subcostal 


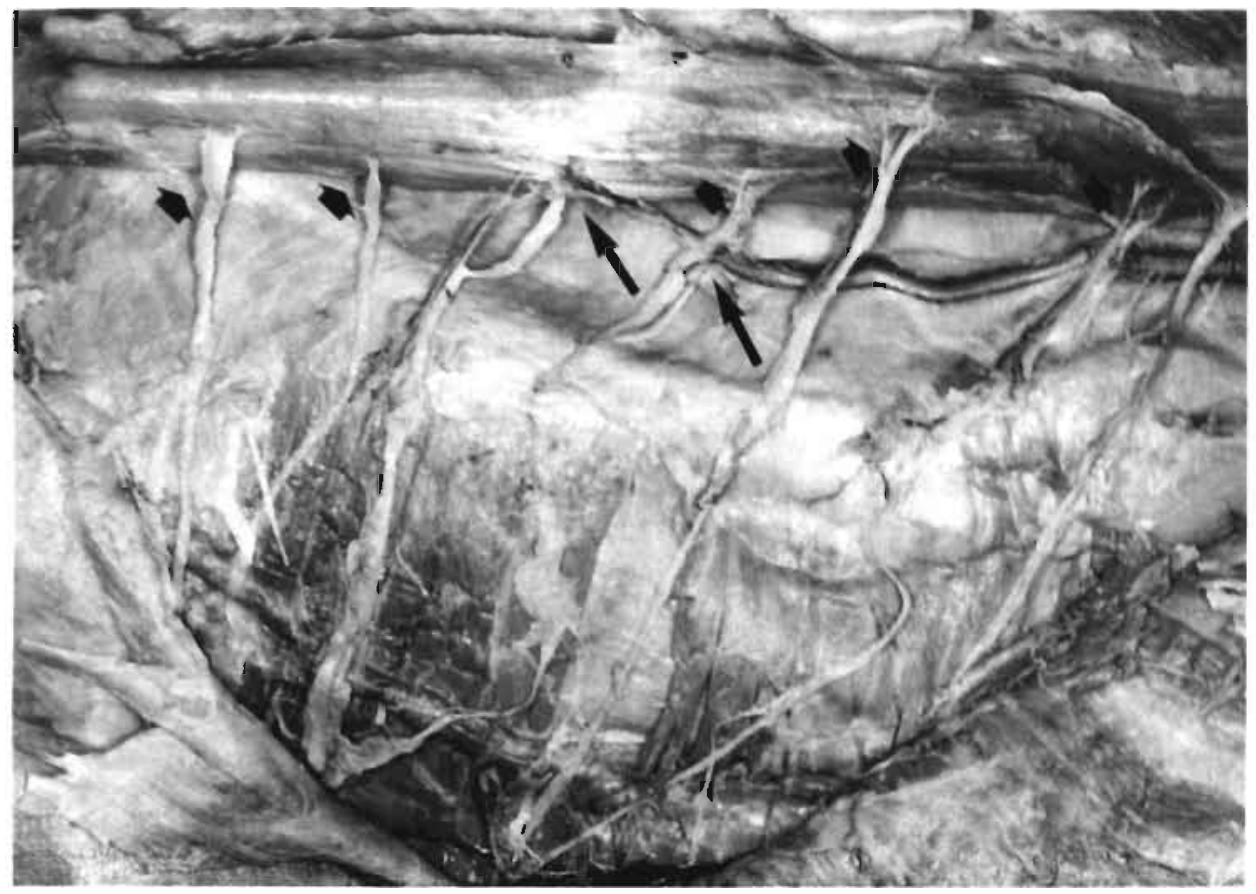

Figure 1. Human cadaver dissection of the right rectus abdominis muscle is shown. The right side of the picture is situated caudally. The rectus has been tumed over and the dorsal muscle side is demonstrated. The nerve entry point of the intercostal nerves into the rectus muscle is accentuated with small arrows. The anastomosis between the intercustal arteries and epigastric arteries is marked by a big arrow.

arteries with the epigastric arteries could be identified (figure 1). The vascularization of the oblique abdominal muscles was provided by short branches of the intercostal arteries outside the rectus sheath.

\subsection{ANIMAL EXPERIMENTATION}

\section{Surgical procedures in animals}

\section{Animals}

Six pigs were used with a mean weight of $25 \mathrm{Kg}$. The animals were fasted 24 hours before surgery. Anaesthesia was induced with azaperon $8 \mathrm{mg} / \mathrm{kg}$ (Janssen, Goirle, The Netherlands) and maintained after endotracheal intubation with a nitrous oxide, oxygen $(1: 2)$, halothane mixture $(0,8 \%)$ (ICI, Rotterdam, The Netherlands). Antibiotic prophylaxis consisted of ampicillin $(25 \mathrm{mg} / \mathrm{kg}$ iv.) (Kombivet, Etten Leur, The Netherlands). Surgery was performed under strictly 
aseptic conditions. The animals were treated according to Dutch legislation and the studies were approved by the animal ethical committee of the University of Limburg.

\section{Surgical techniques}

Access to the abdominal cavity was obtained via a median laparotomy. A $20 \mathrm{~cm}$ segment of jejunum was isolated as a Thiry-Vella loop (fig 2A). Continuity of the gut was restored with a monolayer hand-sewn anastomosis and the new sphincter (sphincteroplasty) was constructed around the Thiry-Vella loop. Three different surgical techniques were used. Firstly, a muscular ring was constructed, using the right proximal rectus muscle (fig $2 \mathrm{~B}$ and $2 \mathrm{C}$ ) in 2 pigs. A similar procedure was used at the left side in 1 of these 2 pigs.

A second method employed was to pull the distal end of the Thiry Vella loop (fig 3 ) through the middle of each rectus muscle in 1 pig.

Lastly, a sling was constructed using the distal part of the rectus muscle in 3 pigs (fig 4). In these 3 pigs an exactly analogous procedure was performed on the left side.

\section{Implantation of the stimulation equipment}

All rectus muscles were electrically stimulated, using SP 5548 intramuscular electrodes (Medtronic, Kerkrade, The Netherlands) and an implanted Itrel ${ }^{\mathrm{TM}}$ pulse generator. The cathode was placed in the lateral muscle side at the nerve entry side while the anode was placed inside the medial side. Stimulation of the right rectus muscles $(n=6)$ was started 1 week after the operation as follows: frequency $25 \mathrm{~Hz}$, pulse width 210 microseconds, time "on" 0.125 seconds and time "off" 2 seconds during 2 weeks, starting with a mean stimulation voltage of $3.7 \mathrm{~V}$. The following 2 weeks time off was reduced to 1 second ( 6 pigs). The left rectus muscle in 4 of these 6 pigs was stimulated unremittingly with $2 \mathrm{~Hz}$ and a pulse width of 210 microseconds, starting with an mean stimulation voltage of $3.6 \mathrm{~V}$.

\section{Evaluation: muscle morphology}

Open muscle biopsies were taken during and 5 weeks after surgery to investigate muscle fiber types. The percentage of type I (relatively fatigue resistant muscle fibers) was assessed using the monoclonal antibody R11D10 directed against the myosin heavy chain of type I, presumably fatigue resistant muscle fibers (33). Muscle wrapping with the proximal rectus muscle and splitting the rectus muscle (figures 2 and 3 ) might cause partial denervation of this muscle. Therefore, several biopsies were taken to detect denervation and subsequent muscle atrophy. A substantial increase in connective tissue and increased variability of muscle fiber diameter were considered as the morphologic substrate of atrophy. 

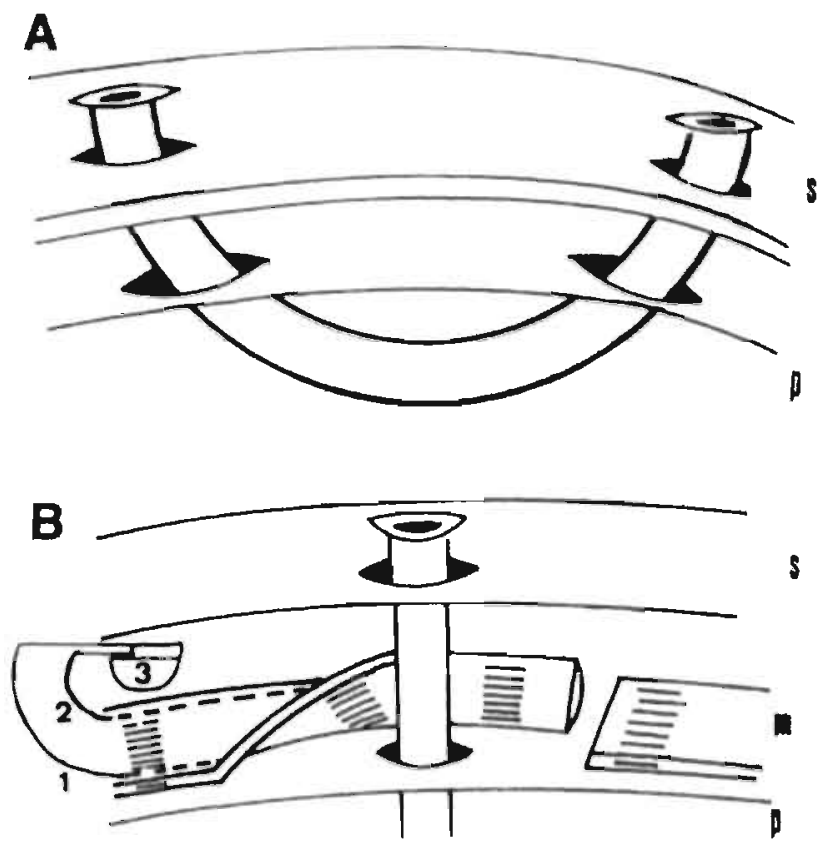

Figure 2, sphincteroplasty with proximal rectus muscle In figure $2 \mathrm{~A}$ the construction of the Thiry Vella loop is

C

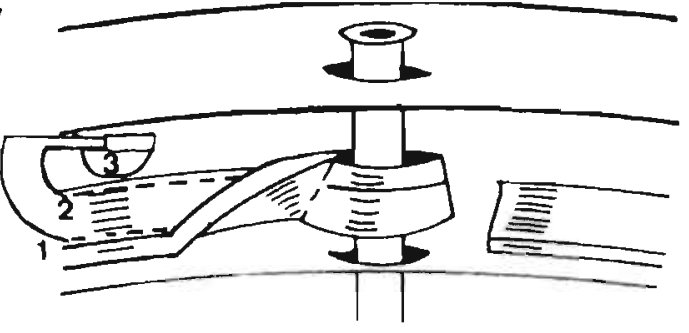
shown, figure 2B shows the proximal end of the Thiry

$\delta$ Vella loop and rectus muscle is mobilized. In figure $2 \mathrm{C}$ the muscle is positioned around the Thiry Vella loop and sutured to itself as a sphincter. "S" = skin, "P" = peritoneum, "M" = muscle. " $l "=$ anode, "2" = cathode and " 3 " = implanted pulse generator.

Figure 3. The distal end of the Thiry Vella loop is pulled through the rectus muscle, which however destroyed some intramuscular nerve branches. " $\mathrm{S}$ " = skin, "P" = peritoneum, "M" = muscle, " 1 " = anode, " 2 " = cathode and " 3 " = implanted pulse generator 

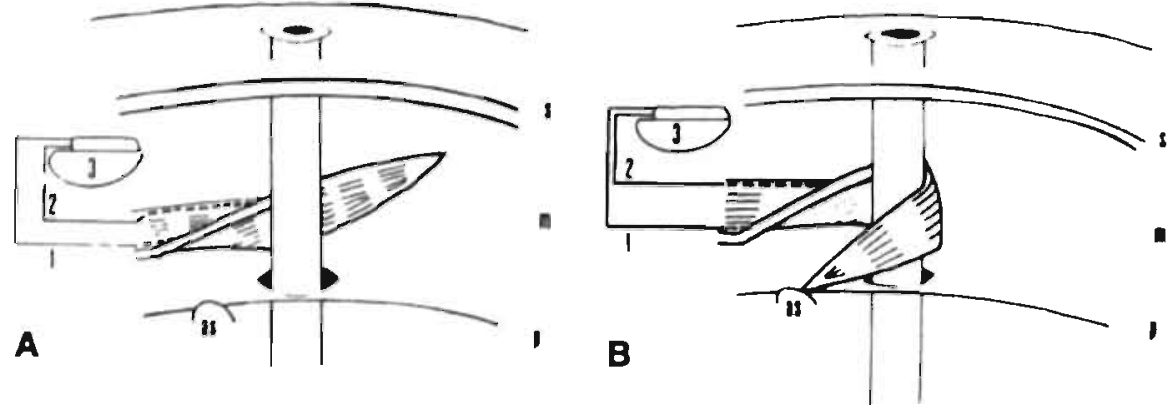

Flgure 4. The distal end of the rectus muscle is mobilized from its insertion to the pubic bone leaving innervation and vascularization intact (fig 4A). Subsequently, the mobilized muscle is positioned around the Thiry Vella loop (fig 4B). Then, the rectus tendon is sutured to the ipsilateral superior anterior iliac spine (AS). "S" = skin, "P"= peritoneum, "M"= muscle, " 1 " = anode, "2" = cathode and " 3 " = implanted pulse generator

\section{Evaluation: manometry and stoma continence}

The new sphincters function was evaluated at 1 and 5 weeks after surgery, using $25 \mathrm{~Hz}$ continuous electrical stimulation of the sphincters, inducing fused contractions. Stimulation voltage was increased until registration was possible. Manometry of the new sphincters was performed with a microtransducer (Millar Instruments, Houston, Texas, USA), which was connected to a recorder writer. Stoma continence was assessed as follows; 1) a urinary catheter was introduced into the Thiry Vella loop which was connected with a saline cylinder from a height of $60 \mathrm{~cm}$ with stimulation "off"; 2) stimulation of the sphincteroplasty was turned "on" with the previously determined stimulation voltage; and 3) the capability of the new sphincter to inhibit flow was assessed during 3 minutes by visual control.

Data were expressed as mean and $95 \%$ confidence intervals. Statistical analysis was done using the computer program SPSS/PC+ (Microsoft, Chicago, Illinois, USA). Differences were considered significant if $\mathrm{P}<0.05$ using student's t-test for paired data or the Mann-Whitney test to compare groups.

\section{Results in animals}

\section{Surgical procedures in animals}

Animal weight increased from a mean of 25 [C.I. 20, 30] to $36 \mathrm{Kg}$. [C.I. 33,39] after 5 weeks. Three complications occurred as 3 animals developed a small subcutaneous abscess, which did not interfere with muscular contractions. 

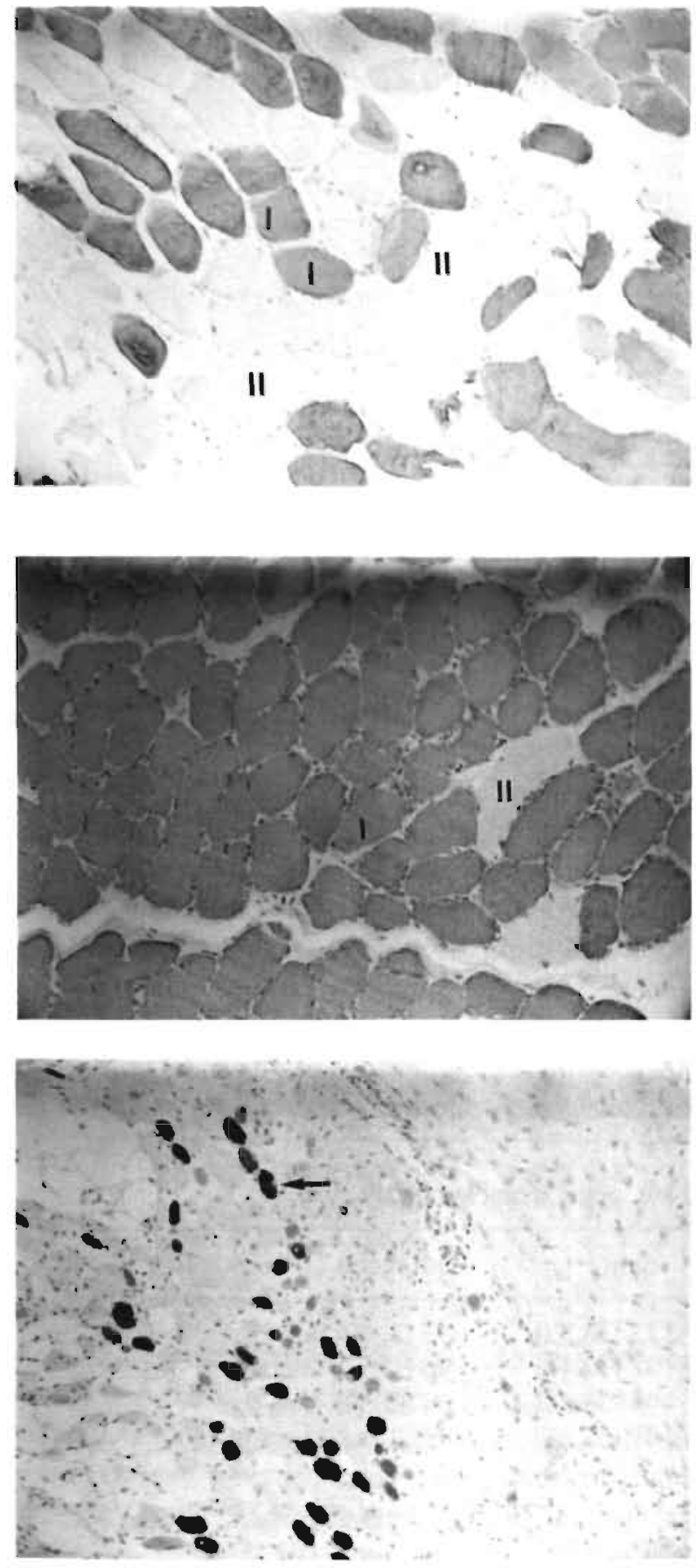

Figure 5a, morphology of proximal rectus muscle before surgery. Type 1, relatively fatigue resistant muscle fibers stain dark with the monoclonal antibody R11D10 and are marked with "I". Type II, quickly fatiguable muscle fibers are marked "II". original magnification $=\times 125$

Figure 5b, demonstrates an innervated area after transposition and stimulation. An increased percentage of type I fibers (staining dark with the monoclonal antibody RIIDI0) was found. original magnification $=\times 125$

Figure 5c, shows a denervatcd area in which an increased amount of connective tissue was found as well as variability of muscle fiber diameter. The arrow is indicating a small type I muscle fiber which stains dark with the monoclonal antibody RIID10. original magnification $=\times 125$ 
Table I, morphology percentage type I fibers

\begin{tabular}{lll}
\hline time (weeks) & right $(25 \mathrm{~Hz})$ & left rectus $(2 \mathrm{~Hz})$ \\
\hline$t=1$ & $42[36,48]$ & $50[33,67] \%$ \\
$t=5$ & $65[50,80]$ & $67[34,99] \%$
\end{tabular}

The percentage of type I muscle fibers is expressed as mean and $95 \%$ confidence intervals [CI]. $t=1$ means 1 week after surgery (no stimulation), $t=5$ means 5 weeks after surgery (4 weeks electrical stimulation).

\section{Muscle morphology}

The biopsies of innervated right as well as left rectus muscle parts revealed (table I) a significantly increased percentage of type I fibers $(\mathrm{P}<0.05)(\mathrm{fig} 5)$.

No significant differences ( $\mathrm{P}>0.05$ ) were found between 25 (right) and $2 \mathrm{~Hz}$ (left rectus muscle) stimulation (table I). Substantial atrophy and fibrosis were found macroscopically as well as microscopically in denervated rectus areas. Constructing a muscular ring (figure 2) caused atrophy as a result of denervation due to transection of intercostal nerve branches in 2 animals (fig 5C).

The same morphological findings as demonstrated in figure $5 \mathrm{C}$ were observed when the Thiry Vella loop was pulled through the rectus muscle (fig 3 ). In this technique, atrophy was due to dissection of small intramuscular nerve branches in 1 animal. Construction of a sling (fig 4) did not cause any substantial muscle atrophy (fig 6) after transposition and stimulation.

\section{Manometry and stoma continence}

The pressure in the Thiry Vella loup increased because of electrical stimulation of the right as well as left sphincteroplasty, one week after surgery (table II).

Table II, manometry of right and left rectus sphincteroplasty

\begin{tabular}{llll}
\hline time (weeks) & right & left rectus \\
\hline $\mathrm{t}=1$ & stimulation "off" & $23[13,33]$ & $31[2,60] \mathrm{mm} \mathrm{Hg}$ \\
$\mathrm{t}=5$ & stimulation "on" & $32[17,47]$ & $46[-5,97] \mathrm{mm} \mathrm{Hg}$ \\
& stimulation "off" & $48[38,58]$ & $44[26,60] \mathrm{mm} \mathrm{Hg}$ \\
& stimulation "on" & $47[37,57]$ & $48[22,64] \mathrm{mm} \mathrm{Hg}$ \\
\hline
\end{tabular}

$t=1$ week means 1 week after surgery (no electrical stimulation), $t=5$ means 5 weeks after surgery (4 weeks electrical stimulation). 

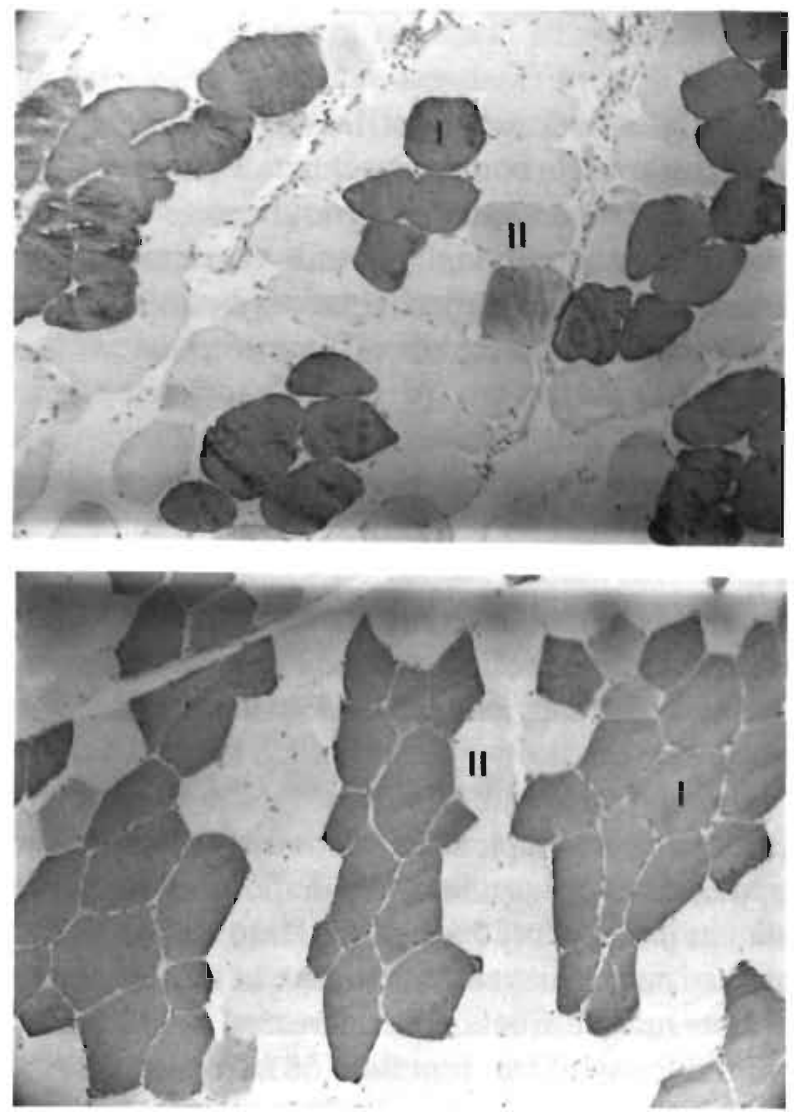

Figure 6a, morphology of disial rectus muscle before sling construction and stimulation. Sections are monitored with the: monoclonal antibody RIIDI0, directed against type I muscle fibers. Type I muscle fibers are marked with "l". original magnification $=x .125$

Figure 6b, demonstrates a section after transposition and stimulation which shows an increased percentage of type I fibers. No areas were detected with increased connective tissue content or variability in muscle fiber diameter. original magnification $=\times 125$

Table III, voltage during manometry

\begin{tabular}{lll}
\hline time (weeks) & right $(25 \mathrm{~Hz})$ & left rectus $(2 \mathrm{~Hz})$ \\
\hline$t=1$ & $3.7[2.7,4.7]$ & $3.6[2.3,4.9]$ Volts \\
$t=5$ & $6.7[4.9,8.5]$ & $7.2[5.0,9.4]$ Volts \\
\hline
\end{tabular}

The pressure rise in stimulated muscles did not reach significance. Also, differences between left and right rectus muscles were also not significant $(\mathrm{P}>0.05)$. The electrically induced increase in pressure was not maintained after 5 weeks despite of an increased stimulation voltage (table III). No significant differences were found between $25 \mathrm{~Hz}$ (right) and $2 \mathrm{~Hz}$ (left rectus muscle) of stimulation. Saline flow through the Thiry Vella loops could not be inhibited by all stimulated new sphincters. After the experiments, the stimulation equipment was found to be undamaged in all animals. 


\subsection{DISCUSSION}

Anatomical studies of the nerve and vessel supply of human abdominal wall muscles demonstrated that the rectus muscle could be technically most suitable for sphincter construction. The muscle is innervated by several nerves branching inside the rectus sheath into the muscle. Additionally, rectus vascularization is known to be dual $(34,35)$. Therefore, we expected that transection of one of these arterial contributions could be performed for sphincter construction without resulting in ischaemic damage.

Pigs have been used to explore the three surgical techniques because the innervation and vascularization of the pig rectus muscle resembles the human anatomy (34-36). In addition, pig rectus muscle biopsies demonstrated $42 \%$ [CI $37,47]$ type I muscle fibers in this series whereas human autopsy studies revealed $46 \%$ [CI 36, 57] (relatively fatigue resistant) type I muscle fibers (37). This concordance in muscle fiber types suggests a functional resemblance of human and pig rectus muscles.

Two different stimulation pattems were applied in the same animals after surgery because stimulation appeared to be harmless. We demonstrated that the two different electrical stimulation protocols $(25 \mathrm{~Hz}$ and $2 \mathrm{~Hz})$ resulted in both a contraction of the new sphincter and achieved an increase in the number of type I (relatively fatigue-resistant) muscle fibers. The increased percentage of type I fibers is considered essential for sphincter function (38). Consequently, it appears that electrically induced activity of transposed rectus muscle increases the percentage of type I fibers irrespective of the stimulation pattern in this study since the 2 applied stimulation protocols gave the same results. Functional results of rectus muscle sphincteroplasty were disappointing. The construction of a muscular ring (fig 2) gave rise to substantial denervation and subsequent muscle atrophy (fig 5C). The same was true for dissection of the muscle (fig 3), even over a short distance $(1.5 \mathrm{~cm})$. This is in agreement with the cadaver dissections which demonstrated that rectus muscle is innervated by terminal nerve branches. It is reasonable that muscle atrophy and fibrosis have a deleterious effect on functional sphincter closure. Transposition of the distal part of the rectus muscle with intact innervation and vascularization from the pubic bone to the anterior iliac spine (fig 4) did not cause muscle atrophy (fig 6). However, the function of this sphincteroplasty was disappointing, most likely because the dorsal part of the Thiry-Vella loop was not covered completely with muscle fibers. The increased sphincter pressure at one week (table II) could not be maintained after 5 weeks despite the significantly increased stimulation voltage (table III). The results imply that these techniques are not suitable for sphincteroplasty around a stoma. 
In conclusion, different electrical stimulation pattems increase the number of type I (relatively fatigue-resistant) muscle fibers which is a prerequisite for sphincter function (38). The 3 described surgical techniques are less appropriate for sphincteroplasty. Construction of a muscular ring as well as pulling the Thiry-Vella loop through the rectus muscle causes partial atrophy of the rectus abdominis muscle. Construction of a sling did not cause atrophy, but function was not optimal probably because the dorsal side of the Thiry Vella loop was not completely covered with muscle. Therefore, sphincter construction with the rectus muscle is limited by the nerve and vascular supply of this muscle. However, this study demonstrates that transposed and electrically stimulated muscle with intact innervation and vascularization is capable of prolonged contractions. This has been previously demonstrated by Hallan et al. and Heine et al. in dogs, using the sartorius muscle $(31,32)$.

Achieving stoma continence at present is therefore hampered by anatomical and surgical difficulties whereas skeletal muscle can be induced to maintain a continuous tonic contraction by electrical stimulation. The use of other surgical techniques or other electrically stimulated muscles for stoma sphincteroplasties therefore deserves to be further explored. Recently, Guelinckx reported his experience with free microneurovascular muscle grafts in rabbits. In these experiments, latissimus dorsi muscle was transplanted to the lower extremity with a free microneurovascular anastomosis. Nearly $70 \%$ of the maximum isometric tension was maintained in these transplanted microvascular muscle grafts (39). Such a procedure might be used to transplant gracilis muscle with a free microneurovascular anastomosis to create a sphincter for faecal continence with assistance of implanted intramuscular electrodes and a pulse generator. 


\section{REFERENCES}

1 Gabriel WB. Thiersch operation for anal incontinence. Proc Roy Soc Med 1948; 4I: 467-8

2 Christiansen J, Spars $\emptyset$ B. Treatment of anal incontinence by an implantable prosthetic sphincter. Ann Surg 1992; 215: 383-6

3 Wong WD, Rothenberger DA, Bartolo DC. An artificial anal sphincter. Dis Colon Rectum 1992; 35: P4

4 Savata RM, King GE. An artificial anal sphincter: phase 2: implantable sphincter with a perineal colostomy. J Surg Res 1989; 46: 207-1 1

5 Kock NG. Continent Ileostomy. Progr Surg 1973; 12; 180-201

6 Kock NG. Intra-abdominal "reservoir". In patients with permanent ileostomy: preliminary observations on a procedure resulting in fecal "continence" in five ileostomy patients. Arch Surg 1969; 99: 223-31

7 Kock NG, Myrvold HE, Nilsson LO. Progress report on the continent ileostomy. World J Surg 1980; 4: 143-8

8 Dozois RR, Kelly KA, Beart RW Jr, Beahrs OH. Improved results with continent ileostomy. Ann Surg 1980; 192: 319-24

9 Goligher JC, Lintott D. Experience with 26 reservoir ileostomies. Br J Surg 1980; 62: 893-900

10 Palmu A, Sivula A. Kock's continent ileostomy: results of 51 operations and experiences with correction of nipple valve insufficiency. Br J Surg 1978; 65: 645-8

11 Fendel EH, Fazio VW. Construction of a continent ileostomy using a porcine aortic valve. Dis Colon Rectum 1982; 25: $21-3$

12 Schmidt E, Bruch HP. Traitement chirurgical des incontinences sphincterériennes intestinales par autotransplant libre de musculature lisse. J Chir (Paris) 1981; 118 : 315-20.

13 Schmidt E. The continent colostomy. World J Surg 1982; 6: 805-9

14 Centeno Neto AAC, Veyrac M, Briand D, Spilotis J, Saint Aubert B, Joyeux H. Autotransplantation of the pylorus sphincter at the terminal abdominal colostomy: experimental study in dogs. Dis Colon Rectum 1991; 34: 874-9.

15 Khubchandani IT, Trimpi HD, Sheets JA, Stasik JJ, Balcavage CA. The magnetic stoma device, a continent colostomy. Dis Colon Rectum 1981; 24: 344-50.

16 Husemann B, Hager TH. Experience with the Erlangen magnetic ring colostomy closure system. Int Surg 1984; 69: 297-300.

17 Tenney JB, Eng M, Graney MJ. The quest for continence. Dis Colon Rectum 1978; 21 : 522-33.

18 Alexander-Williams J, Amery AH, Devlin HB. Magnetic continent colostomy device. Br Med J 1977; 1: 1269

19 Prager E. The continent colostomy. Dis Colon Rectum 1984; 27: 235-7

20 Mouchizadeh J, Papanicolaou G, Fielding LP. Continent ileostomy simplified by mucosal serosal window. Dis Colon Rectum 1987; 30: 858-2

21 Burcharth F, Ballan A, Kylberg F, Rasmussen SN. The colostomy plug: a new disposable device for a continent colostomy. Lancet 1986; 2: 1062-3

22 Cerdán FJ, Diez M, Campo J, Barbero M, Balibrea J. Continent colostomy by means of a new one-piece diposable device. Dis Colon Rectum 1991; 34: 886-90 
23 Claque MB, Heald RJ. Achievement of stomal continence in one-third of colostomies by use of a new disposable plug. Surg Gynecol Obstet 1990; 170:390 (abstract)

24 Hoepfner MT, Kelly KA, Sarr MG. Pacing the canine ileostomy. Surgery 1988; 104: 476-81

25 Rosenberg PH, Geiss AC, Nelson RL. Model of intestinal continence using an implantable pulse generator and a myoprosthetic sphincter. TASA.1O 1989; 35: 222-5

26 Cavina E, Seccia M, Evangelista G. Neo-sphincter and neo-stomy. New surgical views for myoelectric stimulated continence. A clinical experience. Preliminary report. Am J Proctol Gastroenterol Colon Rectal Surgery 1982; 33: 16-9

27 Prochiantz. A. Myoplastic fessière a visée sphincteriénne, pour le traitement des incontinences fécales des agénésies sacrées et des malformations anorectales opérées. Chir Pédiatr 1979; 20:63

28 Williams NS. Anorectal reconstruction. Br J Surg 1992; 79: 733-4

29 Salmons S, Vrbova. G. The influence of activity on some contractile characteristics of mammalian fast and slow muscles. J Physiol (London) 1969; 201: 534-49

30 Pette D. Activity-induced fast to slow transitions in mammalian muscle. Med Sci Sports Exerc. 1984; 16: 517-28

31 Hallan RI, Williams NS. Hutton MRE, Scott M, Pilot MA, Swash M, Koeze TH, Watkins ES. Electrically stimulated sartorius neosfincter: canine model of activation and skeletal muscle transformation. Br J Surg 1990; 77: 208-13

32 Heine JA, Rothenberger DA, Wong WD, Williams JG, VanBergen EH, Buie WD, Goldberg SM. An electrostimulated skeletal muscle neosphincter in a canine model of fecal incontinence. Dis Colon Rectum 1992; 35: P8

33 Havenith MG, Visser R, Schrijvers van Schendel JMC, Bosman FT. Muscle fiber typing in routinely processed skeletal muscle with monoclonal antibodics. Histochemistry 1990; 93: 497-9

34 Boyd JB, Taylor GI, Corlett R. The vascular territories of the superior epigastric anteries and the deep inferior epigastric systems. Plast Reconstr Surg 1984; 73: 1-16

35 Moon HK, Taylor GI. The vascular anatomy of rectus abdominis musculocutaneous flaps based on the deep superior epigastric system. Plast Reconstr Surg 1988; 82: 815-29.

36 Budras KID. Zur angewandten Anatomie der ventralen Bauchwand des Schweines. Berl Munch Tierarzt Wochenschr 1969; 82: 147-51

37 Johnson MA, Polgar J, Weigthman D, Appleton D. Data on distrubution of fiber type in thirty-six human muscles. An autopsy study. J Neurol Sci 1973; 18:111-29

38 Schroder HD, Reske-Nielsen E. Fiber types in the striated urethral and anal sphincters. Acta Neuropathol. (Berl) 1983; 60: 278-82

39 Guelinckx PJ. Free microneurovascular muscle grafts: deficits resulting from transplantation and speculations for myocardial repair. J Card Surg 1991; 6: 190-4 



\section{Chapter 4}

\section{The feasibility of transposed and}

stimulated sartorius muscle to serve as a sphincter in dogs 


\subsection{INTRODUCTION}

Replacement or reconstruction of the sphincters is indicated for incontinent patients with a denervated or absent anal sphincter. A new sphincter can be constructed with a transposed skeletal muscle. The most common transposition procedure is the graciloplasty as described by Pickrell et al (1). The main artery, the innervation and the origin of the gracilis muscle remain undisturbed during this procedure. It has been argued that such a transposed gracilis muscle behaves as a Thiersch repair and induces an outlet obstruction only (2).

However, patients with gracilis slings are capable to contract this muscle and by doing so, to close their anal canal (3). A prolonged voluntary contraction of the transposed gracilis muscle is essential to maintain continence but may be a problem in daily practice (3). In addition, gracilis is by its nature unsuitable for sphincter function as the muscle consists in majority of type II, fatigue-prone muscle fibers (chapter 2).

Electrical stimulation induces a conversion in muscle composition from type II (fatigue-prone) into type I (fatigue-resistant) fibers which may allow a transposed fatigue-prone skeletal muscle to function as a fatigue-resistant sphincter (4-7). Hallan et al. demonstrated in their original study in dogs that a sartorius neosphincter is feasible. However, sartorius biopsies demonstrated patchy fibre necrosis and fatty infiltration after transposition and stimulation. A control (non-stimulated) transposed muscle was not used in their experiments (8). The aim of this study was to assess the morphology and function of an electrically stimulated neosphincter in a canine model and to compare these data with a control (non-stimulated) neosphincter in the same dog.

\subsection{MATERIAL AND METHODS}

\section{Animals and anaesthesia}

Five adult mongrel dogs have been used. Premedication consisted of Medetomidine (Domitor ${ }^{(}$, Farmos group Ltd, Turku, Finland). Anaesthesia was induced with Thiopental (Nesdonal ${ }^{\circledR}$, Rhône Mérieux, Lyon, France) and maintained after endotracheal intubation with a nitrous oxide, oxygen $(1: 2)$ halothane $(0.8 \%)$ (Trofields surgical A.G., Zug, Switzerland) mixture. Medetomidine was antagonized with Atipamezole (Antisedan ${ }^{\circledR}$, Farmos group Ltd, Turku, Finland). Gentamicin (Garamycin ${ }^{\circledR}$, AUV, Cuyck, The Netherlands) and Metronidazole (Flagyl ${ }^{\circledR}$, Rhône Poulenc bv, Amstelveen, The Netherlands) 
were given intravenously as antibiotic prophylaxis. The animals were treated according to Dutch legislation. These studies were approved by the animal ethical committee of the University of Limburg.

\section{Surgical procedures}

The canine sartorius was used because the gracilis muscle is not suited for sphincter construction in dogs (9). The sartorius muscle in dogs is a long flat muscle with a superior and inferior belly. The muscle has a proximal neurovascular pedicle and virtually the same vascularization as human gracilis muscle. During the operation, the superior belly of the sartorius muscle was dissected from the medial femoral fascia (above the patella) in the cranial direction until the neurovascular pedicle was found. The nerve entry point was visualized and at this position, an intramuscular electrode was placed as cathode (model SP 5528, Medtronic, Kerkrade, The Netherlands). A similar electrode was positioned as anode several centimeters distal to the cathode. These electrodes were tunneled and connected with an Itrel ${ }^{\mathrm{TM}}$ pulse generator (Medtronic, Minneapolis, USA) which was situated below the rectus muscle. The procedure was performed on the left as well as the right sartorius muscle (fig 1).

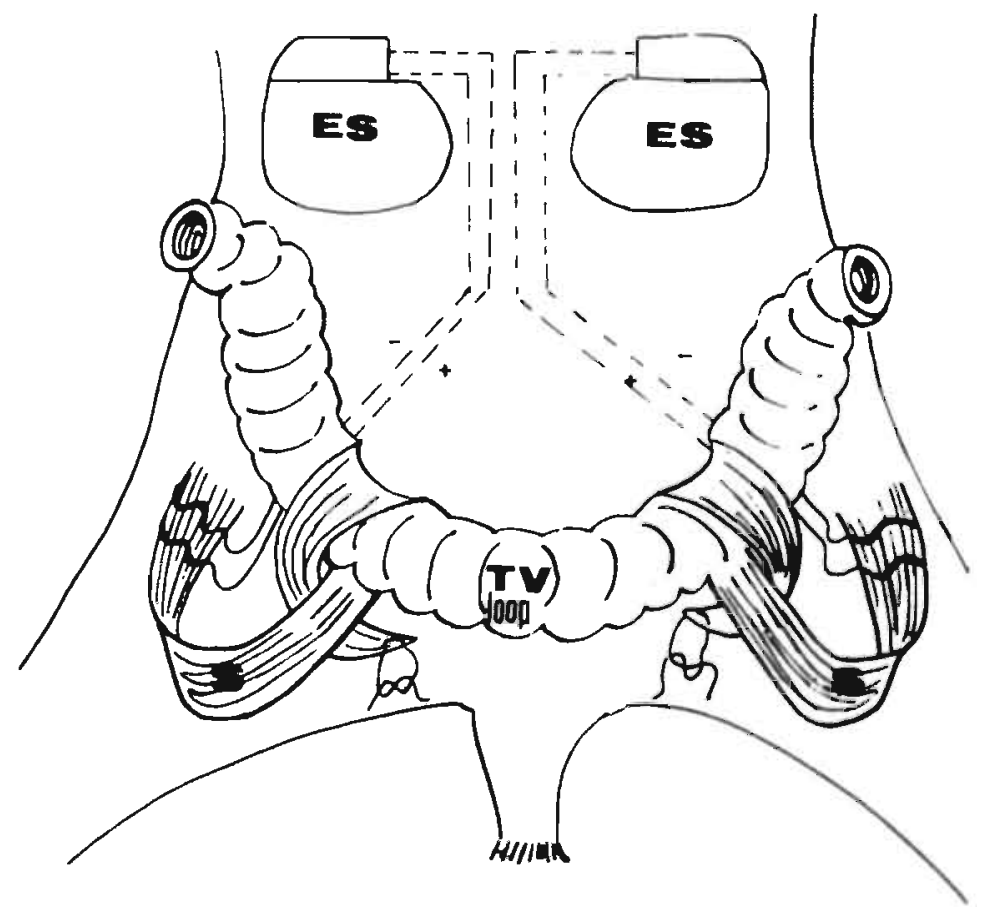

Figure 1, surgical procedure

$S=$ transposed sartorius muscle, ES = electrical stimulator, TV loop = Thiry Vella loop 
After dissection of the sartorius muscle and implantation of the stimulation device, a midline laparotomy was performed and a Thiry Vella loop of $15 \mathrm{~cm}$ jejunum was created, using a single layer hand sewn anastomosis with a monofilament suture (PDS, Ethicon ${ }^{\star}$, Germany). The transposed sartorius muscles were passed subcutaneously and wrapped around the distal end of the Thiry Vella loop and sutured to the anterior superior iliac spine as a new sphincter on the left as well as the right side (figure 1) to imitate a human graciloplasty as much as possible. The electrical stimulation was started 6 weeks after the operation in 1 transposed muscle. At that time, the muscle was thought to be recovered from manipulation and dissection. Randomization has been used to select the muscle, which was electrically stimulated while the other muscle served as a control. Stimulation was given intermittently with a frequency of 25 $\mathrm{Hz}$ during 8 weeks (table I) modified from a model used for the latissimus dorsi muscle in cardiomyoplasty (10) .

The stimulation parameters were adjusted, using an external programmer (Model 7432, Medtronic, Minnesota, USA). After completing the intermittent $(25 \mathrm{~Hz})$ electrical stimulation, continuous $(15 \mathrm{~Hz})$ electrical stimulation was programmed in order to assess if the physiological characteristics of the transposed and stimulated sartorius muscle had changed from those of a fast twitch, fatigue prone muscle into a slow twitch, fatigue resistant muscle (4). The voltage was gradually adapted during the training of 8 weeks to 2.75 volt because the voltage required to produce palpable and visual contractions is known to increase during electrical stimulation of dynamic myoplasties $(11,12)$.

\section{Evaluation: muscle morphology}

Biopsies were taken from the proximal muscle part: (i) during surgery $(t=0$ weeks), (ii) before electrical stimulation ( $t=6$ weeks) and after completing the stimulation program $(t=16$ weeks $)$ in order to assess: (i) a morphological

Table I, sartorius muscle stimulation protocol

\begin{tabular}{lllllll}
\hline time & $6-8$ & $8-10$ & $10-12$ & $12-14$ & $14-16$ & weeks \\
\hline $\begin{array}{llllll}\text { Parameters } \\
\text { "On" time }\end{array}$ & 0.125 & 0.125 & 0.125 & 1.5 & continuous & seconds \\
"off" time & 2 & 1 & 0.375 & 0.375 & 0 & seconds \\
duty cycle * & 6 & 11 & 25 & 80 & 100 & $\%$ \\
frequency & 25 & 25 & 25 & 25 & 15 & $\mathrm{~Hz}$ \\
\hline
\end{tabular}

* duty cycle is the percentage of time during which the output of the sartorius muscle is actually on. 
starting point (ii) the morphological consequences of transposition and (iii) the efficacy of stimulation. Control biopsies were obtained from non-stimulated muscles. In addition, biopsies were taken from the distal muscle at the top of the muscle wrap after completing the stimulation program. All muscle biopsies were paraffin embedded and fixed in formalin. The percentage and lesser diameter of type I fibers was assessed, using the monoclonal antibody RIIDi0 directed against the myosin heavy chain of type I muscle fibers (13). The percentage of endomysial collagen was measured after staining with Sirius Red $(14,15)$, using the Picrosirius Red-Polarization method $(14,15)$ and a computer assisted image analyzer (CAS 200, Becton Dickinson Inc, Lombard, Illinois, USA).

\section{Evaluation: retention times of the new sphincters}

The function of the new sphincters was assessed 6 weeks after surgery and after completion of the intermittent electrical training program. The retention time of saline flow through the Thiry-Vella loop was assessed by means of an urinary catheter to which a pressure was applied of $85 \mathrm{~cm}$ water with the pulse generator "off" and "on".

\section{Evaluation: manometry}

Manometry was performed with a Millar catheter (Millar Instruments, Houston, Texas, USA) connected to a recorder writer, using the stationary pull through method. The following tests were performed 6 and 14 weeks after surgery; (i) the lowest frequency during which the muscle had a fused contraction was determined and (ii) manometry of the new sphincter was performed with the stimulation device "on" and "off", 6 and 14 weeks after surgery.

Data were expressed as mean and $95 \%$ confidence intervals [C.I.]. Statistical analysis was performed using the Wilcoxon test with the computer program SPSS/PC+ (version 3.1)(Microsoft, Chicago, Illinois, USA). Results were considered significant if $\mathrm{P}<0.05$.

\subsection{RESULTS}

The post-operative recovery was normal in the 5 dogs studied and they had a normal kennel life.

\section{Muscle morphology}

The percentage of type I, fatigue-resistant muscle fibers increased from $41 \%$ before transposition (figure 2) to $46 \%$ after transposition ( $n=10$, mean increase $5 \%[-5,15]$, not significant). After the electrical training program, the biopsies of the stimulated sartorius muscle (figure 3 ) demonstrated a significant in- 


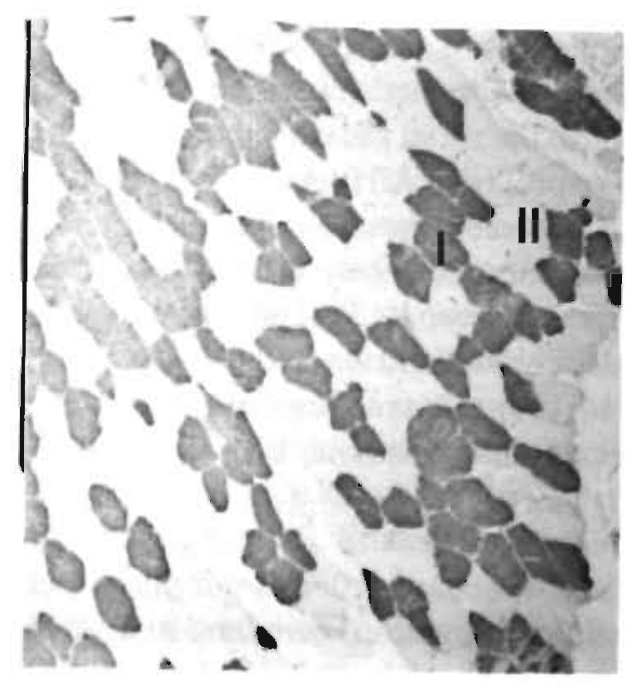

Figure 2, santorius before stimulatio Type I fibers stain dark with the monoclonal antibody RIIDI0 and are marked "I". original magnification $=\mathrm{X} 100$

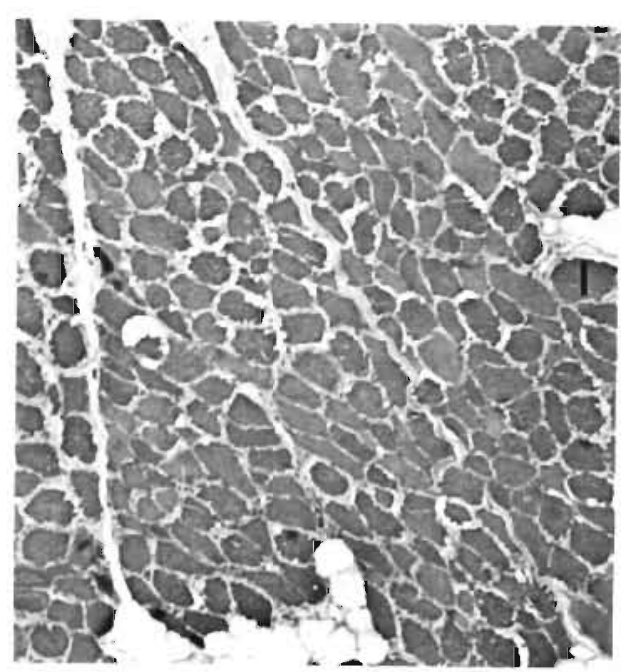

Higure 3, sartorius after stimulation

Type I fibers stain dark with the monoclonal antibody RIIDI0 and are marked "I". original magnification $=$ X 100

Table II, percentage type I fibers

\begin{tabular}{llcl}
$\begin{array}{l}\text { time } \\
\text { (weeks) }\end{array}$ & stimulated & control \\
\hline$t=0$ & surgery & $39[18,60]$ & $43[25,62] \%$ \\
$t=6$ & after transposition & $48[40,56]$ & $44[26,63] \%$ \\
$t=16$ & proximal biopsies & $* 78[55,101]$ & $49[38,60] \%$ \\
$t=16$ & distal biopsies & $* 81[60,102]$ & $52[40,64] \%$ \\
\hline
\end{tabular}

* $\mathrm{P}<0.05$ if compared with values at $\mathrm{t}=0$ and $\mathrm{t}=6$ weeks

Table III, diameter type I fibers

\begin{tabular}{llll}
\hline $\begin{array}{l}\text { time } \\
\text { (weeks) }\end{array}$ & & stimulated & control \\
\hline $\mathrm{t}=0$ & surgery & $39[31,46]$ & $41[37,44] \mu \mathrm{m}$ \\
$\mathrm{t}=6$ & after transposition & $33[24,42]$ & $35[29,42] \mu \mathrm{m}$ \\
$\mathrm{t}=16$ & proximal biopsies & $39[30,48]$ & $35[30,40] \mu \mathrm{m}$ \\
$\mathrm{t}=16$ & distal biopsies & $35[24,46]$ & $35[28,42] \mu \mathrm{m}$ \\
\hline
\end{tabular}




\begin{tabular}{lllr}
$\begin{array}{l}\text { time } \\
\text { (weeks) }\end{array}$ & stimulated & control \\
\hline $\mathrm{t}=0$ & surgery & $4.9[3.5,6.3]$ & $4.6[3.2,5.9] \%$ \\
$\mathrm{t}=6$ & after transposition & $7.7[5.1,10.3]$ & $* 7.6[5.4,9.8] \%$ \\
$\mathrm{t}=16$ & proximal biopsies & $8.9[5.1,12.7]$ & $6.3[3.9,8.7] \%$ \\
$\mathrm{t}=16$ & distal biopsies & $* 9.1[8.5,9.7]$ & $* 7.4[5.7,9.1] \%$ \\
\hline
\end{tabular}

* $\mathrm{P}<0.05$ if compared with values at $\mathrm{t}=0$ weeks

creased percentage of type I muscle fibers after stimulation whereas the percentage in the non-stimulated control muscle only slightly increased during 8 weeks (table II).

Transposition caused a decrease in muscle fibre diameter from $40 \mu \mathrm{m}$ before transposition to $34 \mu \mathrm{m}$ after transposition (mean decrease $6 \mu \mathrm{m}$ [2, 10], $\mathrm{n}=10$, $\mathrm{P}<0.05)$. Electrical stimulation induced no further decrease in muscle fiber diameter (table III).

Endomysial collagen increased from 4.8 before to $7.7 \%$ after transposition (mean increase $2.9 \%[1.3,4.5], \mathrm{n}=10, \mathrm{P}<0.05$ ). Thereafter endomysial collagen increased only slightly in the stimulated muscle (table IV).

Retention times in stimulated neosphincters

With the pulse generator "off" saline passed through the stoma's without hindrance and none of the sphincters inhibited flow. Retention times with the pulse generator "on" increased from $18[-6,42]$ before to $308[113,503] \mathrm{sec}$. after stimulation (mean increase $290[102,478] \mathrm{sec} ., \mathrm{n}=5, \mathrm{P}<0.05$ ) in electrically trained muscles.

Retention times of the control neosphincters

The non-stimulated sphincter showed a retention time of $217[-166,600] \mathrm{sec}$. before the intermittent training program was started in the other muscle and 531 sec. $[148,914], 8$ weeks later (mean increase $314[-408,1037]$ sec., $n=5, P=$ 0.29). 

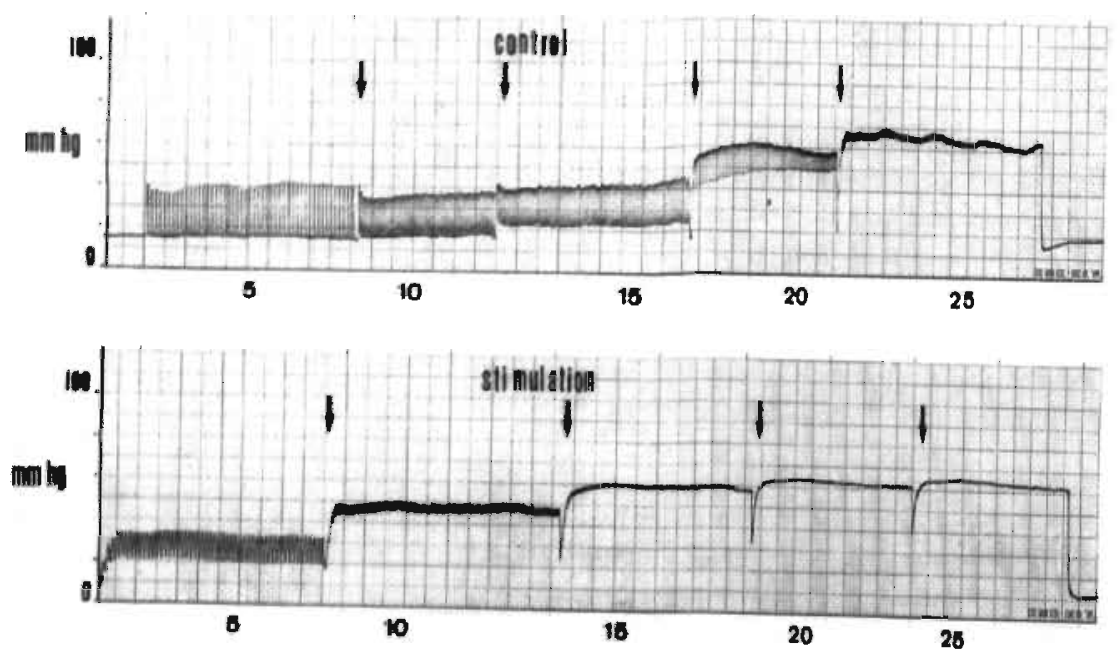

Flgure 4, minimum frequency which produced a fused contraction

On the $\mathrm{Y}$-axis the pressure of the new sphincter is expressed in $\mathrm{mm} \mathrm{Hg}$. On the $\mathrm{X}$-axis the stimulation frequency $(\mathrm{Hz})$ is displayed and indicated with arrows. The recording speed is 5 $\mathrm{mm} / \mathrm{second}$. These measurements were performed after 8 weeks electrical stimulation. The minimum frequency which caused a fused contraction was $25 \mathrm{~Hz}$ in the control muscles and $15 \mathrm{~Hz}$ in the muscle which had been electrically stimulated as demonstrated at the bottom of figure 4 .

Table $V$, manometry of stimulated and control sphincteroplasty

\begin{tabular}{|c|c|c|c|c|}
\hline \multicolumn{2}{|c|}{ time (weeks) } & \multirow{2}{*}{$\frac{\begin{array}{l}\text { stimulated } \\
(n=5)\end{array}}{14[4,24]}$} & \multirow{2}{*}{$\begin{array}{l}\begin{array}{l}\text { Control } \\
(\mathrm{n}=5)\end{array} \\
22[6,38] \\
* 78[39,117]\end{array}$} & \multirow[b]{2}{*}{$\begin{array}{l}\mathrm{mm} \mathrm{Hg} \\
\mathrm{mm} \mathrm{Hg}\end{array}$} \\
\hline$t=6$ & $\begin{array}{l}\text { stimulation "off" } \\
\text { stimulation "on" }\end{array}$ & & & \\
\hline $\mathrm{t}=14$ & $\begin{array}{l}\text { stimulation "off" } \\
\text { stimulation "on" }\end{array}$ & $\begin{array}{c}31[-7,69] \\
* 84[65,103]\end{array}$ & $\begin{array}{c}23[-6,52] \\
* 76[20,133]\end{array}$ & $\begin{array}{l}\mathrm{mm} \mathrm{Hg} \\
\mathrm{mm} \mathrm{Hg}\end{array}$ \\
\hline
\end{tabular}

\section{Manometry}

The minimum stimulation frequency which produced a fused contraction decreased from a mean of $24 \mathrm{~Hz}$ before stimulation to $16 \mathrm{~Hz}$ (figure 4) in electrically trained muscles (mean decrease $8 \mathrm{~Hz}[5,11], n=5, P<0.05$ ). The minimum stimulation frequency at which a fused contraction was obtained in control muscles remained unchanged $(22 \mathrm{~Hz}[19,25], \mathrm{P}=1)$. 
Pressures in the 10 new sphincters increased from $18 \mathrm{~mm} \mathrm{Hg}$ without stimulation to $75 \mathrm{~mm} \mathrm{Hg}$ with the stimulation device "on" (mean increase $57 \mathrm{~mm} \mathrm{Hg}$ $[35,78], \mathrm{n}=10, \mathrm{P}<0.01$ ) before stimulation and this increase was maintained after the stimulation program (table $\mathrm{V}$ ) in the control as well as the stimulated muscle. There was no change in resting pressures in the sphincters with the stimulation device "off" before and after the training program.

\subsection{DISCUSSION}

In our experiments, the proximal muscle biopsies demonstrated a decrease in fiber diameter after transposition and before the electrical training program was started. These morphological changes most likely are a consequence of transposition and support the hypothesis of Cavina et al. that transposition induces a modest atrophy in muscles which have been used for the construction of a neosphincter (16). The increased collagen content after transposition and before stimulation may be due to a lack of contractile activity as has been demonstrated in rabbits (17).

Electrical stimulation increased the percentage of type I, slow twitch, fatigue resistant muscle fibers significantly from 48 to $81 \%$, while it remained stationary in control muscles. A high percentage of type I fibers is characteristic for postural muscle and may therefore assist transposed sartorius to function as a fatigue-resistant sphincter in dogs (18). In addition, it has been demonstrated in rabbits that electrical stimulation increases oxidative enzyme activities which may allow a continuous fuel supply for stimulated muscles (19). A conversion from type II to type I muscle fibers is supported by the fact that the minimal stimulation frequency at which a fused contraction was found, could be reduced in electrically stimulated sphincters from $24 \mathrm{~Hz}$ before stimulation to $16 \mathrm{~Hz}$ after the training program. The minimal stimulation frequency which produced a fused contraction remained unchanged in control muscles.

Six weeks after surgery, retention times with the pulse generator turned "on", demonstrated a large variability as the stimulated neosphincter inhibited flow for $18 \mathrm{sec}$. while the control neosphincter inhibited flow for $217 \mathrm{sec}$., implicating that these 2 sphincters did not have identical properties before the electrical training program. This variability in retention times may have been caused by peristalsis in the Thiry Vella loop because we did not identify the oral and aboral ends of this loop. However, this does not seem very likely because saline passed through the Thiry Vella loop without hindrance if the pulse generator was switched "off". In addition, randomization was used to prevent bias between stimulated and control neosphincters. Fourteen weeks after surgery, retention 
time of saline increased not only with $290 \mathrm{sec}$. in the electrically trained neosphincters but also in the control neosphincters (with $314 \mathrm{sec}$ ). The increased retention times in the control neosphincter is probably due to the increased stimulation voltage (from 0.75 to 2.75 Volt) after 8 weeks. The increased stimulation voltage was previously determined in these experiments because the voltage required to achieve palpable muscle contractions is known to increase during electrical stimulation $(11,12)$. On the other hand, the control neosphincters did not contract for 8 weeks while the stimulated muscles were continuously activated. As a consequence, no manometry data and retention times were assessed after stimulation of the control neosphincters for some hours. However, if the control muscle was stimulated for 30 minutes (which has been performed in the final experiment in $1 \mathrm{dog}$ ), the retention time from this control neosphincter decreased from 410 to $200 \mathrm{sec}$. while the stimulated neosphincter in this dog was capable to inhibit the flow of saline for $470 \mathrm{sec}$., after 8 weeks continuous electrical stimulation. The lesser increase in retention time of the stimulated sphincter may also be due to electrical training as stimulation not only induces a transformation from fatigue prone into fatigue resistant muscle fibers but also reduces maximal tetanic tension (4).

Pressure registrations in the stimulated and control muscle were comparable, implicating that in our model there is no clear relation between retention times and pressure registrations. Buie et al. demonstrated a correlation between pressure and tightness of the sartorius wrap in dogs. In their experiments the tightness of the sartorius wrap was previously determined. However, they sutured the sartorius to itself and did not measure pressure in the sphincter but before the neosphincter in the bowel which may explain the difference between their data and our results $(20,21)$. Nevertheless, in patients with anal incontinence who are treated by gracilis muscle transposition, the tightness can be extremely important for the functional outcome although it may be concluded from Buie's and our experiments that it is difficult to control.

In conclusion: we demonstrated that the construction of a neosphincter is feasible with preservation of its morphological structure. Stimulation is inextricably linked to a transformation from type II, fatigue prone to type I, fatigue resistant muscle fibers and induces morphological and functional changes towards that of the external anal sphincter. characteristics (chapter 2). However, this transformation was not essential to increase the acute retention times of saline in our model of faecal continence. 


\section{References}

1 Pickrell KL, Broadbent TR, Masters FW, Metzger JT. Construction of a rectal sphincter and restoration of anal incontinence by transplanting gracilis muscle: a report of four cases in children. Ann Surg 1952; 135: 853-63

2 Corman ML. Gracilis muscle transposition for anal incontinence: late results. Br J Surg 1985; 72: S21-2

3 Christiansen J, Sørenson M, Ramussen $\emptyset$. Gracilis muscle transposition for faecal incontinence. Br J Surg 1990; 77: 1039-40

4 Salmons S, Henriksson J The adaptive response of skeletal muscle to increased use. Muscle Nerve 1981; 4: 94-105

5 Henriksson J, Chi MY, Hintz CS, Young DA, Kaiser KK, Salmons S, Lowry OH. Chronic stimulation of mammalian muscle: changes in enzymes of six metabolic pathways. Am J Physiol 1986; 251: C614-32

6 Salmons S, Scréter FA. Significance of impulse activity in the transformation of skeletal muscle type. Nature 1976; $263: 30-4$

7 Pette D, Müller W, Leisner E, Vrobvá G: Time dependent effects on contractile properties, fibre population, myosin light chains and enzymes of energy metabolism in intermittently and continuously stimulated fast twitch muscles of the rabbit. Pfluegers Arch 1975; 361: 1-7

8 Hallan RI, Williams NS, Hutton MRE, Scott M, Pilot MA, Swash M, Koeze TH, Watkins ES. Electrically stimulated sartorius neosphincter: canine model of activation and skeletal muscle transformation. Br J Surg 1990; 77: 208-13

9 Evans HE, Christensen GC. Muscles. In: Miller's anatomy of the dog. Philadelphia: WB Saunders company 1979; 387-91

10 Chacques JC, Grandjean PA, Carpentier A. Dynamic cardiomyoplasty: experimental cardiac wall replacement with a stimulated skeletal muscle. İn: Chiu RIC (editor). Biomechanical cardiac assist, cardiomyoplasty and muscle-powered devices. New York: Futura Publishing, 1986; 85-102

11 Lucas CMHB, Havenith MG, van der Veen FH, Habets J, Nagel van der T, Schrijversvan Schendel JM, Penn OCKM, Wellens HJJ. Changes in canine latissimus dorsi muscle during 24 weeks of continuous electrical stimulation. J Appl Physiol 1992; 73: 828-35

12 Heine JA (personal communications)

13 Havenith MG, Visser R, Schrijvers van Schendel JMC, Bosman FT. Muscle fiber typing in routinely processed skeletal muscle with monoclonal antibodies. Histochemistry 1990; 93: 497-9

14 Junquira LCU, Montes GS, Sanchez EM. The influence of tissue section thickness on the study of collagen by the picrosirius-Polarization method. Histochemistry 1982; 74 : 153-6

15 Dolber PC, Spach MS. Picosirius red staining of cardiac muscle following phosphomolybdic acid treatment. Stain Technol 1987; 62: 23-6

16 Cavina E, Evangelista G. Chiarugi M, Buccianti P, Tortora A, Chirico A. Perineal colostomy and electrical stimulated gracilis neosphincter after abdomino-perineal resection of the colon and anorectum: a surgical experience and follow-up study in 47 cases. Int J Colorect Dis 1990; 5: 6-11 
17 Williams PE, Canese T, Lucey EG, Goldspink G. The importance of stretch and contractile activity in the prevention of connective tissue accumulation in muscle. $J$ Anat 1988; 158: 109-14

18 Johnson MA, Polgar J, Weightman D, Appleton D. Data on distribution of fiber type in thirty-six human muscles. An autopsy study. J Neurol Sci 1973; 18: 111-29

19 Pette D, Smith ME, Staudte HW, Vrobva G. Effects of long-term electrical stimulation on some contractile and metabolic characteristics of fast rabbit muscles. Pflügers Arch 1973; 338: 257-72

20 Heine JA, Rothenberger DA, Wong WD, Williams JG, VanBergen EH, Buie WD, Goldberg SM. An electrostimulated skeletal muscle neosphincter in a canine model of fecal incontinence. Dis Colon Rectum 1992; 35: P4 (abstract)

2I Buie WD, Wong WD, Heine JA, Lowry AC, Madoff RD, Rothenberger DA. The effect of resting pressure and stimulation frequency on squeeze pressure in a canine electrostimulated stomal neosphincter. Surgical Forum XVII, 1992 


\section{Chapter 5}

Anal dynamic graciloplasty 


\subsection{INTRODUCTION}

An extensive loss of the anal sphincter function may be repaired by gracilis muscle transposition or one of its modifications (1-18). Results of graciloplasty have been disappointing in the past, as continence requires a voluntary and prolonged contraction of the transposed gracilis muscle (16). Dickson et al. and Cavina et al. demonstrated that electrical stimulation (with implanted electrodes) can make such a transposed gracilis muscle contract independently of will $(2,18)$. But, the gracilis consists in majority of type II, fast-twitch, fatigue-prone fibers which are not suited for sphincter function (chapter 2). Long-lasting contraction of a transposed skeletal muscle can be achieved in dogs via implanted intramuscular electrodes in order to achieve a high pressure zone in the bowel which induces continence (chapter 4). The feasibility of this approach in incontinent patients has been demonstrated by Williams et al. and Baeten et al.(19-22). We denoted the procedure as "anal dynamic graciloplasty". The indications for the procedure are patients with faecal incontinence in whom conventional surgery failed or was contraindicated $(21,22)$. The aim of this chapter is to report the efficacy of this new treatment modality in a case control series of 33 consecutive patients in which the alternative would be a permanent colostomy.

\subsection{PATIENTS AND METHODS}

\section{Patients}

Between November 1986 and October 1992, 33 patients with faecal incontinence for solids and liquids ( 23 female and 10 male) were treated with anal dynamic graciloplasty. The median age was 44 years (range 18 to 70 ). The cause of virtually complete incontinence was due to anal atresia in 9 patients (2 patients had a cut-back and 7 patients a pull through procedure), trauma in 11 patients (obstetric trauma $(n=3)$, fistula repair $(n=5)$, sphincterotomy $(n=1)$, Lord procedure $(n=1)$ and spondylodesis $(n=1)$ ), lower motor-neuron lesion in two patients (spina bifida and cauda equina syndrome) and primary neurogenic incontinence in 11 patients. Three patients had a colostomy. Previous anal surgery was performed in 25 patients but failed (table $\mathrm{I}$ ) and was contraindicated in the other patients. Three of these patients had a gracilis muscle transposition performed some years ago, but remained incontinent. The median time of incontinence was 16 years (range 2 to 40 ). 
Table I, previous treatment modalities in connection with the cause of incontinence

\begin{tabular}{lllll}
\hline \multicolumn{2}{l}{ patients } & & \\
\cline { 2 - 5 } & $\begin{array}{l}\text { anal atresia } \\
(\mathrm{n}=9)\end{array}$ & $\begin{array}{l}\text { trauma } \\
(\mathrm{n}=11)\end{array}$ & $\begin{array}{l}\text { motor lesion } \\
(\mathrm{n}=2)\end{array}$ & $\begin{array}{l}\text { neurogenic } \\
(\mathrm{n}=11)\end{array}$ \\
\hline $\begin{array}{l}\text { anal repair } \\
\text { post-anal repair }\end{array}$ & 4 & & 2 \\
$\begin{array}{l}\text { conventional graciloplasty } \\
\text { biofeedback } \\
\text { other procedures }\end{array}$ & 2 & 2 & 7 \\
$\begin{array}{l}\text { medical treatment and/or (post)- } \\
\text { anal repair contraindicated }\end{array}$ & 5 & 3 & & \\
\hline
\end{tabular}

*rerouting $(n=1)$, levatorplasty $(n=1)$ and Wreden Stone procedure $(n=1)$

**3 patients with an obstetric trauma had an immediate sphincter repair

\section{Gracilis muscle transposition}

The graciloplasty was performed according to the technique described by Pickrell (5). A single incision (about $25 \mathrm{~cm}$ ) was used to identify and mobilize the gracilis muscle instead of 3 small incisions. In addition, we used 2 incisions lateral to the anus and blunt finger dissection to create a subcutaneous tunnel around the anal canal. Systemic antibiotics (Metronidazole (Flagyl ${ }^{\circledR}$, RhônePoulenc, Amstelveen, The Netherlands), Guramycin (Gentamicin ${ }^{\circledast}$, Essex bv, Amstelveen, The Netherlands) and Flucloxacillin (Floxapen ${ }^{\circledR}$, Beecham farma bv, Amstelveen, The Netherlands)) were administered before and 24 hours after the operation. No colostomies were used and in 3 patients a previously constructed colostomy was temporarily left in place during the procedures. To ensure that the gracilis muscle and its innervation had remained in good condition, its contractility was evaluated after minimally 4 weeks by transcutaneous electrical stimulation. Contractions of the transposed gracilis muscle were tested by rectal palpation.

\section{Implantation of the stimulation equipment}

Minimally six weeks after the transposition, the site of lowest threshold of the graciloplasty was defined using transcutaneous electrical stimulation. During surgery, an incision was made at this spot and the optimal electrode position was determined, using testing needles connected to an external stimulator. Two similar electrodes (SP 5528, Medtronic, Kerkrade, The Netherlands) were woven into the muscle. Firstly, the anode was placed in the distal gracilis muscle part at the side of the anal canal. Thereafter, the nerve entry zone was determined and at this site the cathode was positioned in the muscle. Subsequently the 
movable insulation sheaths were secured and the electrode leads were subcutaneously tunneled to the lower abdominal wall and connected with an Itrel ${ }^{\mathrm{TM}}$ pulse generator (Medtronic, Kerkrade, the Netherlands), which was placed in a subcutaneous pocket ( $\mathrm{fig} 1$ ) in the abdominal wall. In the last 15 patients, the pulse generator and electrodes were immersed in a Garamycin solution and topical Garamycin was used to prevent infections.

\section{Stimulation of the graciloplasty (anal dynamic graciloplasty)}

Stimulation was started immediately after implantation of the pulse generator employing a pulse width of 210 microseconds, in a cyclic mode with an "on" time of 0.125 seconds and an "off" time of 2 seconds, yielding a duty cycle of $6 \%$ (the time during which the muscle is actually contracting). The frequency within the bursts was $25 \mathrm{~Hz}$. Subsequently, the duty cycle was gradually increased during 8 weeks (as described in chapter 4). Thereafter continuous stimulation was used. The stimulation voltage was set to the individual need for a good contraction of the transposed gracilis muscle. In the first patient a slightly different stimulation protocol was applied as previously described (19). An external magnet was used by all patients to tum the mode of operation of the pulse generator "off" to permit defaecation. The same magnet was used to reactivate the pulse generator immediately after defaecation.

\section{Clinical evaluation}

The use of diapers and the frequency of bowel emptying per 24 hours were recorded before and after 8 weeks stimulation. The retention time of a $250 \mathrm{ml}$. phosphate enema was assessed before electrical stimulation and after 8 weeks of stimulation. The enema was given and the time of first leakage was noticed by the patient and the observer. The time to postpone defaecation was recorded

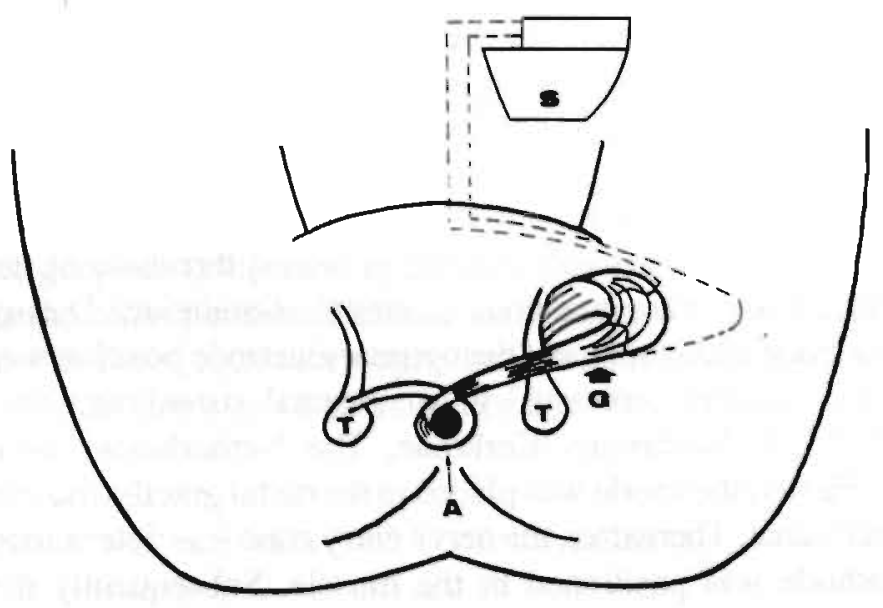

Figure 1, the gracilis muscle is transposed from the left leg and wrapped around the anal canal. $G=$ graciloplasty, $\mathrm{S}=$ stimulator, $\mathrm{T}=$ ischial spine, $\mathbf{A}=$ anal canal 
by the patient before and after 8 weeks of stimulation. In addition, the functional outcome was assessed by means of a standardized scoring method as described by Williams et al (21).

\section{Electromyography and anal manometry}

Neurophysiological evaluation was used to assess the pudendoanal reflex and to perform electromyographic evaluation of the external anal sphincter and the gracilis muscle before transposition. To investigate the anal canal pressure, a Konigsberg microtransducer (Konigsberg Inc, Pasadena, CA, USA) connected to a computer assisted Polygraph (Synectics Medical, Stockholm, Sweden) was used before transposition. The patient was lying in a right lateral position with knees and hips flexed to 90 degrees and resting and squeeze pressure were measured by using the stationary pull through method (23). Anal manometry was repeated after transposition and implantation of the stimulation equipment. The effect of electrical stimulation on the contractions of the transposed gracilis muscle was evaluated with manometry again and pressure was measured with pulse generator "on" and "off". When the rise in anal pressure was less than 20 $\mathrm{mm} \mathrm{Hg}$, an adjustment in stimulation voltage was made. The stimulation frequency which produced a fused contraction of the transposed gracilis muscle was assessed before and 8 weeks after stimulation.

\section{Defaecography}

Defaecography was performed as described by Goei et al. (24). A conventional graciloplasty and/ or a dynamic graciloplasty might have an influence upon the minimal diameter of the anal canal. This diameter was therefore measured during squeeze, rest and straining (and corrected for the magnification factor): (i) before gracilis muscle transposition (ii) six weeks after transposition and (iii) 16 weeks after stimulation.

\section{Gracilis muscle composition}

Gracilis muscle biopsies were obtained in open biopsies from 9 patients before electrical stimulation and minimally 16 weeks later. In these biopsies, fiber typing was done on $4 \mu$ meter sections (formalin fixed and paraffin embedded) which were incubated with the monoclonal antibody R11D10 (Centocor Europe, Leiden, The Netherlands). This antibody binds to myosin heavy chains of type I fibers and is therefore capable to identify these fibers (25). The antibody is specific for type I fibers and does not bind to type II fibers. The proportion of the type I muscle fibers was expressed as percentage of total fibers counted in each section. The lesser diameter of these fibers was determined, using an interactive image analysis system (MOP, Videoplan Kontron, Eching/München, FRG). In each section at least hundred muscle fibers were analyzed. The Picrosirius Red-Polarization method was used to stain collagen $(26,27)$. Four 
$\mu$ meter sections were incubated in aqueous phosphomolybdic acid for 5 minutes. This was followed by staining in $0.1 \%$ Sirius red F3BA (C.I. 35780, Polysciences, Northampton, UK), in saturated aqueous picric acid (90 minutes). Thereafter, the sections were rinsed with $0.01 \mathrm{~N}$ HCL. Sirius red staining was measured in 25 sights of view, using an computer assisted image analyzer (CAS 200, Becton Dickinson Inc, Lombard, Illinois, USA). Positive staining was expressed as percentage of the total area measured.

Data were expressed as mean and $95 \%$ confidence intervals [CI]. Statistical analysis was performed using the Student's-t-test for paired data and the Kruskal-Wallis test for analysis between groups with the computer program SPSS/PC+ (version 3.1)(Microsoft, Chicago, lllinois, USA). Results were considered significant if $P<0.05$. These studies were approved by the medical ethical committee of Maastricht University Hospital.

\subsection{RESULTS}

\section{Clinical results}

Median follow-up is now 10 months ( $n=33$, range 8 weeks, 6 years). None of the patients achieved continence with gracilis muscle transposition alone. After implantation of the stimulation equipment, continence was achieved in 21 (64\%) patients and these patients did not use diapers any longer ( 2 of these 21 patients developed a wound-infection which required removal of the stimulation device but one of these patients achieved continence without stimulation and the other patient became continent after re-implantation). Infection after implantation of the stimulation device necessitated removal of the electrodes and pulse generator in 3 other patients (fig 2). The 5 infections were seen in the first 18 patients. No further infections were noticed in the last 15 patients (in which we immersed the pulse generator and electrodes in a Garamycin solution and used topical Garamycin).

An anal fistula developed in 1 patient without perineal and anal sensibility due to a spina bifida as the stimulated gracilis muscle perforated the anal canal after 16 weeks. In this patient a colostomy was constructed. Other failures were encountered in 7 cases; one patient had a non distending rectum due to a frozen pelvis and in 6 patients contractions of the proximal part of the transposed gracilis muscle were difficult to palpate and to measure with manometry although the proximal part of the gracilis showed good contractions. Two of these patients received a colostomy and another patient still has a previously constructed colostomy. The incontinence frequency per 24 hours decreased from a mean of 5 before stimulation to a controlled defaecation 2 times a day, 8 weeks 


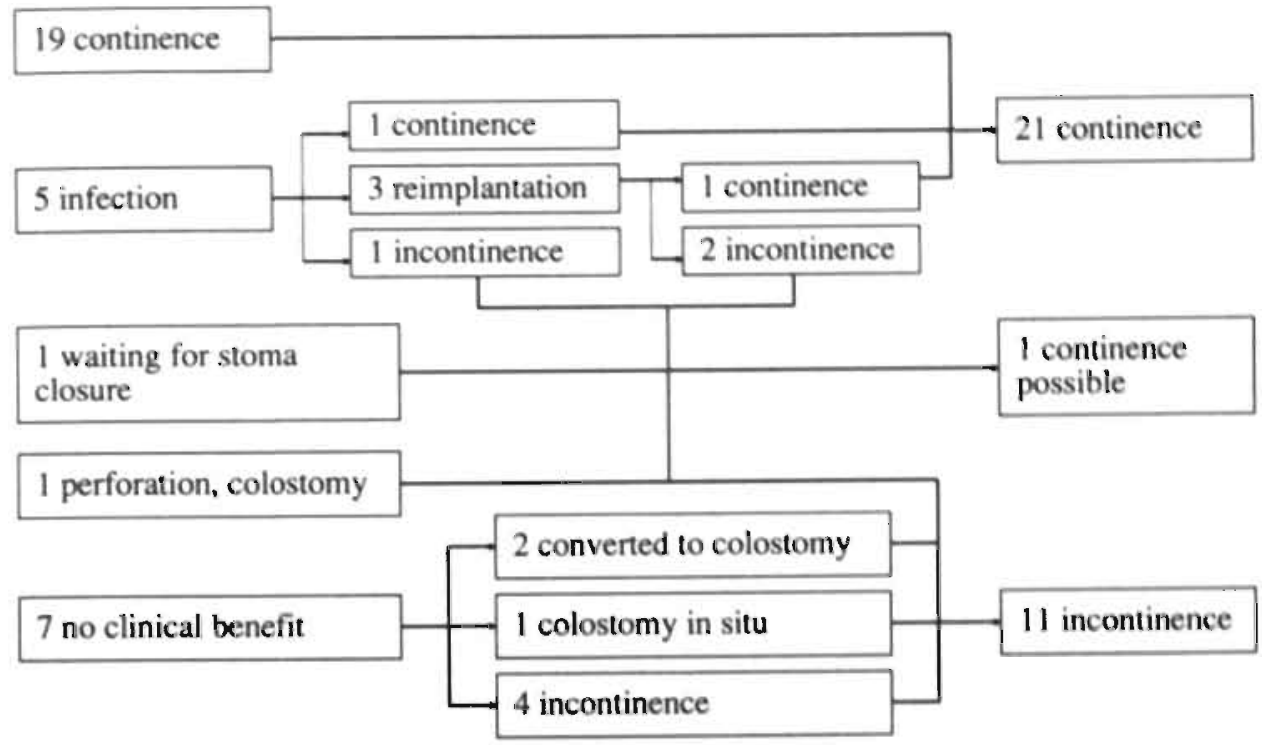

Figure 2, the clinical outcome is shown of the 33, patients. One patient is waiting for stoma closure.

later (mean decrease 2 times [1,3], $\mathrm{n}=30, \mathrm{P}<0.01$ )(Three patients had a previously constructed colostomy in situ during the electrical training period). Retention time of the $250 \mathrm{cc}$ phosphate enema increased from 53 seconds before gracilis muscle stimulation to 199 seconds after 8 weeks of stimulation (mean increase $146[74,218] \mathrm{sec}$., $\mathrm{n}=33, \mathrm{P}<0.01)$. The time to postpone defaecation increased from a mean of $9 \mathrm{sec}$. before stimulation to $13 \mathrm{~min}$. after 8 weeks of stimulation (mean increase 13 min $[6,20], n=30, P=0.08$ ). The functional outcome in connection with the cause of incontinence is listed in table II.

\section{Electromyography and anal manometry}

Preoperative electromyography revealed a total or almost total degree of denervation of the extemal sphincter in all patients. After transposition, transcutaneous electrical stimulation proved that all the gracilis muscles remained vital. Subsequently, a stimulator was implanted in all patients. Manometry before transposition demonstrated a low anal resting pressure of 33 $[26,39] \mathrm{mm} \mathrm{Hg}$ as well as a low squeeze pressure $45[38,51] \mathrm{mm} \mathrm{Hg}$ before transposition (fig 3).

After graciloplasty, resting and squeeze pressure measured $37[31,43]$ and 71 $[63,78] \mathrm{mm} \mathrm{Hg}$ respectively but the time of contraction was limited to a maximum of 1 minute and not sufficient to achieve continence. 
Table II, continence category in connection with the cause of incontinence after anal dynamic graciloplasty

\begin{tabular}{lllll}
\hline & \multicolumn{2}{l}{ patients } & & \\
\cline { 2 - 5 } category * & $\begin{array}{l}\text { anal atresia } \\
(\mathrm{n}=9)\end{array}$ & $\begin{array}{l}\text { trauma } \\
(\mathrm{n}=11)\end{array}$ & $\begin{array}{l}\text { motor lesion } \\
(\mathrm{n}=2)\end{array}$ & $\begin{array}{l}\text { neurogenic } \\
(\mathrm{n}=11)\end{array}$ \\
\hline I & 5 & 3 & 1 & 2 \\
II & 1 & 6 & & 4 \\
III & 3 & 1 & 1 & 2 \\
IV & 56 & 1 & 1 & 3 \\
V & 52 & 82 & 50 & 55 \\
\hline
\end{tabular}

* I = continent to solids, liquids and flatus, $\mathrm{II}=$ continent to solids and liquids but not flatus, III = continence to solids but occasional episodes of liquid incontinence, IV $=$ occasional episodes of solids and frequent episodes of incontinence of liquids, $\mathrm{V}=$ frequent episodes of incontinence of solids and liquids

"* all patients had a preoperative score of "V". Success was defined as categories I and II. No significant differences were found, using the Kruskal Wallis test.

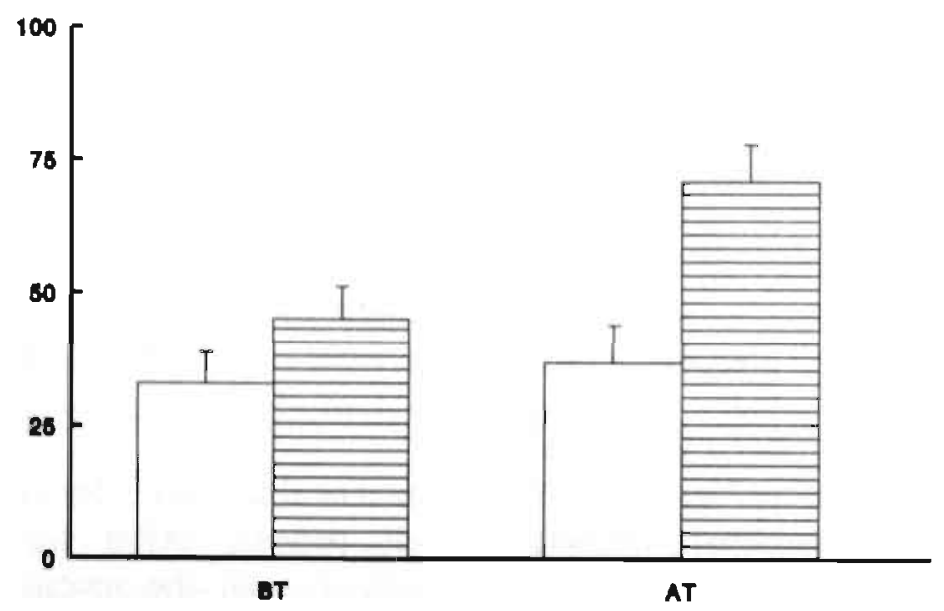

Figure 3, manometry before and after gracilis muscle transposition

On the $\mathrm{Y}$-axis the mean anal pressure and $95 \%$ confidence intervals are displayed in $\mathrm{mm} \mathrm{Hg}$. BT on the $\mathrm{X}$-axis displays the (resting and squeeze) anal pressure Before Transposition of the gracilis muscle, whereas AT illustrates the mean anal pressure After Transposition of the gracilis muscle. The resting pressure is expressed as a white bar while the squeeze pressure is displayed as the vertical shaded bar. Data of 30 patients are shown because 3 patients had performed a graciloplasty some years ago. 


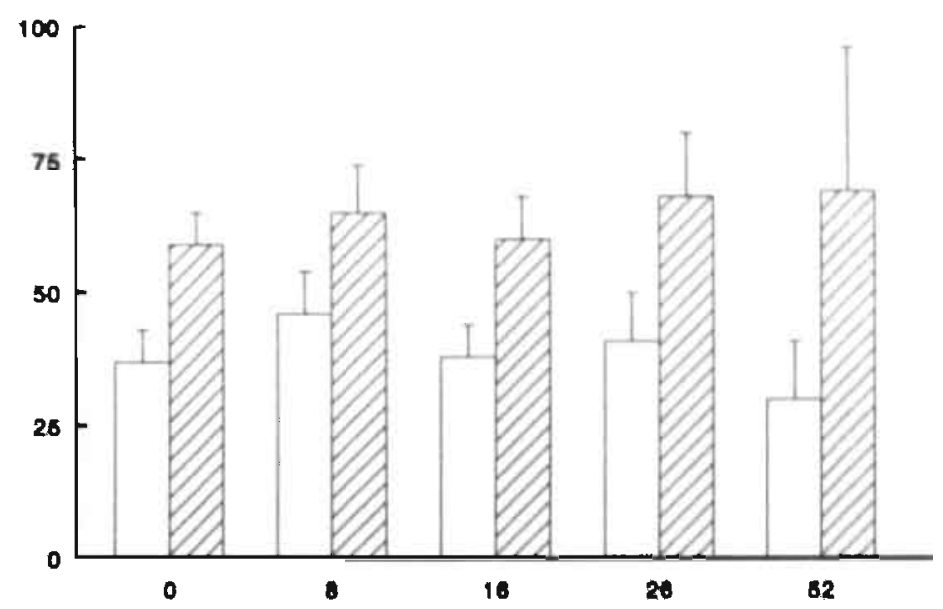

Figure 4, manometry with the pulse generator "off" and "on"

The competence of gracilis muscle stimulation is shown after implantation of the stimulation equipment. On the $\mathrm{Y}$-axis the mean anal pressure and $95 \%$ confidence intervals are displayed in $\mathrm{mm} \mathrm{Hg}$. On the $\mathrm{X}$-axis time after implantation of the stimulation device is demonstrated (weeks). The pressure without stimulation is expressed as a white bar while the pressure with the pulse generator "on" is shown as an oblique shaded bar. Stimulation increased the anal pressure significantly during 52 weeks $(\mathrm{P}<0.05)$ although it was necessary to increase the stimulation voltage (table 3). Data of 33 patients are shown after 8 weeks, 25 patients are shown after 16 weeks because 3 patients have not evaluated so far and complications necessitated removal of the devices in 5 patients. In addition, 9 more patients have yet not been evaluated for 26 weeks because two of these were converted to a colostomy and 7 other patients have not been followed-up so far. Seven patients have been followed up for 1 year.

The implanted stimulator increased sphincter tone significantly (fig 4) over a prolonged period of time in all patients and faecal continence was obtained in 21 of the 33 patients. One patient is waiting for stoma closure. No technical failures of the stimulation equipment (for instance electrode fracture) were found.

Dynamic graciloplasty elicited a constant increase in anal pressure because even after 26 weeks electrical stimulation still increased anal pressure from $40 \mathrm{mnn}$ $\mathrm{Hg}$ without stimulation to $69 \mathrm{~mm} \mathrm{Hg}$ with stimulation (mean increase $27[18,36]$ $\mathrm{mm} \mathrm{Hg}, \mathrm{n}=16, \mathrm{P}<0.01$ ). The voltage required to elicit this sphincter tone increased significantly from 1.5 Volts at the start of stimulation to 2.9 Volts after 26 weeks (mean increase $1.4[1.0,1.8], \mathrm{N}=16, \mathrm{P}<0.01$ ), but stabilized more or less at 12 months (table III).

The minimum frequency found to produce a fused subtetanic (smooth) contraction could be reduced from $25 \mathrm{~Hz}$ before stimulation to $15 \mathrm{~Hz}$ after eight weeks of stimulation in all patients (fig 5). 
Table III, stimulation voltage

\begin{tabular}{lll}
\hline time (weeks) & voltage $(v)$ & patients $(\mathrm{N})$ \\
\hline 0 & $1.5[1.3,1.7]$ & 33 \\
8 & $2.2[1.9,2.5]^{*}$ & 33 \\
16 & $2.5[2.0,3.0]^{*}$ & 25 \\
26 & $2.9[2.3,3.5]^{*}$ & 16 \\
52 & $2.7[2.0,3.4]^{* *}$ & 7 \\
\hline
\end{tabular}

During the first 26 weeks the stimulation voltage increased significantly if compared with the mean stimulation voltage at $\mathrm{t}=0$ weeks $(* \mathrm{P}<0.01$ ). Thereafter, the voltage stabilized (** $\mathrm{P}>0.5$ ). Data of 33 patients are shown after 8 weeks, 25 patients are shown after 16 weeks because 3 patients have not evaluated so far and complications necessitated removal of the devices in 5 patients. In addition, 9 more patients have yet not been evaluated for 26 weeks because two of these were converted to a colostomy and 7 other patients have not been followed-up so far. Seven patients have been followed up for 1 year.

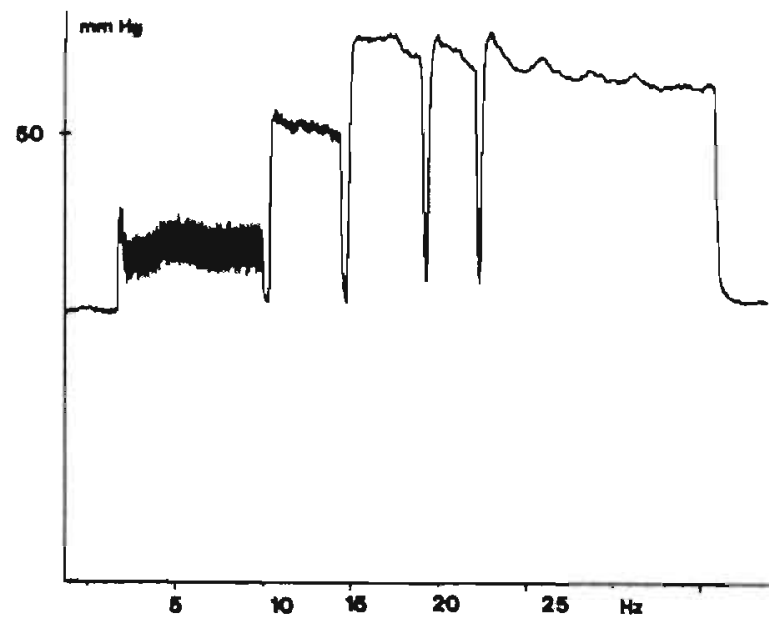

Figure 5, on the $\mathrm{Y}$-axis pressure is expressed as $\mathrm{mm} \mathrm{Hg}$. On the $\mathrm{X}$-axis the stimulation frequency $(\mathrm{Hz})$ is displayed. The recording speed is $5 \mathrm{~mm} / \mathrm{sec}$. The measurement was performed after 8 weeks stimulation. The minimum frequency which caused a fused contraction was $15 \mathrm{~Hz}$.

\section{Defaecography}

Defaecography demonstrated unsatisfactory function of the anal sphincter in all patients before gracilis muscle transposition (fig 6). The minimal diameter of the anal canal decreased from $0.6 \mathrm{~mm}$ before gracilis muscle transposition to 0.2 $\mathrm{mm}$ with the pulse generator "on", 16 weeks later (fig 7). 


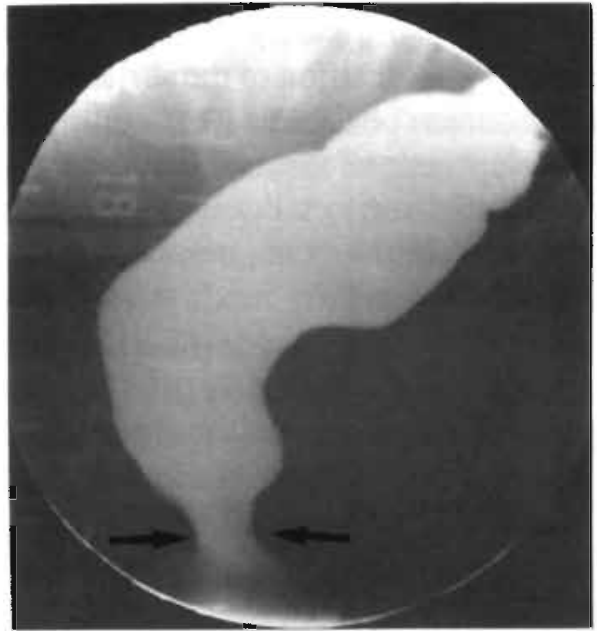

Figure 6, defaecography before transposition Figure 7, defaecography after implantation The arrows are indicating the minimal The arrows are indicating the minimal diameter the anal canal

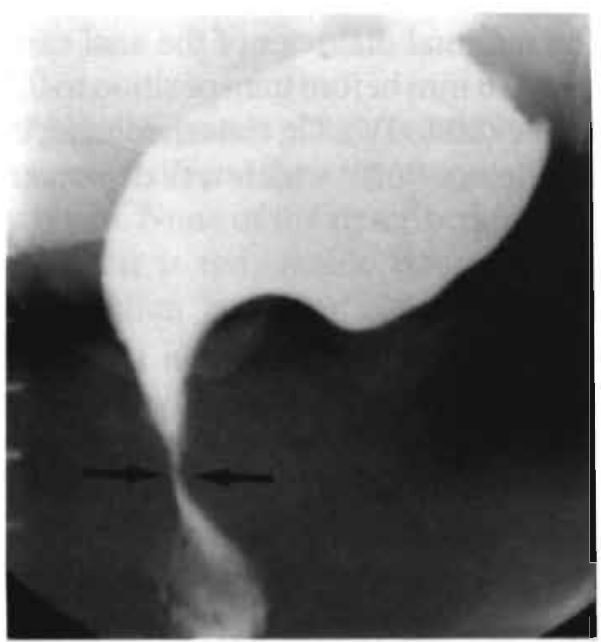
diameter the anal canal

Table IV, defaecography

\begin{tabular}{|c|c|c|c|c|}
\hline & squeeze & rest & straining *tr & $n$ \\
\hline $\begin{array}{l}\text { before gracilis } \\
\text { transposition }\end{array}$ & $0.6[0.4,0.7]$ & $0.6[0.5,0.8]$ & $0.9[0.8,1.0]$ & 29 \\
\hline $\begin{array}{l}\text { after gracilis } \\
\text { transposition }\end{array}$ & $* 0.3[0.2,0.4]$ & $* 0.4[0.3,0.5]$ & $* 0.6[0.5,0.8]$ & 32 \\
\hline $\begin{array}{l}\text { after implantation of } \\
\text { the stimulation device }\end{array}$ & $* 0.2[0.1,0.3]$ & $* 0.2[0.1,0.3]$ & $0.5[0.4,0.7]$ & 25 \\
\hline
\end{tabular}

The minimal diameter of the anal canal $(\mathrm{mm})$ is expressed as mean and $95 \%$ confiderice intervals [C.I.], * $=\mathrm{P}<0.05,{ }^{* *}$ straining after implantation of the stimulation device was done with the stimulation device "off". Data of 29 patients are shown before gracilis muscle transposition because three patients had a graciloplasty some years ago and in one patient no defaecography was performed before transposition. After gracillis muscle transposition, data of 32 patients are shown because one patient had no defaecography after transposition. After implantation of the stimulation device, data of 25 patients are shown because defaecography could not be repeated as a consequence of complications in 4 patients. Four other patients are waiting for further radiological evaluation. 
The minimal diameter of the anal canal decreased significantly during squeeze from $0.6 \mathrm{~mm}$ before transposition to $0.2 \mathrm{~mm}$ after implantation of the stimulation device (table IV). On the other hand, defaecation was possible with the stimulation device "off" which was demonstrated by opening of the anal canal during straining.

\section{Muscle biopsies}

Muscle biopsies showed an increase from $46 \%$ type I muscle fibers before stimulation (fig 8) to $64 \%$ type I fibers after electrical stimulation (fig 9)(mean increase $18 \%[13,23], n=9, P<0.01)$ (table $V$ ).

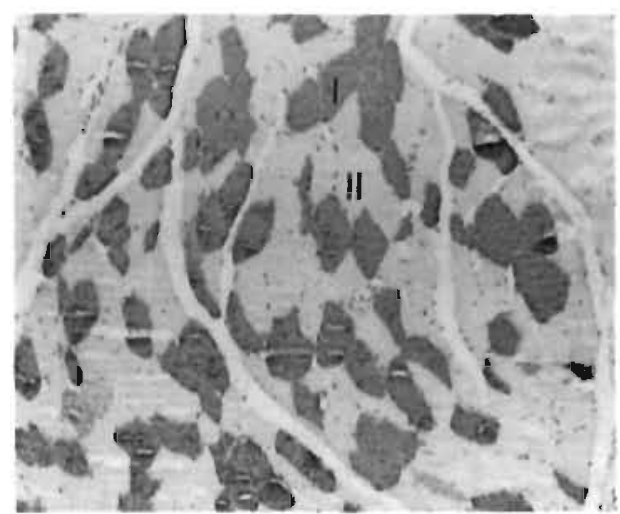

Figure 8, gracilis before stimulation Type I fibers stain dark with the monoclonal antibody RIIDI0 and are marked "I". Type II muscle fibers are marked "II". Original magnification $=$ X 100 .

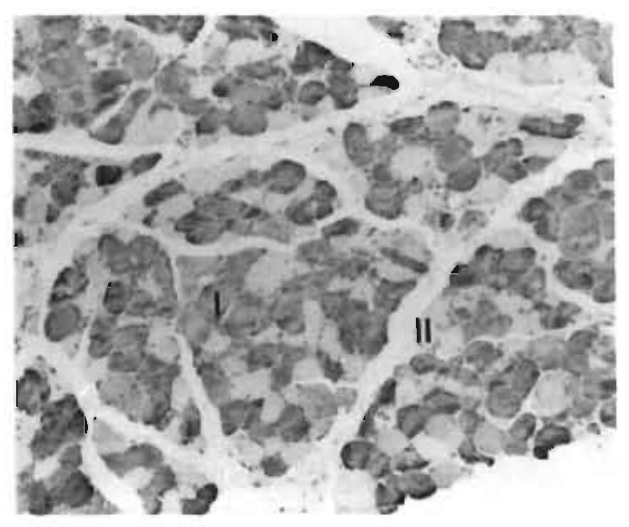

Figure 9, gracilis after stimulation

Type I fibers stain dark with the monoclonal antibody RIIDI0 and are marked "I". Type II muscle fibers are marked "II". Original magnification $=$ X 100 .

Table $\mathbf{V}$, results of muscle biopsies

gracilis before stimulation

$46[42,51]$
$32[27,38]$
$4[3,5]$

$46[42,51]$

diameter $(\mu \mathrm{m})$

collagen $(\%)$
$4[3,5]$ gracilis after stimulation
$64[58,71]^{*}$
$29[25,33] * *$
$6[5,8] *$

* $P<0.01$, ** not significant 


\subsection{DISCUSSION}

Our findings show that treatment with dynamic graciloplasty is much more successful than graciloplasty alone because it offers the opportunity for a prolonged muscular contraction for many hours. None of the described patients achieved continence without stimulation and it is remarkable how previous attempts without continuous electrical stimulation had even limited success $(13,16,17,21)$.

Several observations in our patients prove that there is a type II (fast twitch, fatigue prone) to type I (slow twitch, fatigue resistant) muscle fiber conversion in the stimulated gracilis: firstly, the percentage of type I fibers increased from 46 to $64 \%$, secondly the muscle could function for a prolonged period of time and lastly, the minimum stimulation frequency at which a fused contraction was obtained could be reduced from 25 to $15 \mathrm{~Hz}$.

The continuous stimulation of transposed gracilis muscle is needed to maintain a prolonged contraction, which is essential for restoration of the high pressure zone in the anal canal and of faecal continence. Incontinence returns when stimulation is discontinued because patients cannot contract a graciloplasty for a sustained period of time. The latter was demonstrated in the patients with an infection because withdrawal of the stimulation device was associated with return of incontinence. In addition, there is a reverse transformation from slow-twitch, fatigue-resistant fibers to fast twitch, fatiguable fibers (28). Our morphological studies in patients demonstrated that prolonged electrical stimulation of a transposed skeletal muscle causes a transformation from type II fatigue prone, into type I fatigue resistant muscle fibers.

Success was achieved in $64 \%$ of our patients (figure 1) and 1 patient is waiting for stoma closure. We noticed a higher (but not significant) success $(82 \%)$ in patients in whom incontinence was due to a trauma (table 2) which may be due to an intact innervation of the anorectum. Given the nature of the anatomical deformity and sometimes an ectatic rectum in patients with imperforate anus, the lower success rate $(56 \%)$ in these patients can be explained. The functional outcome $(55 \%)$ in patients with primary neurogenic incontinence can be explained because these patients have not only a denervated sphincter (which can be replaced with a dynamic graciloplasty) but also pelvic floor motor neuropathy and a sensory deficit of the anal canal (29). The occurrence of infections (15\% of the patients) after the implantation of the electrodes and the pulse generator is an important cause of failure and a major point of concern. The first half of the patients had implanted the electrodes and pulse generator without immersion in a Garamycin solution and we noticed a high infection rate ( 5 of 18 patients). 
In the last 15 patients, we immersed the electrodes and pulse generator in a Garamycin solution and used topical Garamycin which reduced the occurence of infections radically $(0 \%)$.

In 6 patients (18\%), distal gracilis muscle did not sufficiently contract after implantation of the stimulation device which emphasizes the vulnerability of this part of gracilis muscle (30). Moreover, it is difficult to assess during surgery how taut the gracilis wrap around the canal should be.

Gracilis muscle transposition has been reported to act as a passive resistance against the passage of bowel contents in patients who suffer from faecal incontinence $(15,17)$. In this study however, defaecography demonstrated a decrease in the minimal diameter of the anal canal after transposition but continence was not achieved. Electromyography in these studies proved that the muscle remained vital after transposition. Therefore, muscular contractions of the transposed gracilis muscle may restore a high pressure zone (as demonstrated by manometry and defaecography) and restore continence. If these muscular contractions are induced by an implanted stimulation device, the morphology of the muscle changes in the direction of the external anal sphincter which allows dynamic graciloplasty to function as a sphincter.

The stimulation device was implanted six weeks after transposition because: (i) simultaneous implantation and transposition are by necessity performed in a contaminated area, despite the fact that the electrodes and pulse generator were implanted far from the anal canal, (ii) transposition of the gracilis muscle may damage blood supply and the muscle may need time to recover from surgery (31) and (iii) electrical stimulatior induces an increased metabolic demand of the gracilis muscle which may augment the likelihood of gracilis muscle necrosis if the stimulation is started immediately $(32,33)$.

In this study intermittent electrical stimulation with a frequency of $25 \mathrm{~Hz}$ during 8 weeks has been used for the following reasons; firstly, the intermittent stimulation protocol proved to be safe in other human applications like for instance dynamic cardiomyoplasty (34); secondly, the physiological frequency found to produce fused contractions in human gracilis muscle was $25 \mathrm{~Hz}$; and lastly continuous stimulation at a low frequency $(2-10 \mathrm{~Hz})$ does not provide fused contractions and thereby precludes closure of the anal canal and improvement of continence during the training period $(20,21)$.

Electrical stimulation can be performed with different techniques. The nerve trunk itself or its branches within the muscle are stimulated (denoted as intramuscular stimulation). Intramuscular stimulation increases stability of the 
electrodes and avoids damage to the nerve branches. On the other hand, direct stimulation of the main trunk decreases the stimulation voltage needed for muscular contractions (35). Dynamic graciloplasty requires a life long stimulation of transposed muscle to maintain the induced fiber changes and a tonic contraction. Intramuscular stimulation was applied to ensure stability of the electrodes. The stimulation voltage had to be increased (table 1) after the implantation which can be due to: (i) the transformation from type II to type I muscle fibers, which allows a prolonged contraction but simultaneously decreases contraction force (32), (ii) sorne electrode displacement resulting in an increased electrode nerve branch distance (iii) or progressive fibrosis around the electrodes. To maintain an adequate anal pressure, an increased voltage is necessary but this stimulation voltage stabilized after 1 year.

In the near future, other new treatment modalities will be developed for faecal incontinence. The inferior part of the gluteus maximus muscle is also suitable to create a dynamic sphincter (chapter 2). At present, the feasibility of stimulation and transposition of part of the gluteus muscle is assessed in animal models and incontinent patients $(36,37)$. A prospective randomized trial is necessary to select the most optimal muscle for dynamic sphincteroplasties. On the other hand, free muscle transplantation (and stimulation) with surgical anastomosis of nerves and vessels might be another approach to create a sphincter for the treatment of faecal incontinence at any side (38). Another prospective randomized trial is indicated to assess the feasibility of the artificial sphincter which consists of an inflatable cuff, which is positioned around the upper anal canal. The cuff can be filled with fluid from an implanted reservoir and occludes the anal canal. Excellent short term results have been reported $(39,40)$. These randomized trials may be executed in a relatively simple fashion by recording clinical data as medication, soiling and diaper use.

The measurements described in this thesis are indicated to assess the feasibility and mechanism of a new approach but such anorectal measurements have no strict relationship with clinical outcome $(24,41)$. In the patients described in this chapter, a quality of life study is performed because these new and expensive techniques need to be evaluated in a broader setting than from a clinical point of view only (42).

In conclusion, anal dynamic graciloplasty is capable of replacing the damaged sphincters and to substitute the anal sphincter function in $64 \%$ of the patients (in addition, 1 patient is waiting for stoma closure). This was demonstrated by clinical results, manometry, defaecography and muscle biopsies. The occurrence of infection during the implantation in a potentially contaminated anal region and the vulnerability of the distal gracilis muscle are the main causes of 
failure of the technique. Anal dynamic graciloplasty is a most suitable technique to achieve continence in patients who would have no other therapeutical options than the construction of a colostomy. The technique of transposed and stimulated skeletal muscle deserves wider application and offers a new perspective for treatment of faecal incontinence. 


\section{References}

I Pickrell KL, Broadbent TR, Masters FW. Metzger JT: Construction of a rectal sphincter and restoration of anal continence by transplanting the gracilis muscle: report of four cases in children. Ann Surg 1952; 135: 853-62

2 Dickson AS, Nixon $\mathrm{HH}$. Control by electronic stimulator of incontinence after operation for anorectal agenesis. J Pediatr Surg 1968; 3: 696-701

3 Simonsen OS, Stolf NAG, Aun F, Raia A, Habr-Gama A. Rectal sphincter reconstruction in perineal colostomies after abdominoperineal resection for cancer. Br J Surg 1976; 63: 389-91

4 Hartl H. Modifiziente Gracilisplastik. Paediatrie und Paedologie 1972; 2: 99-107

5 Pickrell KL, Georgiade N, Richard EF, Morris F. Gracilis muscle transposition for the correction of neurogenic rectal incontinence. Surg Clin North Am 1959: 39: 1405-15

6 Yoshioka K. Keighley MRB. Clinical and manometric assessment of gracilis muscle transplant for fecal incontinence. Dis Colon Rectum 1988; $31: 767-9$

7 Sonnino RE, Reinberg O, Bensoussan AL, Laberge JM, Blanchard H. Gracilis muscle transposition for anal incontinence in children: long tem follow-up. J Pedtr Surg 1991: 10: 1219-23

8 Shiuh Ma, Shun-Yan Leu, Rong-Hwang Fang. Reconstruction of the anorectal angle after abdominoperineal resection of rectum and anus-an animal model. Ann Plast Chir 1989; $23: 519-22$

9 Mercati U, Trancanelli V, Castagnoli P, Mariotti A, Ciaccarini R. Use of the gracilis muscles for sphincteric construction after abdominoperineal resection. Dis Colon Rectum 1991; 34: 1085-9

10 Cormann ML. Follow up evaluation of gracilis muscle transposition for fecal incontinence. Dis Colon Rectum 1980; 8: 552-5

11 Cormann ML. Anal Incontinence In: Colon and rectal surgery. Philadelphia: Lippingcot, 1984; 116-38

12 Cormann ML. The management of anal incontinence. Surg Clin N Am 1983; 63: 177-91

13 Cormann ML. Follow-up evaluation of gracilis muscle transposition for faecal incontinence. Dis Colon Rectum 1980; 23: 552-5

14 Cormann ML. Management of fecal incontinence by gracilis muscle transposition.

Dis Colon Rectum 1979; 22: 290-2

15 Cormann ML. Gracilis muscle transposition for anal incontinence: late results. Br J Surg 1985; 72: S21-2

16 Christiansen J, Sørenson M, Ramussen $\varnothing \varnothing$ : Gracilis muscle transposition for faecal incontinence. Br J Surg 1990; 77: 1039-40

17 Leguit P, Baal van JG, Brummelkamp WH. Gracilis muscle transposition for fecal continence. Long tern follow-up and evaluation of anal pressure recordings. Dis Colon Rectum 1985; 28: $1-4$

18 Cavina E, Evangelista G, Chiangi M, Buccianti P, Tortora A, Chirico A. Perineal colostomy and electrically stimulated gracilis neosphincter after abdomino-perineal resection of the colon and anorectum: a surgical experience and follow-up study in 47 cases. Int J Colorect Dis 1990; 5: 6-11

19 Baeten C, Spaans F, Fluks A: An implanted neuromuscular stimulator for fecal continence following previously implanted gracilis muscle. Dis Colon Rectum 1988; 31 : 134-7 
20 Williams NS, Hallan RI, Koeze TH, Pilot MA, Watkins S. Construction of a neoanal sphincter by transposition of the gracilis muscle and prolonged neuromuscular stimulation for the treatment of faecal incontinence. Ann Roy Coll Surg 1990; 72: 108-13

21 Williams NS, Patel J, George RD, Hallan RI, Watkins ES. Development of an electrically stimulated neoanal sphincter. Lancet 1991; 338: $1166-9$

22 Baeten CGMI, Konsten J, Spaans F, Visser R, Habets AMMC, Bourgeois IM, Wagenmakers AJM, Soeters PB. Dynamic graciloplasty for treatment of faecal incontinence. Lancet $1991 ; 338: 1163-5$

23 Keighley MRB, Henry MM, Bartolo DCC, McC Mortensen NJ. Anorectal physiology measurement: report of a working party. Br J Surg 1989; 76: 356-7

24 Goei R. Anorectal function in patients with defecation disorders and asymptomatic subjects. Radiology 1990; 74: 121-3

25 Havenith MG, Visser R, Schrijvers van Schendel JM, Bosman FT. Muscle fiber typing in routinely processed skeletal muscle with monoclonal antibodies. Histochemistry 1990; 93: 497-9

26 Junquira LCU, Montes GS, Sanchez. EM. The influence of tissue section thickness on the study of collagen by the picrosirius-Polarization method. Histochemistry 1982; 74: 153-64

27 Dolber PC, Spach MS. Picrosirius red staining of cardiac muscle following phosphomolybdic acid treatment. Stain Technol 1987; 62: 23-6

28 Eisenberg BR, Brown JMC, Salmons S. Restoration of fast muscle characteristics following cessation of chronic stimulation. Cell Tissue Res 1984; 238: 221-30

29 Rogers J, Henry MM, Misiewicz JJ. Combined sensory and motor deficit in primary neuropathic faecal incontinence. Gut $1988 ; 29: 5-9$

30 Starke J, Braun J, Gruwez J, Schumpelick V. Transposition des Musculus Glutaeus maximus zum Sphincterersatz bei analer Inkontinenz. Chirurg 1992: 63; 56-61

31 Patel J, George B, Sanahan D, Watkins ES, Williams NS. Improvement in viability of the gracilis neoanal sphincter after delayed transposition. Eur Surg Res 1991; 23: 90 (abstract)

32 Pette D, Vrbova G. Adaptation of mammalian skeletal muscle fibers to chronic electrical stimulation. Rev Biochem Pharmacol 1992; 120: 115-202

33 Lucas CMHB, Dubelaar ML, van der Veen FH, Kloosterman-Castro Ravelo E, Havenith MG, Habets J, van der Nagel T, Wellens HJJ. A new stimulation protocol for cardiac assist using the latissimus dorsi muscle. Pace 1992; 15: 561 (abstract)

34 Chachques JC, Grandjean PA, Carpentier A: Dynamic Cardiomyoplasty: experimental cardiac wall replacement with a stimulated skeletal muscle. In Cardiomyoplasty and muscle-powered devices. RCJ Chiu, editor. New York, Futura Publishing, 1986: 59-84

35 Malek AM, Mark RG. Functional electrical stimulation of the latissimus dorsi for use in cardiac assist. IEEE Trans Biomed Eng 1989: 36; 781-8

36 Guelinckx P. Personal communications

37 Devesa JM, Vicente E, Eniquez. JM, Nuno J, Bucheli P, Blas G, Villanueva MG. Total fecal incontinence-A new method of gluteus maximus transposition: preliminary results and report of previous experience with similar procedures. Dis Colon Rectum 1992; 35 : 339-49

38 Guelinckx P. Free microneurovascular muscle grafts: deficits resulting from transplantation and speculations for myocardial repair. J Card Surg 1992; 6 (suppl): 190-5

39 Wong WD, Rothenberger DA, Bartolo DCC. An artificial sphincter for anal incontinence. Dis Colon Rectum 1992; 35: P4 
40 Christiansen J, Sparse B. Treatment of anal incontinence by an implantable prosthetic anal sphincter. Ann Surg. 1992; 215 : 383-6

41 Felt Bersma JF, Klinkenberg Knol EC, Meuwissen SGM. Anorectal function investigations in incontinent and continent patients. Dis Colon Rectum 1990; 33: 479-85

42 Adang EMM, Engel GL, Konsten J, Baeten CGMI. Quality of life after dynamic graciloplasty, first results. Theor Surg (accepted) 


\section{Chapter 6}

\section{GENERAL DISCUSSION}




\section{General discussion}

In this thesis, a new treatment modality for faecal incontinence has been described: skeletal muscle transposition with intact neurovascular supply and subsequent implantation of intramuscular electrodes and a pulse generator. Such an electrically stimulated sphincteroplasty restores a high pressure zone in the anal canal and may thus restore continence. However, continence is not only a matter of sphincteric action but bowel peristalsis, sensation in the anal canal and rectum and rectal compliance may be of equal importance. In our opinion, sensation and compliance can not contribute to continence if there is no holding force at the bowel's end. For that reason, in this thesis we focus on the restoration of the sphincteric mechanism only. We demonstrated that dynamic sphincteroplasties are capable to create such a holding force in chapter 4 and 5 .

Intramuscular electrodes and a pulse generator are foreign bodies and as a consequence inferior to surgical procedures which use autologous material only. However at present the only feasible option using autologous material is stoma construction. A colostomy offers the incontinent patients the opportunity to improve normal life but nevertheless has substantial untoward consequences for social life and freedom of movement. Another treatment modality for incontinent patients with an absent or denervated sphincter is the implantation of an artificial sphincter (a silicone cuff surrounding the anal canal which can be inflated to occlude the bowel). Excellent short term results of the artificial sphincter have been reported but long-term follow-up is essential because infection and erosion of the bowel wall may compromise long term clinical results.

In the near future, physiology of normal continence will be further explored, allowing insight in what causes the urge to defaecate. It may then become feasible to restore continence in a more physiological way. Now, some patients remain incontinent despite a successful dynamic graciloplasty and restoration of the holding force. For these patients it can be important to develop sensation like devices which can eventually activate bowel peristalsis to induce defaecation. 
In addition, it may be essential to find treatment modalities which improve rectal compliance. Meanwhile, we will try to further develop "more perspectives for treatment of faecal incontinence". The feasibility of dynamic graciloplasty is assessed in growing animals to extend the applications of this technique in incontinent paediatric patients.

The construction of a stoma in patients with low rectal cancer (who need sphincter resection to cure their disease) may be avoided in the future. After an abdominoperineal resection, it is technically feasible to construct a perineal stoma with the distal colon. The sphincter mechanism can be restored by transposition of 2 gracilis muscles as one of these muscles can replace the puborectal sling while the other serves as a sphincter. The use of 2 electrically stimulated graciloplasties may restore continence in these patients who otherwise would be converted to a permanent stoma. Finally, dynamic musculoplasties offer a good accessible model to develop new treatment modalities for faecal and urinary incontinence. 


\section{Summary and conclusions}

In chapter 1 and 2 the various components of faecal continence are described. Continence should be considered as the balance between propulsive and holding forces. As a consequence, the etiology of faecal incontinence may rely on various factors which disturb this balance. A conservative approach to patients with faecal incontinence seems justified because alterations in stool consistency, rectal sensation, sensitivity of the anal canal can be influenced by medication, biofeedback and diet. These treatment modalities may result in improved faecal continence.

However, patients with faecal incontinence and a severely damaged, denervated or even an absent anal sphincter should be treated with surgery in order to restore the holding forces. When biofeedback or anal repair are contraindicated, these patients can be treated with; (i) construction of a stoma, (ii) an artificial sphincter and (iii) skeletal muscle transposition with intact neurovascular supply around the anal canal. The construction of a colostomy may diminish the embarrassing and disturbing consequences of faecal incontinence but still has an often untoward effect on private and intimate social life. The results of the artificial sphincter (a silicone cuff which surrounds the anal canal and which can be inflated to occlude the bowel) are promising but long term follow-up is essential because infection and erosion of the bowel wall may compromise long term results. Skeletal muscle transposition around the anal canal (graciloplasty) with undisturbed neurovascular supply has been used since nearly 40 years with varying success. Such a transposed muscle needs to be contracted voluntarily during a prolonged period of time in order to restore faecal continence. However, a sustained contraction requires a considerable amount of concentration and is therefore difficult to maintain. In addition, skeletal muscles consist in majority of type II, fast-twitch, fatigue prone fibers. Electrical stimulation with implanted electrodes not only causes contraction of skeletal muscle, but also induces a transformation from type II, fast-twitch, fatigue prone muscle fibers to type I, slow-twitch, fatigue resistant muscle fibers. Transposition and electrical stimulation of a transposed skeletal muscle may create a new dynamic structure which functions as a neosphincter. The procedure's limitations are mainly of anatomical nature; intact neurovascular supply and complete surrounding of the bowel may be essential for continence. 
In chapter 3, the anatomy of the human rectus muscle in three cadaver dissections was studied and it was found that transposed rectus abdominis muscle might be positioned as a new sphincter (sphincteroplasty). Nexi, the feasibility of this approach was assessed in 6 pigs and rectus muscle was positioned as a sphincter around a Thiry Vella loop. The use of 3 different surgical procedures has been assessed; (i) a muscular ring of the proximal rectus was conistructed which partly denervated the muscle, (ii) the distal end of the Thiry Vella loop was pulled through the middle of the rectus muscle thereby also introducing partial muscle denervation and (iii) a sling was constructed, using the distal muscle part. In 4 of these 6 pigs identical procedures were performed also at both sides. These new sphincters were electrically stimulated (with intramuscular electrodes and an implanted pulse generator) to study the feasibility of prolonged sphincter contraction. Stimulation with a frequency of $25 \mathrm{~Hz}$ was used at the right and $2 \mathrm{~Hz}$ at the left sphincters. We found that electrical stimulation with a frequency of 25 as well as $2 \mathrm{~Hz}$ increased the percentage of type I (relative fatigue resistant) muscle fibers significantly from 42 to $65 \%$ $(\mathrm{N}=6)$ in right and 50 to $67 \%(\mathrm{~N}=4)$ in left rectus in the innervated areas of the neosphincters. Stoma continence was not achieved becaluse constructing muscular rings and muscle splitting caused partial denervation and subseguently atrophy. Construction of a sling, using the distal part of the rectus did not show substantial atrophy, but continence was not achieved because the dorsal side of the Thiry-Vella loop was not completely covered with muscle fibers.

In chapter 4, a canine model for faecal continence is described. In each dog, both sartorius muscles were dissected and positioned as 2 neosphincters around a Thiry Vella loop. One of these neosphincters was electrically stimulated while the other served as a control. Fourteen weeks after surgery, the function of the neosphincters was assessed with the inflow of saline from a height of $85 \mathrm{~cm}$. With the pulse generator "off" saline passed through the stomata without hindrance and none of the sphincters inhibited flow. The mean retention time: increased in electrically stimulated neosphincters from 18 (before electrical stimulation) to $308 \mathrm{sec}$. after stimulation (mean increase $290[102,478] \mathrm{sec}, \mathrm{n}=5$, $\mathrm{P}<0.05$ ). The percentage of type $\mathrm{I}$, fatigue resistant muscle fibers increased from 48 to $84 \%$ in electrically stimulated sartorius muscles and remained equally in control muscles. Continuous electrical stimulation invariably caused transformation from type II, fatigue prone in type I, fatigue resistant muscle fibers. The latter induces a histological pattern in a transposed sartorius muscle not unlikely that of the external anal sphincter in humans.

In chapter 5, the feasibility of dynamic graciloplasty (transposition of the gracilis muscle and subsequent implantation of intramuscular electrodes and a pulse generator) to restore continence was assessed in a prospective study of 33 
patients with incapacitating faecal incontinence. The procedure was evaluated by; (i) clinical parameters, (ii) anal manometry and (iii) morphology of the transposed gracilis muscle. It was shown that dynamic graciloplasty is capable to restore faecal continence in 21 of the 33 patients $(64 \%)$ while 1 patient is waiting for closure of a previously constructed colostomy. Anal manometry demonstrated a significant increase in pressure from $38 \mathrm{~mm} \mathrm{Hg}$ (without stimulation) to $59 \mathrm{~mm} \mathrm{Hg}$ with the pulse generator "on" (mean increase 22 $[15,29] \mathrm{mm} \mathrm{Hg}, \mathrm{n}=33, \mathrm{P}<0.01$ ). The percentage of type-I, fatigue resistant muscle fibers increased from $46 \%$ before to $64 \%$ after electrical stimulation (mean increase $18[13,23] \%, n=9, P<0.01$ ). Failures were mainly due to infections and a non-contracting distal gracilis muscle. Simplification of the implanted intramuscular electrodes and pulse generator may reduce the infection rates and careful surgical handling of the distal gracilis may improve a favorable outcome. Simple electrical training programs and telemetry procedures are mandatory before the procedure can be used on a wider scale. Nevertheless, conversion of a conventional graciloplasty to a dynamic graciloplasty restores continence in $64 \%$ of the patients and prevents the construction of a colostomy. 


\section{Samenvatting en conclusies}

In hoofdstuk 1 en $\mathbf{2}$ worden verschillende aspecten van continentie besproken. Continentie is een evenwicht tussen uitdrijvende krachten en krachten die feces kunnen tegenhouden. Deze balans kan verstoord raken door verschillende oorzaken met als gevolg obstipatie of fecale incontinentie. Een behandeling met een dieet, biofeedback of geneesmiddelen lijkt dan ook bij iedere patiënt met

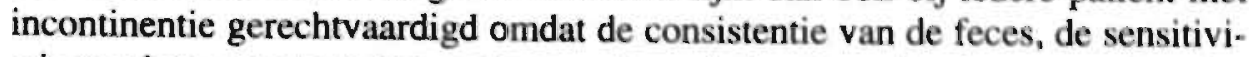
teit van het rectum en het anale kanaal en de krachten die feces tegenhouden beïnvloed kunnen worden. Dit kan de continentie herstellen.

Bij patiënten met incontinentie als gevolg van een afwezige, gedenerveerde of beschadigde sluitspier bestaat er een indicatie voor chirurgische interventie. Indien biofeedback of een overlappings plastiek van de beschadigde sfincter gecontraïndiceerd zijn, kan dit kan gebeuren door de constructie van een colostoma, de implantatie van een kunststof sluitspier (die bestaat uit een siliconen manchet rond het anale kanaal die kan worden opgeblazen) of het transponeren van een skeletspier vanuit het bovenbeen rond het anale kanaal. De constructie van een stoma biedt patiënten de mogelijkheid opnieuw deel te nemen aan het sociale leven maar kan ook resulteren in een andere perceptie van het eigen lichaam. De resultaten van de kunststof sluitspier zijn op korte termijn uitstekend. Op langere termijn kunnen infecties en erosie van het anale kanaal complicaties veroorzaken en daarom is langdurige follow-up geïndiceerd. Skeletspiertranspositie vanuit het bovenbeen rond het anale kanaal heeft als doel een nieuwe sluitspier te construeren. Deze conventionele techniek heeft helaas een wisselend succes. Het probleem is dat een dergelijke neosfincter actief moet worden aangespannen om fecale continentie te bereiken. Patiënten zijn echter niet in staat gedurende langere tijd de concentratie op te brengen die noodzakelijk is voor een dergelijke vrijwillige spiercontractie. Stimulatie met geìmplanteerde elektroden en een elektrische stimulator ondervangt het probleem van een bewuste contractie en kan de relatief snel vermoeide type II vezels van een skeletspier omvormen tot type I vezels die in staat zijn tot langdurige contracties. De combinatie van skeletspier transpositie en elektrische stimulatie kan daarom een nieuwe sfincter creëren. De beperkingen van deze techniek lijken voornamelijk van anatomische aard: de vaat en zenuwvoorziening van de getransponeerde spier dienen intact te zijn en de darm dient geheel orngeven te zijn door spierweefsel. Deze twee factoren lijken belangrijk. 
In hoofdstuk 3 worden experimenten beschreven waarin werd geprobeerd een continent stoma te construeren in een dier model. De anatomie van de buikwand werd daarom bestudeerd in 3 menselijke kadavers. Het leek mogelijk de musculus rectus te transponeren als een nieuwe sluitspier. De uitvoerbaarheid werd getoetst in 6 varkens. Drie verschillende chirurgische technieken werden getoetst. Ten eerste werd de proximale rectus als een ring rond een Thiry Vella loop gepositioneerd waardoor de spier gedeeltelijk werd gedenerveerd, voorts werd het distale uiteinde van de Thiry Vella loop door de rectus heen gepositioneerd hetgeen een partiële denervatie van de spier veroorzaakte en tenslotte werd de distale rectus als een lus gepositioneerd waarbij de zenuwen van de spier intact bleven. In 4 van deze 6 varkens werd aan beide zijde exact dezelfde chirurgische procedure toegepast. De rechter neosfincters werden elektrisch gestimuleerd met $25 \mathrm{~Hz}$ en de linker neosfincters met $2 \mathrm{~Hz}$. Elektrische stimulatie met 25 en $2 \mathrm{~Hz}$ verhoogde het percentage type I vezels die in staat zijn tot langdurige contracties significant van 42 naar $65 \%$ in de rechter en van 50 naar $67 \%$ in de linker rectus abdominis in de spierdelen die hun innervatie na de operatie behielden. Indien de Thiry Vella loop met water werd geïnfundeerd waren de neosfincters niet in staat de "flow" te stoppen. Dit werd veroorzaakt doordat de constructie van een ring en het splijten van de rectus atrofie van deze spier induceerden. Constructie van een lus veroorzaakte geen atrofie maar continentie werd niet bereikt omdat het dorsale deel van de Thiry-Vella loop niet met spiervezels was bedekt.

In hoofdstuk 4 wordt een model beschreven om continentie te bestuderen in honden. In elke hond werden beide sartorius spieren vrij geprepareerd en als nieuwe sluitspieren rond een Thiry Vella loop gepositioneerd met intacte neurovasculaire bundel. In beide spieren werden intramusculaire elektroden gepositioneerd. De elektrodenkabels werden verbonden met een elektrische stimulator die preperitoneaal werd geïmplanteerd. Bij 5 honden werd een van deze neosfincters elektrisch gestimuleerd terwijl de andere als controle diende. De "Thiry Vella loop" werd met water van een hoogte van $85 \mathrm{~cm}$ geïnfundeerd. Met de elektrische stimulator "uit" was er een ongestoorde "flow" door de Thiry-Vella loop. De gemiddelde retentietijden toonden een significante toename in de elektrisch gestimuleerde spier: van 18 (vór stimulatie) naar $308 \mathrm{sec}$. na elektrische stimulatie (gemiddelde toename $290 \mathrm{sec} ; 95 \% \mathrm{BI}: 102-478 ; \mathrm{N}=5, \mathrm{P}<0.05$ ). Het percentage type-I vezels dat in staat is tot langdurige contracties nam toe: van 48 (vóor stimulatie) naar $84 \%$ na elektrische stimulatie. Het percentage type-I vezels bleef gelijk in de controle spier. 
Indien elektrische stimulatie van een spier continu plaatsvindt zal een verandering optreden van type-II, relatief snel vermoeide vezels optreden naar type-I vezels die in staat zijn tot langdurige contracties. Daardoor wordt in de gestimuleerde sartorius van de hond een histologisch beeld geïnduceerd dat lijkt op dat van de exteme anale sfincter bij de mens.

In hoofdstuk 5 wordt beschreven hoe de waarde van de anale dynamische gracilisplastiek werd getoetst in een prospectief onderzoek bij 33 patiënten met een dusdanige fecale incontinentie dat de enige andere behandeling zou moeten bestaan uit het aanleggen van een stoma. De dynamische gracilisplastiek bestaat uit transpositie van de $\mathbf{M}$. gracilis naar het gebied rond het anale kanal en elektrische stimulatie van deze spier. De resultaten werden beoordeeld aan de hand van het klinische beloop, anale manometrie en histologisch onderzoek van de M. gracilis. Na een mediane follow-up van 10 maanden ( 8 weken- 6 jaar) waren 21 patiënten $(64 \%)$ geheel continent terwijl bij 1 patiënt het stoma (dat eerder geconstrueerd was) gesloten kan worden. Manometrie toonde een significante toename van de anale druk: van $38 \mathrm{mmHg}$ zonder stimulatie naar 59 mmHg met elektrische stimulatie (gemiddelde toename $22 \mathrm{mmHg} 95 \%$-BI: $15-29 ; n=33, p<0.01$ ). Histologisch onderzoek van de gestimuleerde $M$. gracilis toonde een significante toename van het percentage relatief goed tegen vermoeidheid resistente type I-spiervezels: van 46 (vóór stimulatie) naar $64 \%$ na elektrische stimulatie (gemiddelde toename $18 \%[13,23] n=9, p<0.01$ ). Het uitblijven van succes werd voomamelijk veroorzaakt door infecties na implantatie van de elektroden en de elektrische stimulator en het niet contraheren van de $\mathbf{M}$. gracilis rond het anale kanaal. Het lijkt mogelijk het succes van de procedure te vergroten door een vereenvoudiging van de elektroden en elektrische stimulator en een zorgvuldige dissectie en transpositie van de M. gracilis. Voordat de procedure op een uitgebreide schaal kan worden toegepast lijkt het noodzakelijk de elektrische stimulatie programma's en telemetrie procedures te vereenvoudigen. Op basis van de beschreven resultaten mag verwacht worden dat door de toepassing van de dynamische $\mathrm{M}$. gracilis het aanleggen van een stoma bij een groot aantal patiënten met fecale incontinentie kan worden vermeden. 


\section{Acknowledgements}

The results which are described in this thesis could not have been accomplished without the contributions of many others. It is impossible to thank everybody personally but I would like to express my gratitude to the following persons;

Dr. Cor Baeten, you initiated the research which has been described in this thesis. Without your enthusiasm and continuous support the work would never have been completed. Moreover, you gently introduced me into clinical and experimental surgery in your own characteristic way. I am specially grateful to you.

Prof. dr. Peter Soeters, you provided back-up. I specially appreciate your stimulation to write a thesis instead of copying some of our articles.

Prof. dr. Frank Spaans, you kindly introduced me into clinical neurophysiology. The neurophysiological examinations which were performed at your department were invaluable for the treatment of patients with faecal incontinence. I appreciate the dedication of your staff and laboratory technicians.

Dr. Miek Havenith, you showed me the principles of immunohistochemistry. Your interest and enthusiasm has contributed significantly to this thesis. In addition, I am extremely grateful to the technicians of the Department of Pathology who did the staining of all morphological sections.

Ton van den Bogaard (VDM), you assisted me (if necessary 24 hours a day) with the animal experiments. I am rateful to the cooperation of your personnel of the Centralized Animal Facilities (May, Yoyce, Peter and Frans)

Dr. Henk van Mameren, you introduced me into anatomical research and helped me with the anatomical studies.

Dr. Mick Deutz and dr. Wim Buurman, you introduced and supported me in the surgical laboratory.

Dr. Pim Versluis en dr. Kian Oei, your department collaborated in the radiological studies. Your enthusiasm was of support.

Prof. dr. Dirk Gouma, you introduced me as a medical student into research. You were a fine tutor.

Dr. Erik Heineman, you focused my aftention to the paediatric incontinent patients. The latter was a stimulant for our research activities.

The nursing staff of the outpatients' clinic sheduled and supported the manometry investigations.

Fons Habets and Vincent Schouten gave technical support during the implantation procedures. 
Eddy Adang, did the quality of life studies.

Dr. Marc Bemelmans, dr. Maarten Bouma, dr. Ivo Blaauw, we had the privilege to work in new research facilities. I appreciated your support.

Prof. Dr. Janknegt, Prof. dr. Arends, Prof. dr. Cavina, dr. Kuypers, Prof, dr. Stockbrügger and Prof. dr. Williams reviewed the final version of this thesis.

The Department of Surgery (head prof. dr. G. Kootstra) and my colleges provided an atmosphere in which the research described in this thesis could be performed.

My family and friends for their support and confidence

Thank you all! 


\section{Curriculum vitae}

The author was bom in Heerlen, The Netherlands on April 1, 1963. He attended grammar school in Heerlen (Coriovallum College, Atheneum) and attended the Utrecht University to study Pharmacy (1981-1982). He went to Medical School at Limburg University and graduated in September 1988. From October 1988 to January 1990 he served as a medical officer in the Royal Dutch Army. From January to September 1990 he worked as a resident in surgery at the Maastricht University Hospital (Head Prof. dr. G. Kootstra). At present he is a research fellow at the department of surgery in the same hospital. 
